Prepared in cooperation with the National Park Service

\title{
Assessment of Geochemical and Hydrologic Conditions near Old Yuma Mine in Saguaro National Park, Arizona, 2014-17
}

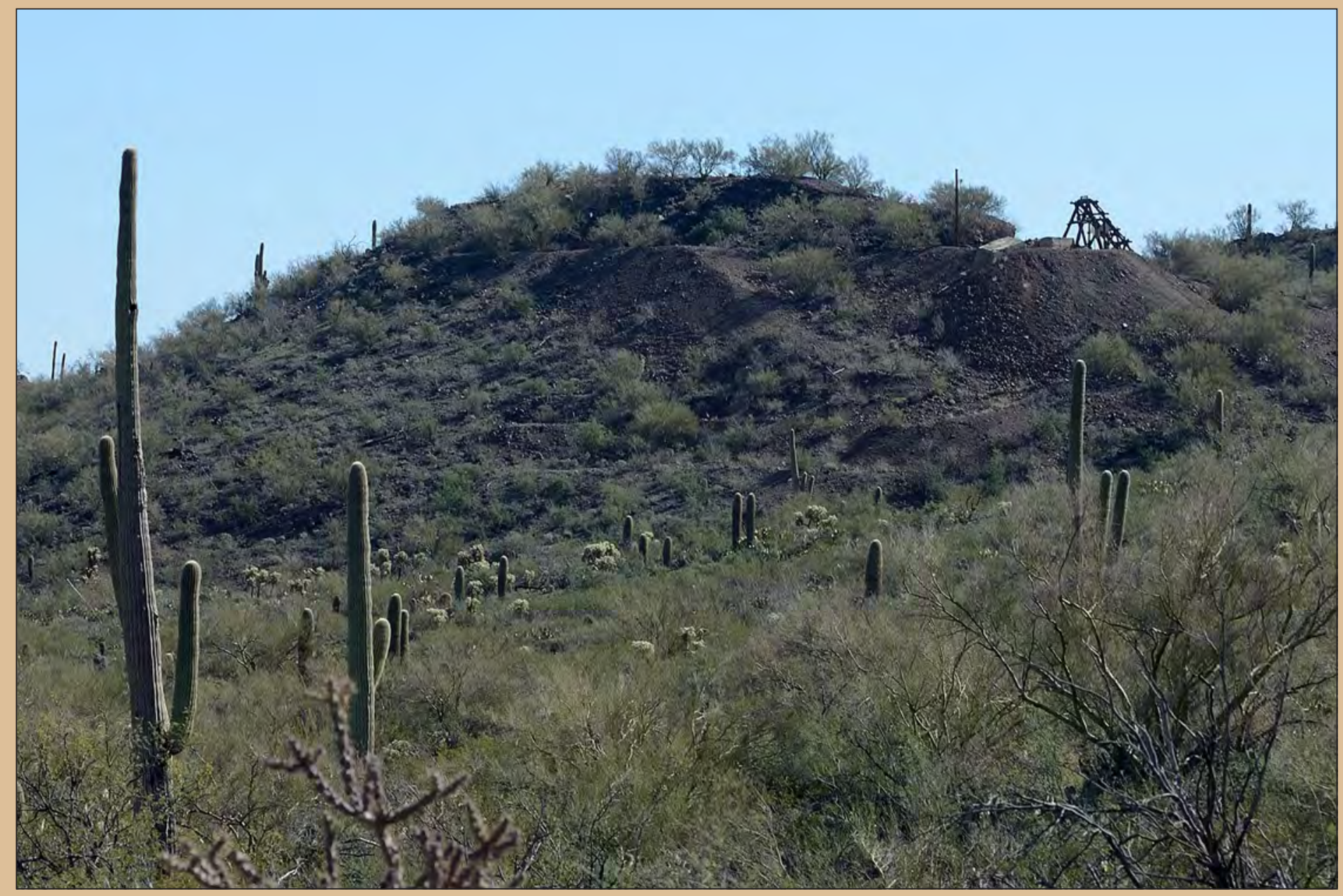

Scientific Investigations Report 2018-5019 
Cover. Remnants of Old Yuma Mine, Saguaro National Park, Arizona. U.S. Geological Survey photograph by Kimberly Beisner. 


\section{Assessment of Geochemical and Hydrologic Conditions near Old Yuma Mine in Saguaro National Park, Arizona, 2014-17}

By Kimberly R. Beisner and Floyd Gray

Prepared in cooperation with the National Park Service

Scientific Investigations Report 2018-5019 


\title{
U.S. Department of the Interior \\ RYAN K. ZINKE, Secretary
}

\section{U.S. Geological Survey William H. Werkheiser, Deputy Director exercising the authority of the Director}

\author{
U.S. Geological Survey, Reston, Virginia: 2018
}

For more information on the USGS - the Federal source for science about the Earth, its natural and living resources, natural hazards, and the environment-visit https://www.usgs.gov or call 1-888-ASK-USGS.

For an overview of USGS information products, including maps, imagery, and publications, visit https://store.usgs.gov.

Any use of trade, firm, or product names is for descriptive purposes only and does not imply endorsement by the U.S. Government.

Although this information product, for the most part, is in the public domain, it also may contain copyrighted materials as noted in the text. Permission to reproduce copyrighted items must be secured from the copyright owner.

Suggested citation:

Beisner, K.R., and Gray, F., 2018, Assessment of geochemical and hydrologic conditions near Old Yuma Mine in Saguaro National Park, Arizona, 2014-17: U.S. Geological Survey Scientific Investigations Report 2018-5019, 52 p., https://doi.org/10.3133/sir20185019.

ISSN 2328-0328 (online) 


\section{Acknowledgments}

This study was made possible by the gracious contributions of well owners in the Old Yuma Mine area who facilitated field personnel making water-level measurements and collecting groundwater samples. Saguaro National Park provided invaluable information and support. 


\section{Contents}

Acknowledgments …....................................................................................................................ii

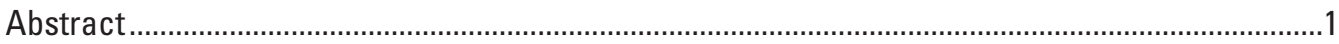

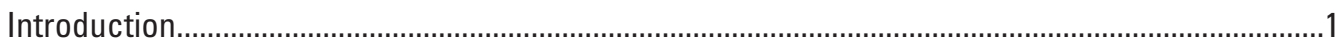

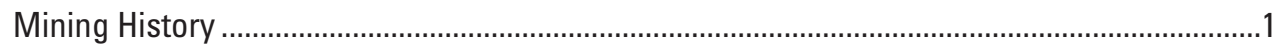

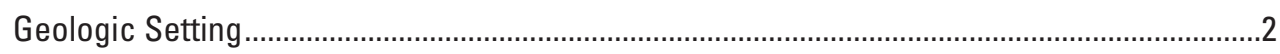

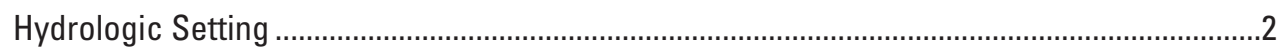

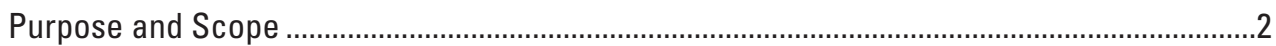

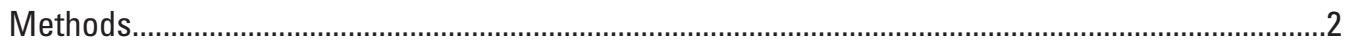

Field .

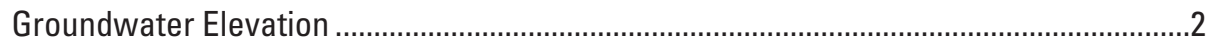

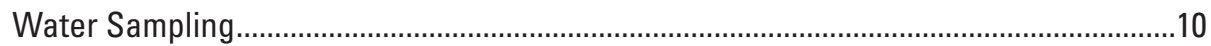

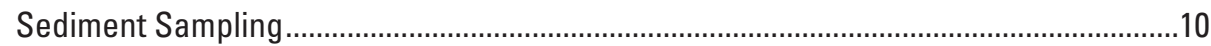

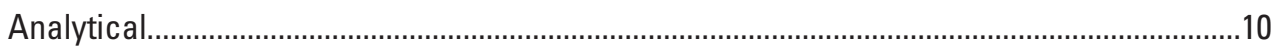

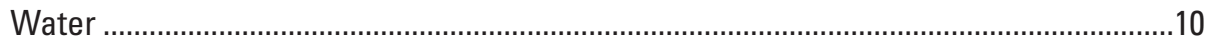

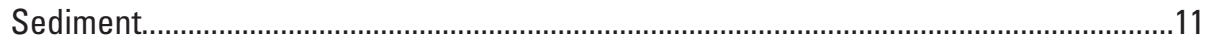

Quality Assurance Procedures ........................................................................................11

Water

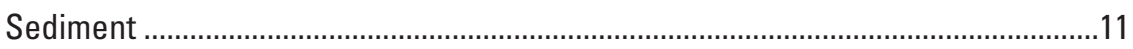

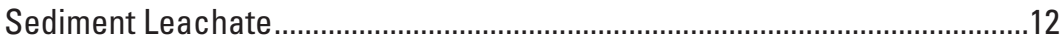

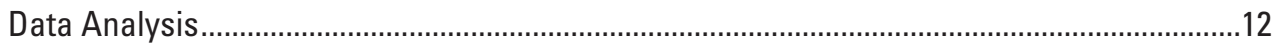

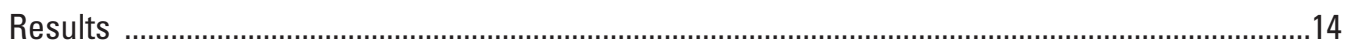

Quality Assessment ...........................................................................................................

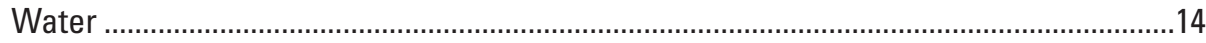

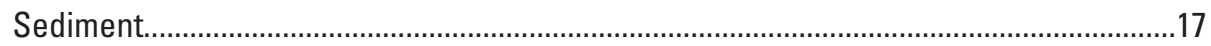

Sediment Leachate

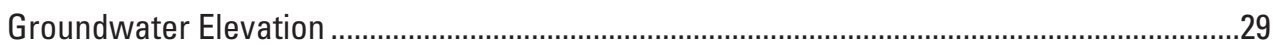

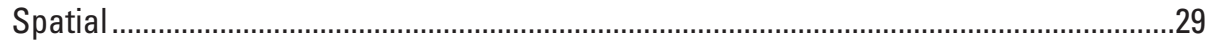

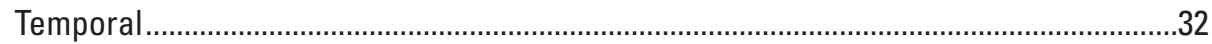

Groundwater Geochemistry...................................................................................................

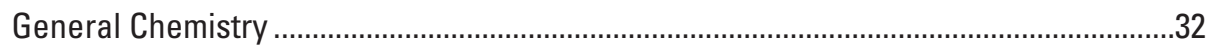

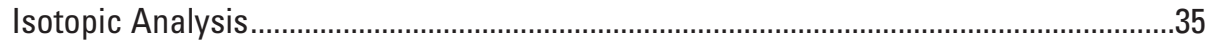

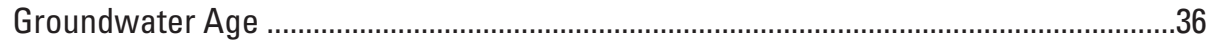

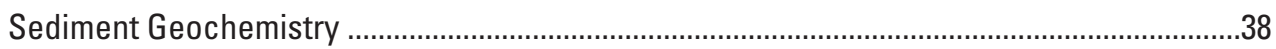

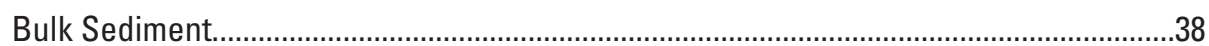

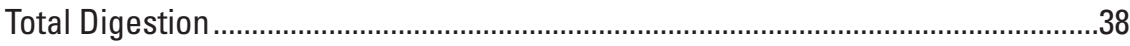

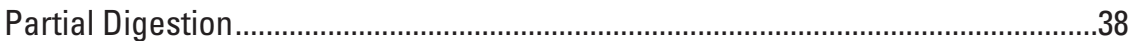

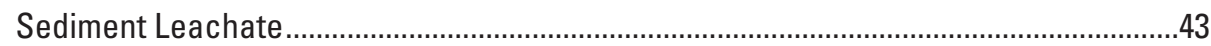

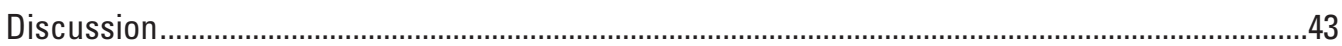

Assessment of Groundwater Compared with Sediment and Associated Leachate ...............43

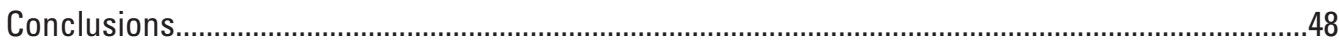

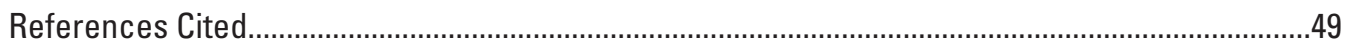

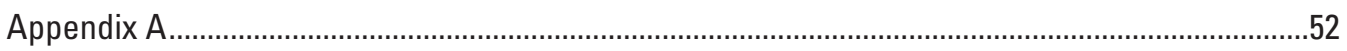




\section{Figures}

1. Map of the study area

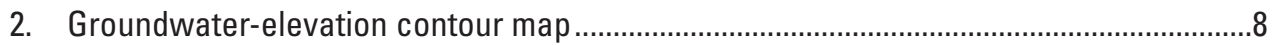

3. Groundwater level measured with a pressure transducer at two well sites ...................33

4. Piper diagram plotting the major ion proportion of groundwater samples .....................34

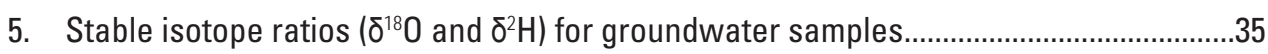

6. Stable isotope ratios $\left(\delta^{34} S\right.$ and $\left.\delta^{18} 0\right)$ for groundwater samples.....................................35

7. Strontium isotope ratio versus strontium concentration for groundwater samples.......36

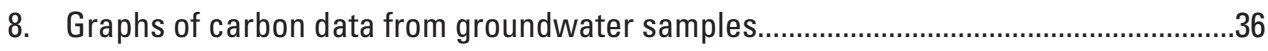

9. Boxplots of element concentrations determined for total digestion samples .................39

10. Geologic map showing sampling locations and concentrations of lead in sediment

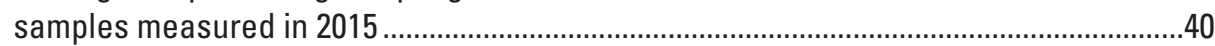

11. Graph of lead, zinc, and manganese concentrations in stream sediment samples .......41

12. Graph of lead, zinc, and manganese concentrations in background sediment samples versus distance from the Old Yuma Fault ........................................................41

13. Non-metric multidimensional scaling plot for sediment samples ....................................4

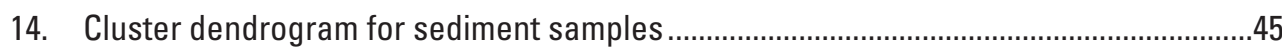

15. Non-metric multidimensional scaling plot for leachate and groundwater samples.......46

16. Cluster dendrogram for leachate and groundwater samples.......................................47

17. Strontium isotopic value versus strontium concentration for leachate samples............48

\section{Tables}

1. Groundwater-level measurement site information ........................................................6

2. U.S. Environmental Protection Agency water-quality standards for drinking water......13

3. U.S. Environmental Protection Agency and Arizona Department of Environmental

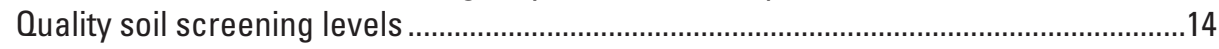

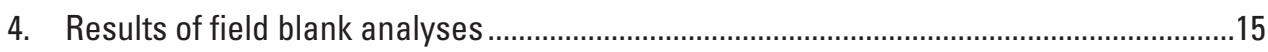

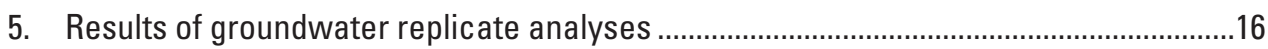

6. Field replicate sediment data for total digestion samples collected from Old

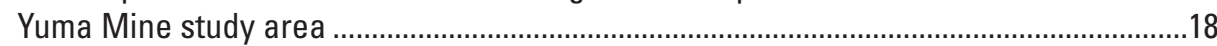

7. Laboratory replicate sediment data for total digestion samples collected from

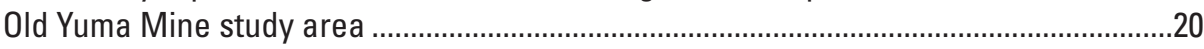

8. Field replicate sediment data for U.S. Environmental Protection Agency 3050 method partial digestion samples collected from Old Yuma Mine study area.................22

9A. Total digestion results for sediment reference materials Cody Shale (SCo-1), Green River Shale (SGR-1b), and Granodiorite (GSP-2)..

$9 B$. Total digestion results for sediment reference materials Andesite (AGV-2) and Granodiorite (GSP).

10. Sediment reference material results for U.S. Environmental Protection Agency 3050 partial digestion 
11. Results of sediment leachate replicate analyses for site OYM-14-W ............................28

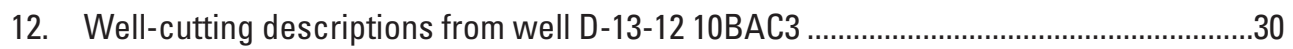

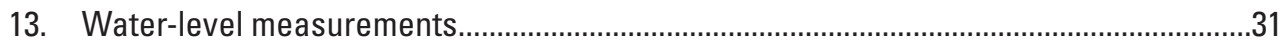

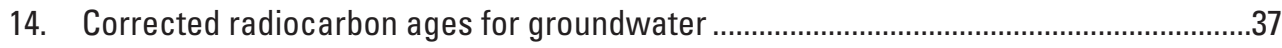

15. Dissolved gas values in groundwater samples .............................................................37

16. Concentrations of elements from background sediments near the Old Yuma Mine compared with average values from the Western United States.

\section{Conversion Factors}

U.S. customary units to International System of Units

\begin{tabular}{|c|c|c|}
\hline Multiply & By & To obtain \\
\hline \multicolumn{3}{|c|}{ Length } \\
\hline inch (in.) & 2.54 & centimeter $(\mathrm{cm})$ \\
\hline inch (in.) & 25.4 & millimeter (mm) \\
\hline foot $(\mathrm{ft})$ & 0.3048 & meter (m) \\
\hline mile (mi) & 1.609 & kilometer (km) \\
\hline yard (yd) & 0.9144 & meter $(\mathrm{m})$ \\
\hline \multicolumn{3}{|c|}{ Area } \\
\hline acre & 4,047 & square meter $\left(\mathrm{m}^{2}\right)$ \\
\hline acre & 0.4047 & hectare (ha) \\
\hline acre & 0.4047 & square hectometer $\left(\mathrm{hm}^{2}\right)$ \\
\hline acre & 0.004047 & square kilometer $\left(\mathrm{km}^{2}\right)$ \\
\hline square mile $\left(\mathrm{mi}^{2}\right)$ & 259.0 & hectare (ha) \\
\hline square yard (yd2) & 0.836127 & square meter $\left(\mathrm{m}^{2}\right)$ \\
\hline \multicolumn{3}{|c|}{ Volume } \\
\hline ounce, fluid (fl. oz) & 0.02957 & liter (L) \\
\hline pint (pt) & 0.4732 & liter (L) \\
\hline quart (qt) & 0.9464 & liter (L) \\
\hline gallon (gal) & 3.785 & liter (L) \\
\hline cubic inch (in $\left.{ }^{3}\right)$ & 0.01639 & liter (L) \\
\hline cubic yard $\left(\mathrm{yd}^{3}\right)$ & 0.7646 & cubic meter $\left(\mathrm{m}^{3}\right)$ \\
\hline \multicolumn{3}{|c|}{ Mass } \\
\hline ounce, avoirdupois (oz) & 28.35 & gram (g) \\
\hline pound, avoirdupois (lb) & 0.4536 & kilogram (kg) \\
\hline
\end{tabular}

Temperature in degrees Celsius $\left({ }^{\circ} \mathrm{C}\right)$ may be converted to degrees Fahrenheit $\left({ }^{\circ} \mathrm{F}\right)$ as follows:

$$
{ }^{\circ} \mathrm{F}=\left(1.8 \times{ }^{\circ} \mathrm{C}\right)+32 .
$$

Temperature in degrees Fahrenheit $\left({ }^{\circ} \mathrm{F}\right)$ may be converted to degrees Celsius $\left({ }^{\circ} \mathrm{C}\right)$ as follows:

$$
{ }^{\circ} \mathrm{C}=\left({ }^{\circ} \mathrm{F}-32\right) / 1.8 \text {. }
$$




\section{Datum}

Vertical coordinate information is referenced to the North American Vertical Datum of 1988 (NAVD 88).

Horizontal coordinate information is referenced to the North American Datum of 1983 (NAD 83).

Altitude, as used in this report, refers to distance above the vertical datum.

\section{Supplemental Information}

Specific conductance is given in microsiemens per centimeter at 25 degrees Celsius $\left(\mu \mathrm{S} / \mathrm{cm}\right.$ at $\left.25^{\circ} \mathrm{C}\right)$

Concentrations of chemical constituents in water are given in either milligrams per liter (mg/L) or micrograms per liter $(\mu \mathrm{g} / \mathrm{L})$.

Activities for radioactive constituents in water are given in picocuries per liter (pCi/L).

Results for measurements of stable isotopes of an element (with symbol E) in water, solids, and dissolved constituents commonly are expressed as the relative difference in the ratio of the number of the less abundant isotope ( $\mathrm{E}$ ) to the number of the more abundant isotope of a sample with respect to a measurement standard.

Note to USGS users: Use of hectare (ha) as an alternative name for square hectometer $\left(\mathrm{hm}^{2}\right)$ is restricted to the measurement of small land or water areas. Use of liter (L) as a special name for cubic decimeter $\left(\mathrm{dm}^{3}\right)$ is restricted to the measurement of liquids and gases. No prefix other than milli should be used with liter.

\section{Abbreviations}

AZDEO

BLM

CERCLA

EPA

GMWL

GPS

ICP-AES

ICP-MS

LMWL

NMDS

NOSAMS

NWQL

SGS

SPLP

TEM

USGS
Arizona Department of Environmental Quality

Bureau of Land Management

Comprehensive Environmental Response, Compensation, and Liability Act

U.S. Environmental Protection Agency

global meteoric water line

global positioning system

inductively coupled plasma atomic emission spectrometry

inductively coupled plasma mass spectrometry

local meteoric water line

non-metric multidimensional scaling

National Ocean Sciences Accelerator Mass Spectrometry

National Water Quality Laboratory

Société Générale de Surveillance (USGS contract laboratory)

synthetic precipitation leaching procedure

transient electromagnetics

U.S. Geological Survey 



\title{
Assessment of Geochemical and Hydrologic Conditions near Old Yuma Mine in Saguaro National Park, Arizona, 2014-17
}

\author{
By Kimberly R. Beisner and Floyd Gray
}

\section{Abstract}

The Old Yuma Mine is an abandoned copper, lead, zinc, silver, and gold mine located within the boundaries of Saguaro National Park, Tucson Mountain District, Arizona. This study analyzed the geochemistry of sediments associated with the Old Yuma mine and assessed hydrologic and geochemical conditions of groundwater to evaluate the area surrounding the Old Yuma Mine. The purpose of the study was to establish the geochemical signature of material associated with the Old Yuma Mine and to compare it with background material and groundwater in the area. Near the mine, groundwater generally flows to the northeast. A locally anomalous steep gradient in groundwater elevation is present beneath alluvial fan deposits in the center of the study area, near the projection of the Old Yuma Fault trend. Few groundwater samples exceeded the EPA drinking water standards. One sample exceeded the EPA primary drinking water standard for arsenic; one sample exceeded the EPA secondary drinking water standard for chloride, iron, and manganese and two other samples exceeded the total dissolved solids secondary drinking water standard. Analysis of groundwater age indicates groundwater with a component of modern water is present on the northwest side of the study area. Groundwater on the southeast side of the study area is primarily older, with a radiocarbon age ranging from approximately 600 to 6,700 years before present.

Concentrations of several elements (As, Bi, Cd, Co, $\mathrm{Cu}, \mathrm{Fe}, \mathrm{Hg}, \mathrm{In}, \mathrm{Li}, \mathrm{Mn}, \mathrm{Mo}, \mathrm{Pb}, \mathrm{Sb}, \mathrm{U}, \mathrm{V}, \mathrm{W}$, and $\mathrm{Zn}$ ) were elevated in the waste rock and mine tailings compared with concentrations in sediments collected in background areas. Concentrations of four elements (As, Mo, Pb, and V) in some sediment samples were greater than the EPA regional soil screening levels and (or) Arizona Department of Environmental Quality (AZDEQ) soil screening levels. A subset of 15 sediment samples was leached according to the EPA 1312 leachate method to simulate precipitation interacting with the solid material. The $\mathrm{pH}$ of the leachate samples increased following the leaching procedure. Several leachate samples had concentrations that exceeded the EPA drinking water standards for As, Mn, and $\mathrm{Pb}$. Analysis of leachate samples compared to groundwater samples suggests that groundwater samples collected in this study are similar to each other and distinct from leachate samples associated with mining related material. Results suggest that at this time groundwater samples collected during this investigation are not influenced by elements leached from Old Yuma Mine materials.

\section{Introduction}

Saguaro National Park consists of two districts, the Rincon Mountain District and Tucson Mountain District on the far eastern and western sides, respectively, of the city of Tucson, Arizona (fig. 1). The Tucson Mountain District historically experienced gold and silver mining activity from 1880 to the 1970 s and in 1994 Saguaro National Park acquired one of these mines, the Old Yuma Mine. The Old Yuma Mine was active from the dawn of the twentieth century through World War I, and produced steel-hardening minerals such as wulfenite, molybdenite, and vanadinite, and the base and precious metals lead, copper, zinc, silver, and gold (National Park Service, 2010).

\section{Mining History}

Located on a fault that trends east-northeast and dips steeply to the southeast, the Old Yuma Mine contains a relatively wide lenticular surface expression and a 300-foot (ft) inclined shaft that dips at an angle of $43^{\circ}$ and provides access to its underground workings (Wilson and Schlepp, 2008). Horizontal underground workings occur at the 65-, 100-, 200-, and 300-ft levels off the main incline. Between 1916 and 1947, this underground mine produced 5,700 tons of ore grading 4 percent lead, 1 percent copper, 0.6 percent zinc, 0.3 percent molybdenum, 1 ounce silver per ton, and 0.1 ounce gold per ton. This mine also produced high quality specimens of wulfenite $\left(\mathrm{PbMoO}_{4}\right)$, a lead-molybdenum oxide, and vanadinite $\left(\mathrm{Pb}_{5}\left(\mathrm{VO}_{4}\right)_{3} \mathrm{Cl}\right)$, a lead-vanadium mineral. 
The first claim to the Old Yuma Mine was filed in 1885, and a mill capable of handling 100 tons per day was constructed on site in 1916 for concentrating gold, molybdenum, and vanadium (Wilson and Schlepp, 2008). The mine changed ownership in 1930 and occasionally produced dump ore and surface material, but the mine was primarily used for acquiring mineral specimens. Around 1969, the ceiling of the main mine incline shaft caved in and large slabs of rock fell in single pieces.

In addition to waste rock located around the property, approximately 7,000 cubic yards of tailings remain stockpiled at the Old Yuma Mine site, though this is only part of the original tailings pile. The remainder of the pile was used for road base in the surrounding area (Michael Baker Jr., Inc., 2005). The current mine site includes a large inclined excavation open to the surface, shafts (inclined and vertical), adits (nearly horizontal passageways into the mine), a headframe that was used to hoist the inclined main access shaft, a concrete mill foundation, a solid waste dumping area, and a small leach pad. The leach pad was constructed in 1984 for the purpose of reducing gold ore from the remnant mine tailings, but it was never operational (Michael Baker Jr., Inc., 2005).

A local claimant, Richard A. Bideaux, received a patent on the valid claims from the Bureau of Land Management (BLM) near the time the land transferred from BLM to National Park Service management in 1994 (Comet 1 Lode, Old Yuma \#1 Lode, and Old Yuma Placer Mining Claims, which were top-staked on one another and occupied a total of about 22 acres [9 hectares]). Saguaro National Park's primary concern regarding this mine is potential injury owing to onsite hazards (National Park Service, 2010). Old Yuma Mine is currently under a Comprehensive Environmental Response, Compensation, and Liability Act (CERCLA, or "Superfund") investigation (National Park Service, 2010).

\section{Geologic Setting}

The Tucson Mountains, in which the Old Yuma Mine is located, are underlain by Late Cretaceous volcanic rocks interpreted as part of the fill of a large ash-flow caldera (Lipman, 1993). Volcanic rocks of the Old Yuma Mine area consist of compositionally diverse lava flows, intrusive dikes, and interleaved sedimentary rocks. Rock units around the Old Yuma Mine are described as aphanitic andesite [Kya] and aphanitic rhyolite and dacite flows [Kyr] (Lipman, 1993). Aphanitic andesite consists of dark-gray, fine-grained andesitic lava flows containing 20-40 percent small phenocrysts of plagioclase, augite, and serpentine pseudomorphs after olivine or orthopyroxene. Aphanitic rhyolite and dacite flows are described as tan to light-gray lava flows containing minor small phenocrysts of sanidine, plagioclase, and recrystallized biotite (Lipman, 1993).

The ore deposit at the Old Yuma Mine consists of a porphyritic andesite or latite dike occupying a dip-slip fault dipping at about $43^{\circ}$ through Cretaceous andesite (Wilson and
Schlepp, 2008). The average width of the dike is $8-10 \mathrm{ft}$, but widens to $20 \mathrm{ft}$ on the $65-\mathrm{ft}$ level. The dike contains scattered pods of silver-rich galena altered to anglesite and cerussite, which released lead for the crystallization of vanadinite and wulfenite. Vanadinite and wulfenite occur in distinct zones and were reported to be milled in separate bins; wulfenite is found primarily on the western part of the fissure and vanadinite on the eastern part (Wilson and Schlepp, 2008).

\section{Hydrologic Setting}

No perennial surface water features exist in the study area, but ephemeral washes are present that flow episodically following precipitation events. Groundwater is present in the study area generally as part of fractured bedrock, alluvium, and alluvial fan deposits.

\section{Purpose and Scope}

Updated information on groundwater levels in the Old Yuma Mine area and chemistry of mining-related materials and groundwater are needed by Saguaro National Park for a better understanding of the presence and quality of groundwater near the Old Yuma Mine. This report (1) presents a groundwater surface elevation map to estimate the groundwater elevation below the Old Yuma Mine; (2) characterizes the chemistry of mining-related material, background sediment, and water leached from both of these materials; and (3) compares leachate chemistry to groundwater chemistry from the surrounding area. The study area includes groundwater wells located south of Ina Road, north of Camino del Cerro Road, west of Silverbell Road and east of Golden Gate Road (fig. 1).

\section{Methods}

\section{Field}

\section{Groundwater Elevation}

Groundwater-level measurements were collected from 29 sites throughout the study area between December 2014 and February 2017 (table 1; fig. 2). Twenty of the sites were domestic wells that were in use during the study period, and measurements at these sites represent recently pumped water levels. Eight of the sites were wells that are no longer in use, and measurements at these sites represent static water levels. One site was an abandoned mine shaft that has standing water at the bottom. 

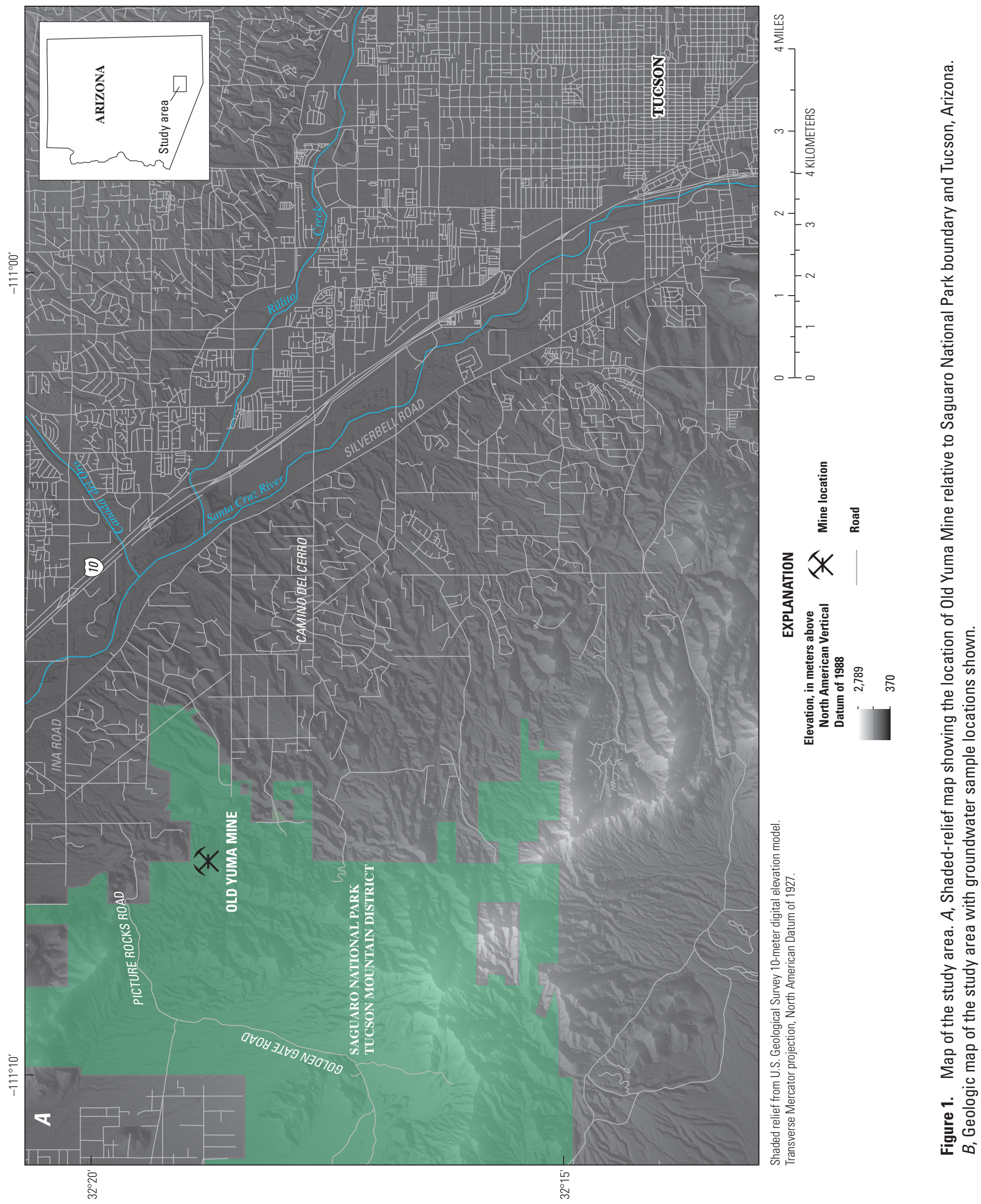


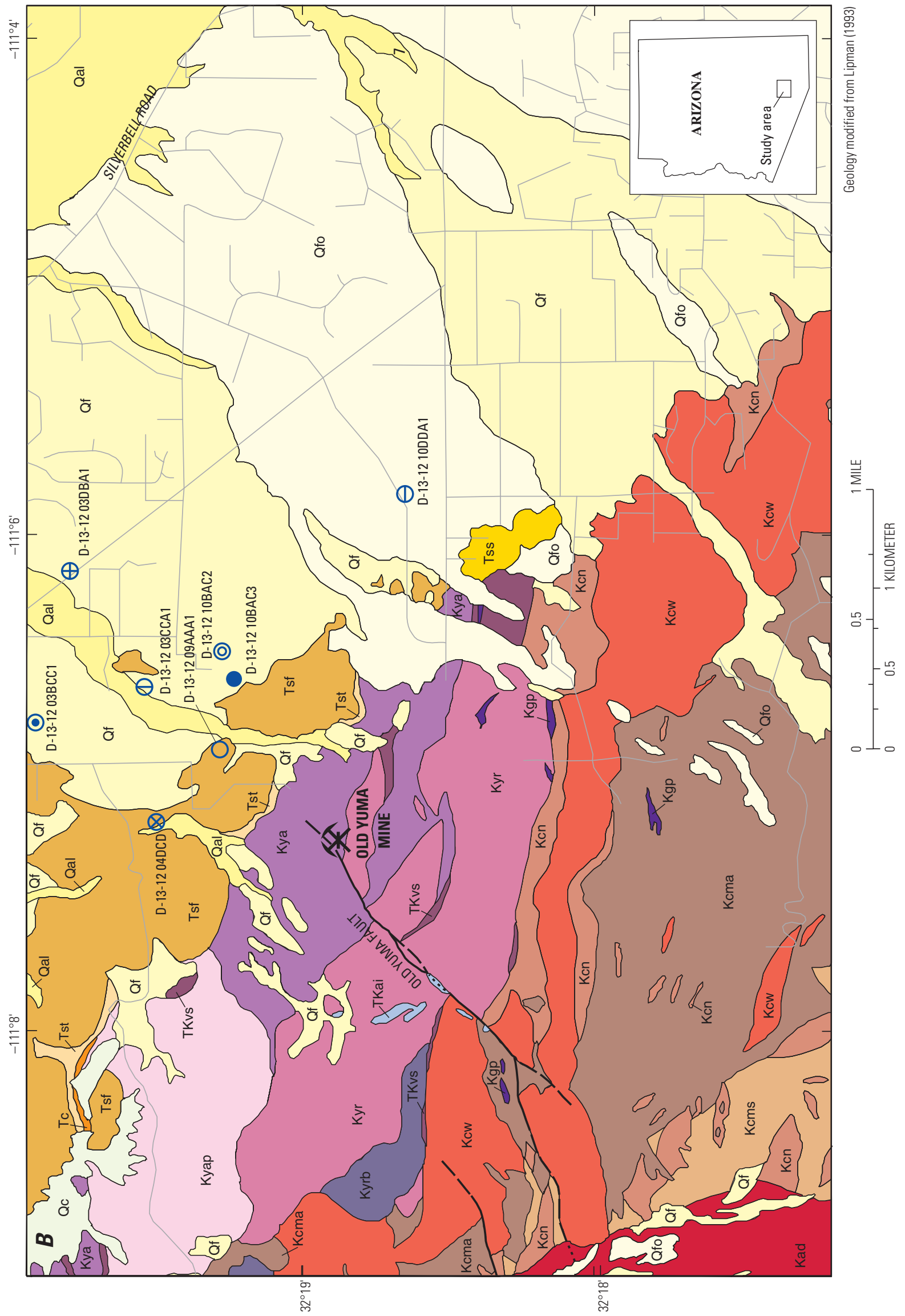

1. 

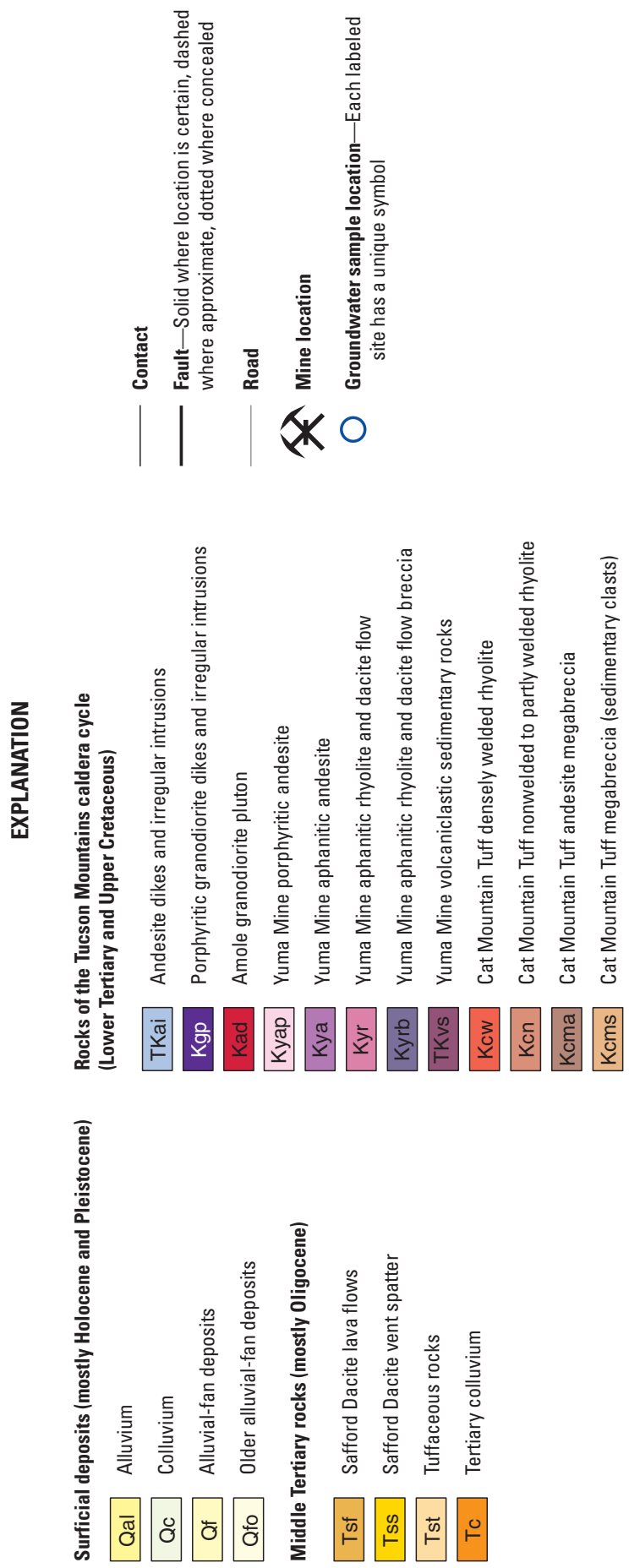


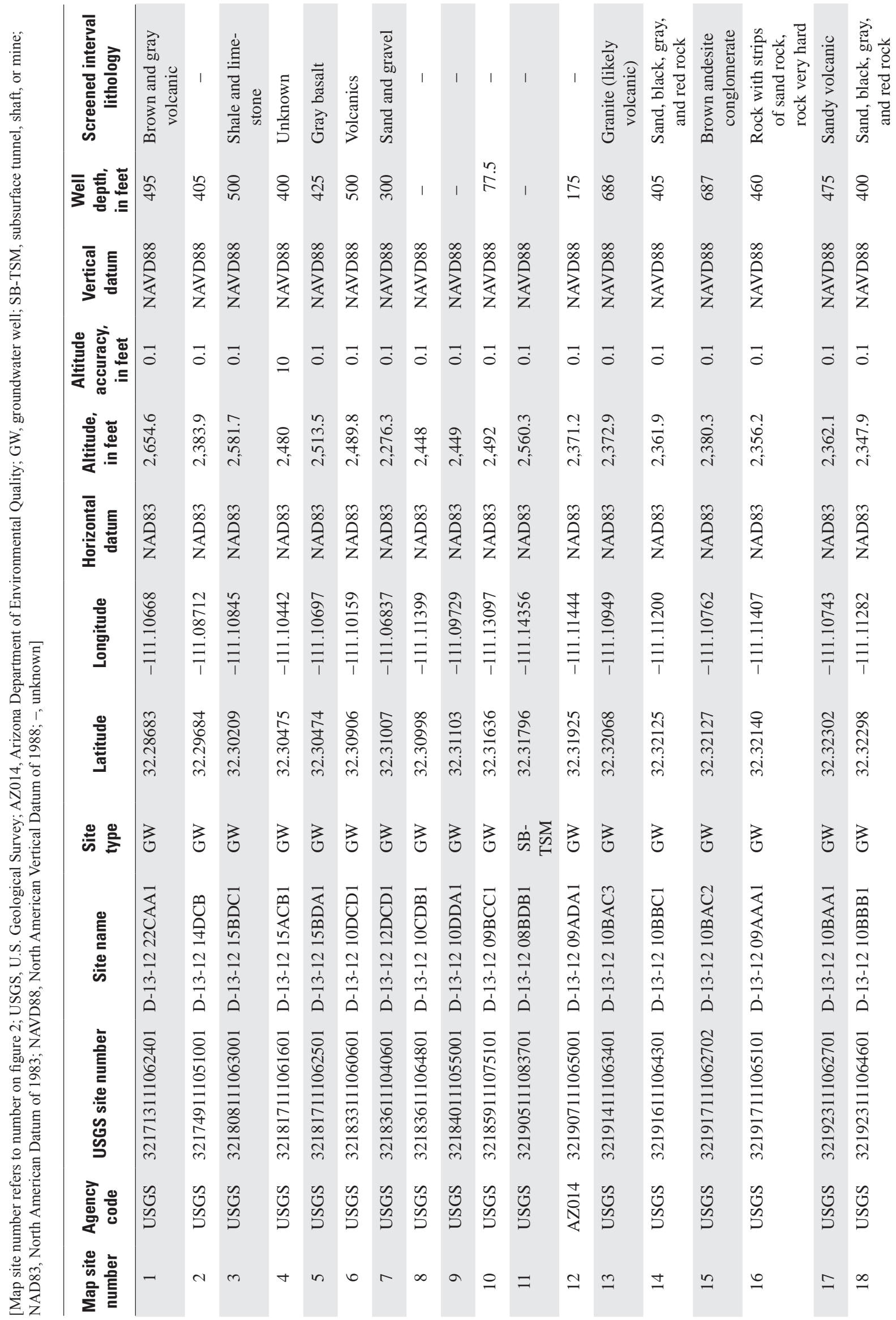




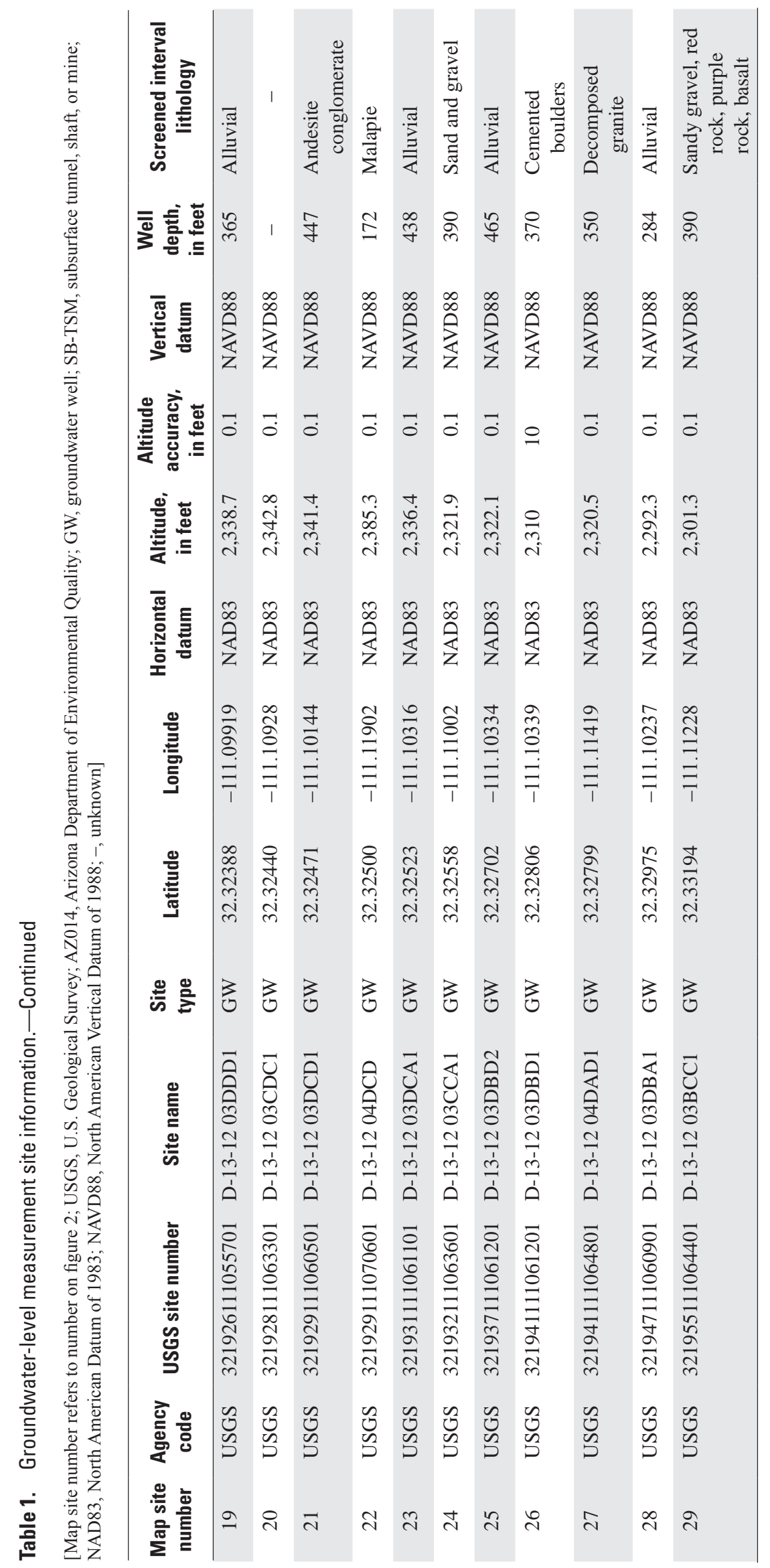



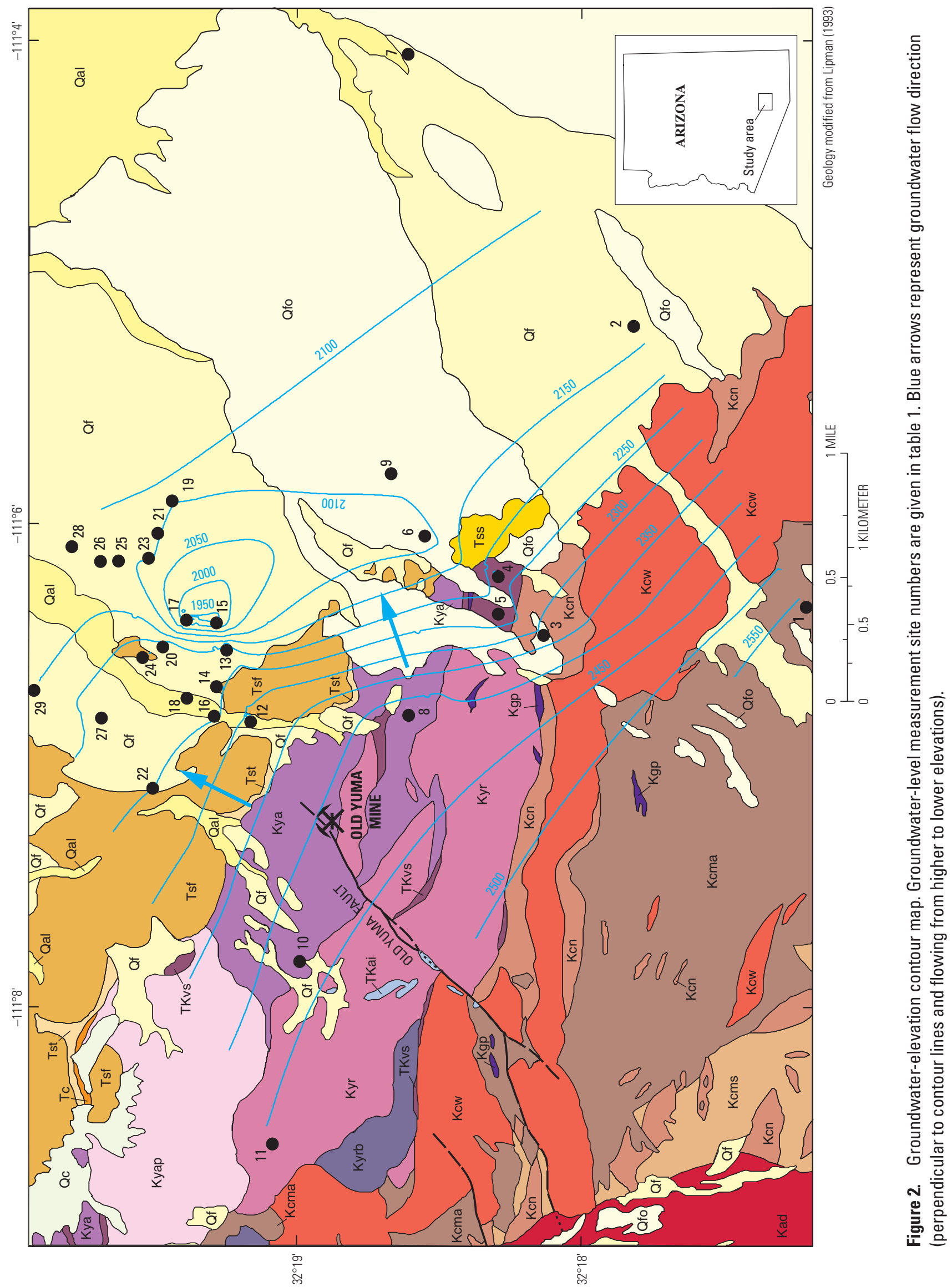

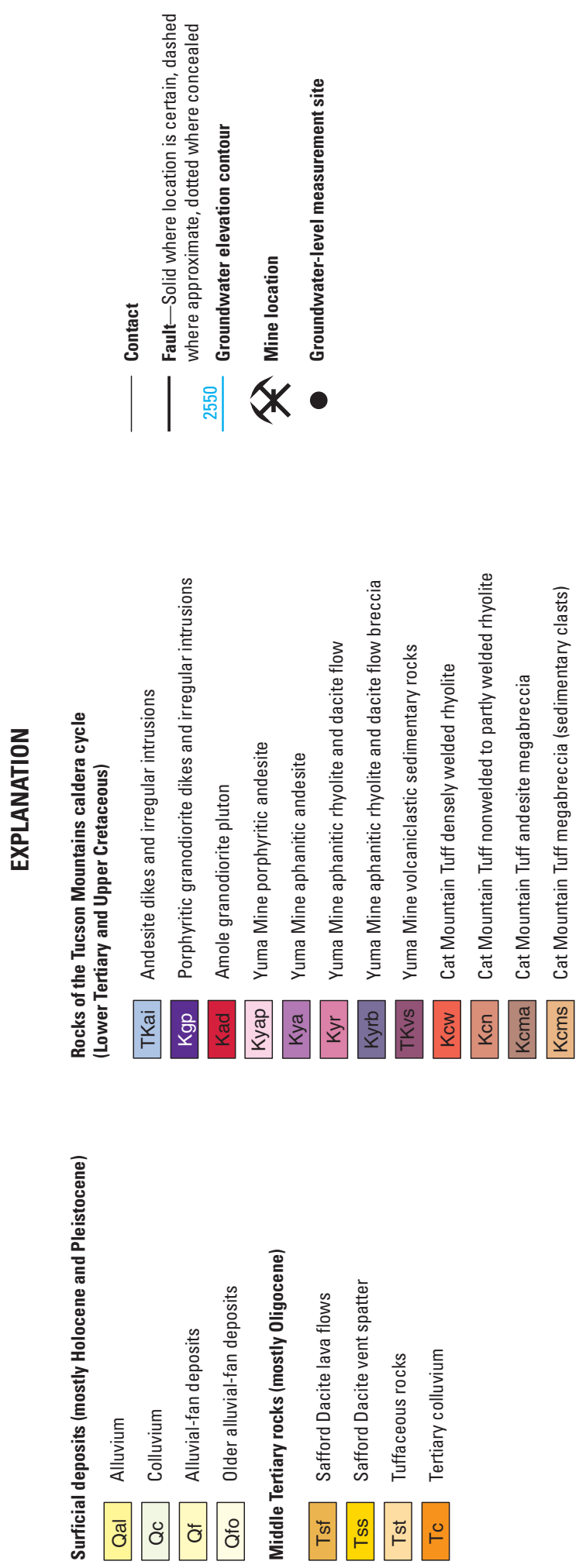
Precise Trimble differential global positioning system (GPS) was used to make the GPS measurements at all sites. Groundwater elevation was calculated by subtracting the water-level measurement below the land surface from the land surface elevation at each site. For sites with more than one water-level measurement, the average of the measurements was used. Groundwater elevation data were contoured in ArcMap 10.5 using natural neighbor interpolation and some minor manual edits.

\section{Water Sampling}

Groundwater samples were collected for water-quality analyses from eight wells following standard U.S. Geological Survey (USGS) protocols (U.S. Geological Survey, variously dated; fig. 1B). Before water samples were collected, field parameters including $\mathrm{pH}$, water temperature, specific conductance, dissolved oxygen, and barometric pressure were measured in a flow-through cell during well purging at each well site. Well discharge was measured by field personnel using volumetric techniques or was reported by the owner. Water level, casing dimensions, and pumping rate were used to calculate purge volume and time required to purge three casing volumes prior to sample collection.

Water samples were filtered $(0.45$ micron, $\mu \mathrm{m})$ for major cations, trace elements, alkalinity, nutrients, ${ }^{14} \mathrm{C}$, sulfur isotopes, perchlorate, and lead and strontium isotopes. The major cations, trace elements, and lead and strontium isotope samples were preserved to $\mathrm{pH}<2$ by adding ultrapure nitric acid. Unfiltered samples were collected for tritium, stable isotopes, and sulfur hexafluoride $\left(\mathrm{SF}_{6}\right)$. Alkalinity (field) was computed from titration data using the incremental equivalence method (U.S. Geological Survey, variously dated). Dissolved gases of nitrogen and argon were collected in glass septum bottles, filled, and sealed with a rubber stopper punctured with a needle and removed underwater in a beaker. Two separate samples of dissolved gases and $\mathrm{SF}_{6}$ were collected and analyzed for each sample.

\section{Sediment Sampling}

Sediment samples were collected from 38 sites: 10 from two tailings piles; 10 from a large waste rock pile at the Old Yuma Mine site; 5 along an ephemeral drainage originating at and draining the mine site; and 13 background samples from both sides of the hill to the south of the Old Yuma Mine site. At each site, field technicians collected samples by delineating a 1-square-yard area, and then compositing 10 evenly spaced scoops of soil within each area into a plastic bag. A plastic garden scoop was used to collect soil samples including the top layer and $~ 2$ inches below the surface, and the scoop was cleaned with deionized water between each sample location. Sediment samples were passed through a 2-millimeter sieve before analysis. Sediment samples use the naming convention OYM-04-T, for example, where the number refers to the sediment sample sequence number and the ending letter refers to the sample type. Samples were numbered sequentially by collection time and assigned one of the following letters: $\mathrm{T}$ for tailings, $\mathrm{W}$ for waste rock, $\mathrm{S}$ for stream sediment, or B for background.

\section{Analytical Water}

Water samples were analyzed for major cations, trace elements, and nutrients by the USGS National Water Quality Laboratory (NWQL). Analytical methods from the USGS NWQL included inductively coupled plasma mass spectrometry (ICP-MS) to determine concentrations of $\mathrm{Al}$, $\mathrm{Sb}, \mathrm{As}, \mathrm{Ba}, \mathrm{Be}, \mathrm{B}, \mathrm{Cd}, \mathrm{Cr}, \mathrm{Co}, \mathrm{Cu}, \mathrm{Pb}$, Li, Mo, Ni, Se, Ag, Sr, Tl, W, U, V, and Zn (Garbarino and others, 2006). Inductively coupled plasma atomic emission spectrometry (ICP-AES) was used to analyze for $\mathrm{Ca}, \mathrm{Fe}, \mathrm{K}, \mathrm{Mg}, \mathrm{Mn}$, and $\mathrm{Na}$ (Fishman, 1993). Anions $\mathrm{Cl}^{-}, \mathrm{F}^{-}$, and $\left(\mathrm{SO}_{4}\right)^{2-}$ were analyzed by ion chromatography and $\mathrm{SiO}_{2}$ was analyzed by discrete analyzer colorimetry (Fishman and Friedman, 1989). Nitrate $\left(\mathrm{NO}_{3}\right)$ plus nitrite $\left(\mathrm{NO}_{2}\right)$ were analyzed by colorimetry (Patton and Kryskalla, 2011). Perchlorate $\left(\mathrm{ClO}_{4}\right)^{-}$was analyzed by Weck Laboratories, Inc.

Stable isotope ratios $\left(\delta^{18} \mathrm{O}\right.$ and $\left.\delta^{2} \mathrm{H}\right)$ were measured at the USGS Reston Stable Isotope Laboratory following methods by Révész and Coplen (2008a, b). The 2-sigma uncertainties for the stable isotope analyses are 0.2 per mil for $\delta^{18} \mathrm{O}$ and 2 per mil for $\delta^{2} \mathrm{H}$, reported relative to Vienna standard mean ocean water. The Reston Stable Isotope Laboratory measured $\delta^{34} \mathrm{~S}$ of sulfate following methods by Révész and others (2012).

The USGS National Research Program Laboratory in Menlo Park, Calif., measured strontium isotope ratios $\left({ }^{87} \mathrm{Sr} /{ }^{86} \mathrm{Sr}\right)$ using methods described in Bullen and others (1996). These methods are precise to 0.00002 or better at the 95-percent confidence level.

${ }^{14} \mathrm{C}$ and $\delta^{13} \mathrm{C}$ ratios were analyzed by the National Ocean Sciences Accelerator Mass Spectrometry (NOSAMS) at Woods Hole Oceanographic Institution. ${ }^{14} \mathrm{C}$ values (reported by NOSAMS as absolute percent modern carbon) were denormalized using equation 5 of Plummer and others (2012) to percent modern carbon (pmc). NetpathXL computed corrected groundwater ages using model 11 "Revised F\&G solid ex" (Parkhurst and Charlton, 2008). Groundwater age was computed with ${ }^{14} \mathrm{C}$ values of 0 and 10 pmc for carbonate rock and 100 pmc for soil $\mathrm{CO}_{2}$, assuming $\delta^{13} \mathrm{C}$ values of -4.5 per mil for carbonate and -19.1 per mil for soil $\mathrm{CO}_{2}$ (Kalin, 1994). The University of Miami Tritium Laboratory measured tritium using the electrolytic enrichment and gas counting method, with a reporting limit of 0.3 picocuries per liter $(\mathrm{pCi} / \mathrm{L})$. 
Dissolved gases of nitrogen and argon were analyzed at the USGS Groundwater Dating Laboratory by methods documented in U.S. Geological Survey (2017a), which are summarized below. The lab analyzed the samples using a Hewlett Packard model 7890B gas chromatograph with helium as the carrier gas. The headspace gas pressure was measured with a pressure transducer. The sample gas was then introduced simultaneously into two sampling loops. One sampling loop was injected into an Alltech CTR-III column at $55^{\circ} \mathrm{C}$ to separate argon, nitrogen, and oxygen. These gases were quantified with a thermal conductivity detector. The second sampling loop was injected into an Alltech CTR-I column at $30^{\circ} \mathrm{C}$ to separate methane $\left(\mathrm{CH}_{4}\right)$ and carbon dioxide $\left(\mathrm{CO}_{2}\right)$ from the other constituents. After separation, the gas stream was passed through a nickel methanizer converting $\mathrm{CO}_{2}$ to $\mathrm{CH}_{4}$ and the two gases were quantified with a flame ionization detector. The gas chromatograph was calibrated with four gravimetric gas standards and one National Oceanic and Atmospheric Administration air standard at the beginning of each day and checked again at the end of each day. Instrument drift was generally less than 1 percent for argon, nitrogen, and oxygen (Ar, $\mathrm{N}_{2}$, and $\mathrm{O}_{2}$ ) and 1-2 percent for $\mathrm{CH}_{4}$ and $\mathrm{CO}_{2}$.

The USGS Groundwater Dating Laboratory also analyzed $\mathrm{SF}_{6}$ samples, using a purge and trap gas chromatography procedure with an electron capture detector and following the methods summarized below (U.S. Geological Survey, 2017a). The apparatus used for vacuum extraction of $\mathrm{SF}_{6}$ from groundwater is similar to the system described by Law and others (1994) and Busenberg and Plummer (2000). The apparatus consists of a 950-milliliter glass stripping vessel and various valves that control the vacuum and the flow of gases and water. For water samples, the stripped gas is trapped on a large trap immersed in an isopropyl alcohol-dry ice bath at about $-70{ }^{\circ} \mathrm{C}$. The trapped $\mathrm{SF}_{6}$ is transferred into a small trap cooled in the isopropyl alcohol-dry ice bath by heating the large trap to $96^{\circ} \mathrm{C}$. The small trap is then heated to $96^{\circ} \mathrm{C}$, and opened to inject the $\mathrm{SF}_{6}$ into the gas chromatograph. The measurement is done by an electron capture detector that is controlled by an integrator and a computer.

\section{Sediment}

Sediment samples were analyzed by the USGS Central Region Mineral Resources Laboratory contract laboratory Société Générale de Surveillance (SGS) for major and trace elements following digestion using hydrochloric, nitric, perchloric, and hydrofluoric acids at low temperature. Digested samples were analyzed by ICP-AES and ICP-MS. Calibration on the ICP-AES was performed by standardizing with digested rock reference materials and a series of multi-element solution standards. The ICP-MS was calibrated with aqueous standards, and internal standards were used to compensate for matrix affects and internal drifts. Data were deemed acceptable if recovery for all 42 elements was \pm 15 percent at five times the lower limit of determination (U.S. Geological Survey,
2013). Total carbon and carbonate carbon were measured for every sediment sample, and the difference between total carbon and carbonate carbon was used to calculate organic carbon. The SGS analyzed total carbon using an automated carbon analyzer, where a weighted sample is combusted in an oxic atmosphere at $1,370{ }^{\circ} \mathrm{C}$ to oxidize carbon to carbon dioxide. Moisture and dust are removed and the carbon dioxide is measured by a solid-state infrared detector. Carbonate carbon is determined as carbon dioxide by coulometric titration. The sample is treated with hot 2-normal perchloric acid and the evolved carbon dioxide is passed into a cell containing a solution of monoethanolamine. The carbon dioxide, quantitatively absorbed by the monoethanolamine, is coulometrically titrated using platinum and silver/potassium-iodide electrodes (U.S. Geological Survey, 2013). The lab determined mercury following digestion using nitric and hydrochloric acids using a FIMS-100 (flow injection mercury system) cold-vapor atomic absorption mercury analyzer (U.S. Geological Survey, 2013).

A split of the sediment samples was analyzed by a partial digestion method by the USGS Central Region Mineral Resources Laboratory using the U.S. Environmental Protection Agency (EPA) 3050 method. The partial digestion samples were analyzed by ICP-MS and ICP-AES.

A separate split of 15 of the sediment samples (4 tailings, 4 waste rock, 2 stream sediment, and 5 background) was used to perform a synthetic precipitation leaching procedure (SPLP) by SGS (EPA SPLP method 1312; U.S. Environmental Protection Agency, 1994). The EPA 1312 method uses a 20:1 liquid to solid ratio. The resulting leachate liquid was analyzed by the same methods as the sediment digestion at SGS using ICPAES and ICP-MS. Seven leachate samples were filtered with a $0.45-\mu \mathrm{m}$ filter and acidified to $\mathrm{pH}<2$ with ultrapure nitric acid. The USGS National Research Program Laboratory in Menlo Park, Calif., then measured strontium isotope ratios $\left({ }^{87} \mathrm{Sr} /{ }^{86} \mathrm{Sr}\right)$, using methods described in Bullen and others (1996).

\section{Quality Assurance Procedures}

\section{Water}

One field blank was collected for the groundwater sample set from the site where a Grundfos RediFlo2 portable pump was used to collect the groundwater sample. Certified inorganic blank water was pumped through the pump and sample tubing at the well site prior to sample collection to obtain the field blank. One sequential replicate sample was collected from a different site than the blank sample.

\section{Sediment}

Four field replicate samples were analyzed for total and partial digestions. Three laboratory replicate samples were analyzed for the total digestion and one additional lab replicate for total carbon.

Sediment reference materials are homogenized materials that have been analyzed at multiple laboratories to obtain 
a common value and distribution statistics. The analysis of reference materials along with environmental samples provides an understanding of how accurate laboratory results are. Four reference materials were obtained through the USGS Geochemical Reference Materials program: andesite, AGV-2 (Wilson, 1998a); granodiorite, GSP-2 (Wilson, 1998b); Cody Shale, SCo-1 (Smith, 1995); and Green River Shale, SGR-1b (Wilson, 2001). Blind reference material samples were submitted along with the sediment samples from this study for both total and partial digestion methods. An additional reference material (granodiorite, GSP-2) was submitted by the USGS Central Region Mineral Resources Laboratory to the contract laboratory for quality control analysis.

Three reference materials specific to the EPA 3050 leachate method-2709 (San Joaquin soil), 2710 (Montana soil), and 2711 (Montana soil) — were analyzed by the USGS Central Region Mineral Resources Laboratory during the analysis of the partial digestion samples.

\section{Sediment Leachate}

One replicate was analyzed for sediment leachate samples. The replicate was a separate split from the original sediment sample bag that was leached as a separate sample from the normal sample split and represents variability within a sample as well as lab variability. A separate sample replicate was analyzed for strontium isotopes.

\section{Data Analysis}

The data were analyzed using statistical methods to understand similarities and differences of samples within and between groups. The majority of trace elements had one or more values below a laboratory reporting level, with several elements having multiple reporting levels. The statistical methods of Helsel (2012) for data with values below the laboratory reporting level were used to analyze the majority of analytes presented in this study. Several measured trace elements (Al, As, Ba, Mo, Se, Sr, V, and U) did not result in values below the laboratory reporting level for the dataset reported here.

For censored data (in this case, data below the reporting level), boxplots for elements were made using the "cenboxplot" function from the NADA package (Lee, 2015) in R statistical computing environment (R Core Team, 2015). Outlier data points on boxplots were defined for this study as greater than 1.5 times the interquartile range. We analyzed the chemical analysis data from samples for each constituent to determine the Kaplan-Meier model of the data using "cenfit" from the NADA package in R (Lee, 2015). A p-value threshold of 0.05 (95 percent confidence level) was used to indicate statistical significance for all mentioned statistical tests.

We grouped samples by type of sediment, sediment leachate, and groundwater, then compared sample groups using "cendiff” from the NADA package in R (Lee, 2015). The "cendiff" function uses the Peto-Prentice test (Helsel and Lee, 2006) to determine if there were significant differences between the groups for elements with censored data.

Non-metric multidimensional scaling (NMDS) was used to reduce the complex data structure (many samples and many elements) to represent the pairwise dissimilarity between objects in a low-dimensional space (Buttigieg and Ramette, 2014). We computed Uscores of the data using the "uscore" function for R from Helsel (2016) with default values to calculate the ranks of the scores (Helsel, 2012, 2016). NMDS was performed on the Uscores using "metaMDS" from the vegan package in R (Oksanen and others, 2016) using Euclidean distance, zerodist $=$ add, and autotransform $=$ false (Helsel, 2012). NMDS stress values $\leq 0.1$ are considered fair, values $\leq 0.05$ indicate good fit, and values $\geq 0.2$ are deemed suspect (Buttigieg and Ramette, 2014). For sediment samples, results from all elements were used, and for leachate versus groundwater, a subset of elements ( $\mathrm{Al}, \mathrm{Ag}, \mathrm{As}, \mathrm{Ba}, \mathrm{Cd}, \mathrm{Cr}, \mathrm{Cu}$, $\mathrm{Mn}, \mathrm{Mo}, \mathrm{Ni}, \mathrm{Pb}, \mathrm{Sb}$, Se, Sr, U, V, and Zn) were used as they were available within both datasets.

A cluster analysis was used to identify similar groups of samples by evaluating minimum differences within groups and maximum differences among groups using the "hclust" function for the elements used in the NMDS analysis. The Calinski criterion was applied with the "cascadeKM" function of the vegan package in $\mathrm{R}$ (Oksanen and others, 2016) to determine the number of clusters that maximizes the difference between clusters while minimizing the differences within clusters. The "ANOSIM" function was used to statistically evaluate whether or not groups of samples have significantly different concentration patterns (Helsel, 2012).

Water sample concentrations were compared to the EPA drinking water standards presented in table 2 (U.S. Environmental Protection Agency, 2000, 2017a).

Sediment sample concentrations were compared to the EPA regional and Arizona Department of Environmental Quality (AZDEQ) soil screening levels, presented in table 3 (U.S. Environmental Protection Agency, 2017b; Arizona Department of Environmental Quality, 2009). A comprehensive risk assessment would be needed to understand the screening levels appropriate for the exposure pathways present at the site. 
Table 2. U.S. Environmental Protection Agency water-quality standards for drinking water (U.S. Environmental Protection Agency, 2000, 2017a).

[Values presented in units used in this report. NA, not available; MCL, maximum contaminant level; SMCL, secondary maximum contaminant level; TDS, total dissolved solids; $\mu \mathrm{g} / \mathrm{L}$, microgram per liter; mg/L, milligram per liter]

\begin{tabular}{|c|c|c|c|}
\hline \multirow[t]{2}{*}{ Constituent } & \multirow[t]{2}{*}{ Units } & \multirow{2}{*}{$\begin{array}{c}\text { Primary } \\
\text { drinking-water } \\
\text { standard }\end{array}$} & \multirow{2}{*}{$\begin{array}{c}\begin{array}{c}\text { Secondary } \\
\text { drinking-water } \\
\text { standard }\end{array} \\
\text { SMCL }\end{array}$} \\
\hline & & & \\
\hline $\mathrm{Al}$ & $\mu \mathrm{g} / \mathrm{L}$ & NA & $50-200$ \\
\hline $\mathrm{Sb}$ & $\mu \mathrm{g} / \mathrm{L}$ & 6 & NA \\
\hline As & $\mu \mathrm{g} / \mathrm{L}$ & 10 & NA \\
\hline $\mathrm{Ba}$ & $\mu \mathrm{g} / \mathrm{L}$ & 2,000 & NA \\
\hline $\mathrm{Be}$ & $\mu \mathrm{g} / \mathrm{L}$ & 4 & NA \\
\hline $\mathrm{Cd}$ & $\mu g / L$ & 5 & NA \\
\hline $\mathrm{Cl}^{-}$ & $\mathrm{mg} / \mathrm{L}$ & NA & 250 \\
\hline $\mathrm{Cr}$ & $\mu g / L$ & 100 & NA \\
\hline $\mathrm{Cu}$ & $\mu \mathrm{g} / \mathrm{L}$ & 1,300 & 1,000 \\
\hline $\mathrm{F}^{-}$ & $\mathrm{mg} / \mathrm{L}$ & 4 & 2 \\
\hline $\mathrm{Fe}$ & $\mu \mathrm{g} / \mathrm{L}$ & NA & 300 \\
\hline $\mathrm{Pb}$ & $\mu \mathrm{g} / \mathrm{L}$ & 15 & NA \\
\hline $\mathrm{Mn}$ & $\mu \mathrm{g} / \mathrm{L}$ & NA & 50 \\
\hline $\mathrm{NO}_{3}^{-}$, as $\mathrm{N}$ & $\mathrm{mg} / \mathrm{L}$ & 10 & NA \\
\hline $\mathrm{pH}$ & standard scale & NA & $6.5-8.5$ \\
\hline Se & $\mu g / L$ & 50 & NA \\
\hline $\mathrm{Ag}$ & $\mu g / L$ & NA & 100 \\
\hline $\mathrm{SO}_{4}^{2-}$ & $\mathrm{mg} / \mathrm{L}$ & NA & 250 \\
\hline TDS & $\mathrm{mg} / \mathrm{L}$ & NA & 500 \\
\hline $\mathrm{U}$ & $\mu g / L$ & 30 & NA \\
\hline $\mathrm{Zn}$ & $\mu \mathrm{g} / \mathrm{L}$ & NA & 5,000 \\
\hline
\end{tabular}


Table 3. U.S. Environmental Protection Agency (EPA) and Arizona Department of Environmental Quality (AZDEQ) soil screening levels (U.S. Environmental Protection Agency, 2017b; Arizona Department of Environmental Quality, 2009).

[Values in milligrams per kilogram (mg/kg); NA, not available]

\begin{tabular}{|c|c|c|c|}
\hline \multirow[b]{2}{*}{ Element } & \multicolumn{2}{|c|}{ EPA (composite worker) } & \multirow{2}{*}{$\begin{array}{c}\text { AZDEO } \\
\text { (non-residential) }\end{array}$} \\
\hline & $\begin{array}{c}\text { Carcinogenic } \\
\text { target risk }\end{array}$ & $\begin{array}{l}\text { Non-cancer } \\
\text { hazard index }\end{array}$ & \\
\hline $\mathrm{Al}$ & NA & $1,100,000$ & 920,000 \\
\hline $\mathrm{Sb}$ & NA & 470 & 410 \\
\hline As & 3 & 480 & 10 \\
\hline $\mathrm{Ba}$ & NA & 220,000 & 170,000 \\
\hline $\mathrm{Be}$ & 6,900 & 2,300 & 1,900 \\
\hline $\mathrm{Cd}$ & 9,300 & 980 & 510 \\
\hline Co & 1,900 & 350 & 13,000 \\
\hline $\mathrm{Cu}$ & NA & 47,000 & 41,000 \\
\hline $\mathrm{Pb}$ & NA & 800 & 800 \\
\hline Mn & NA & 26,000 & 32,000 \\
\hline $\mathrm{Hg}$ & NA & 46 & 310 \\
\hline Mo & NA & 5,800 & 5,100 \\
\hline $\mathrm{Ni}$ & NA & NA & 20,000 \\
\hline Ag & NA & 5,800 & 5,100 \\
\hline $\mathrm{U}$ & NA & $230^{\mathrm{a}}$ & 200 \\
\hline $\mathrm{V}$ & NA & 5,800 & 1,000 \\
\hline $\mathrm{Zn}$ & NA & 350,000 & 310,000 \\
\hline
\end{tabular}

${ }^{a}$ Uranium soluble salts.

\section{Results}

\section{Quality Assessment}

\section{Water}

Charge balance difference for all samples was less than 5 percent, with a maximum percentage difference of 3.2 percent. All samples were checked and those with values greater than the EPA drinking water standards (U.S. Environmental Protection Agency, 2000, 2017a; table 2) were rerun and verified. Equipment for field parameter measurement and alkalinity titrations was tested during the USGS annual National Field Quality Assurance project, and measurements produced results within the acceptable range.

Nine constituents from the one blank sample collected had values above the laboratory reporting level $(\mathrm{Ca}, \mathrm{Cl}$, ammonia [ $\mathrm{NH}_{4}$ ], $\mathrm{Cr}, \mathrm{Cu}, \mathrm{Mn}, \mathrm{Mo}, \mathrm{Ni}$, and Zn; table 4). Calcium and chloride concentrations in the blank sample were more than 100 times less than those in the environmental samples (table 4). Ammonia, $\mathrm{Cr}, \mathrm{Cu}, \mathrm{Mn}, \mathrm{Mo}, \mathrm{Ni}$, and $\mathrm{Zn}$ concentrations in the blank samples were less than 10 times some, or all, of each respective constituent concentration in the environmental samples. The blank was collected from the portable pump, which was used at one sample site and likely represents greater potential for contamination compared with other dedicated pump sites. More blank measurements would be needed to statistically understand the potential bias from contamination in the sampling equipment and field conditions.

One groundwater replicate was sampled for this study and the relative percentage differences between the environmental sample and the replicate were less than 10 percent for all constituents, except for lead, perchlorate, and zinc (table 5). More replicate samples would be needed to statistically quantify the variability for each element. 
Table 4. Results of field blank analyses.

[Bold values indicate detection above the laboratory reporting level. mg/L, milligrams per liter; $\mu \mathrm{g} / \mathrm{L}$, micrograms per liter; NA, not available]

\begin{tabular}{|c|c|c|c|c|c|}
\hline Constituent & Units & Detection level & Reporting level & Blank value & Environmental sample range \\
\hline $\mathrm{Ca}$ & $\mathrm{mg} / \mathrm{L}$ & 0.022 & 0.044 & 0.153 & $18.5-364$ \\
\hline $\mathrm{Mg}$ & $\mathrm{mg} / \mathrm{L}$ & 0.011 & 0.022 & $<0.011$ & $0.863-63.7$ \\
\hline $\mathrm{Na}$ & $\mathrm{mg} / \mathrm{L}$ & 0.06 & 0.12 & $<0.06$ & $47-167$ \\
\hline $\mathrm{K}$ & $\mathrm{mg} / \mathrm{L}$ & 0.03 & 0.06 & 0.04 & $1.39-6.61$ \\
\hline $\mathrm{Cl}^{-}$ & $\mathrm{mg} / \mathrm{L}$ & 0.02 & 0.04 & 0.049 & $27.7-742$ \\
\hline $\mathrm{SO}_{4}^{2-}$ & $\mathrm{mg} / \mathrm{L}$ & 0.02 & 0.04 & 0.025 & $20-134$ \\
\hline $\mathrm{F}^{-}$ & $\mathrm{mg} / \mathrm{L}$ & 0.01 & 0.02 & $<0.01$ & $0.15-0.75$ \\
\hline $\mathrm{NH}_{3}$, as $\mathrm{N}$ & $\mathrm{mg} / \mathrm{L}$ & 0.01 & 0.02 & 0.022 & $<0.01-1.83$ \\
\hline $\mathrm{NO}_{2}$, as $\mathrm{N}$ & $\mathrm{mg} / \mathrm{L}$ & 0.001 & 0.002 & $<0.001$ & $<0.001-0.004$ \\
\hline $\mathrm{NH}_{3}$ plus $\mathrm{NO}_{2}$, as $\mathrm{N}$ & $\mathrm{mg} / \mathrm{L}$ & 0.04 & 0.08 & $<0.04$ & $3.86-8.87$ \\
\hline $\mathrm{PO}_{4}^{3-}$, as $\mathrm{P}$ & $\mathrm{mg} / \mathrm{L}$ & 0.004 & 0.008 & $<0.004$ & $0.009-0.053$ \\
\hline $\mathrm{Al}$ & $\mu \mathrm{g} / \mathrm{L}$ & 3 & 6 & $<3$ & $5.2-9.2$ \\
\hline As & $\mu g / L$ & 0.1 & 0.2 & $<0.1$ & $2.8-10.7$ \\
\hline $\mathrm{Sb}$ & $\mu \mathrm{g} / \mathrm{L}$ & 0.027 & 0.054 & $<0.027$ & $<0.054-1.65$ \\
\hline $\mathrm{Ba}$ & $\mu \mathrm{g} / \mathrm{L}$ & 0.6 & 1.2 & 0.69 & $13.4-228$ \\
\hline $\mathrm{Be}$ & $\mu \mathrm{g} / \mathrm{L}$ & 0.19 & 0.38 & $<0.19$ & $<0.19-<0.76$ \\
\hline $\mathrm{Cd}$ & $\mu \mathrm{g} / \mathrm{L}$ & 0.6 & 1.2 & $<0.6$ & $<0.6-<2.4$ \\
\hline $\mathrm{Cr}$ & $\mu \mathrm{g} / \mathrm{L}$ & 0.3 & 0.6 & 0.99 & $<0.30-6.5$ \\
\hline $\mathrm{Cu}$ & $\mu g / L$ & 0.8 & 1.6 & 3.54 & $<0.8-2$ \\
\hline $\mathrm{Fe}$ & $\mu \mathrm{g} / \mathrm{L}$ & 4 & 8 & 6.55 & $<4-2,020$ \\
\hline $\mathrm{Pb}$ & $\mu \mathrm{g} / \mathrm{L}$ & 0.04 & 0.08 & 0.048 & $<0.08-3.68$ \\
\hline $\mathrm{Mn}$ & $\mu \mathrm{g} / \mathrm{L}$ & 0.2 & 0.4 & 14 & $<0.2-2,200$ \\
\hline Mo & $\mu \mathrm{g} / \mathrm{L}$ & 0.05 & 0.1 & 4.58 & $2.97-14.6$ \\
\hline $\mathrm{Ni}$ & $\mu \mathrm{g} / \mathrm{L}$ & 0.2 & 0.4 & 214 & $<0.2-2.4$ \\
\hline Se & $\mu g / L$ & 0.05 & 0.1 & $<0.05$ & $0.64-2.5$ \\
\hline Ag & $\mu \mathrm{g} / \mathrm{L}$ & 0.02 & 0.04 & $<0.02$ & $<0.02-<1$ \\
\hline $\mathrm{U}$ & $\mu g / L$ & 0.014 & 0.028 & $<0.014$ & $1.32-11.3$ \\
\hline $\mathrm{V}$ & $\mu \mathrm{g} / \mathrm{L}$ & 0.6 & 1.2 & $<0.6$ & $6.6-20.4$ \\
\hline $\mathrm{Zn}$ & $\mu g / L$ & 1.9 & 3.8 & 4.62 & $<1.9-108$ \\
\hline $\mathrm{ClO}_{4}^{-}$ & $\mu \mathrm{g} / \mathrm{L}$ & NA & 0.1 & $<0.1$ & $0.67-1.48$ \\
\hline
\end{tabular}


Table 5. Results of groundwater replicate analyses.

[Bold value indicates the percentage difference is greater than 10 percent. $\mathrm{mg} / \mathrm{L}$, milligram per liter; $\mu \mathrm{g} / \mathrm{L}$, microgram per liter; pCi/L, picocurie per liter; $\mathrm{pM}$, absolute percent modern carbon (normalized); $\mathrm{fg} / \mathrm{kg}$, femtogram per kilogram ( $\left.1 \mathrm{femtogram}=10^{-15} \mathrm{grams}\right) ; \mu \mathrm{S} / \mathrm{cm}$, microsiemens per centimeter; $\mathrm{R}$, radiochemistry non-detect; NA, not applicable]

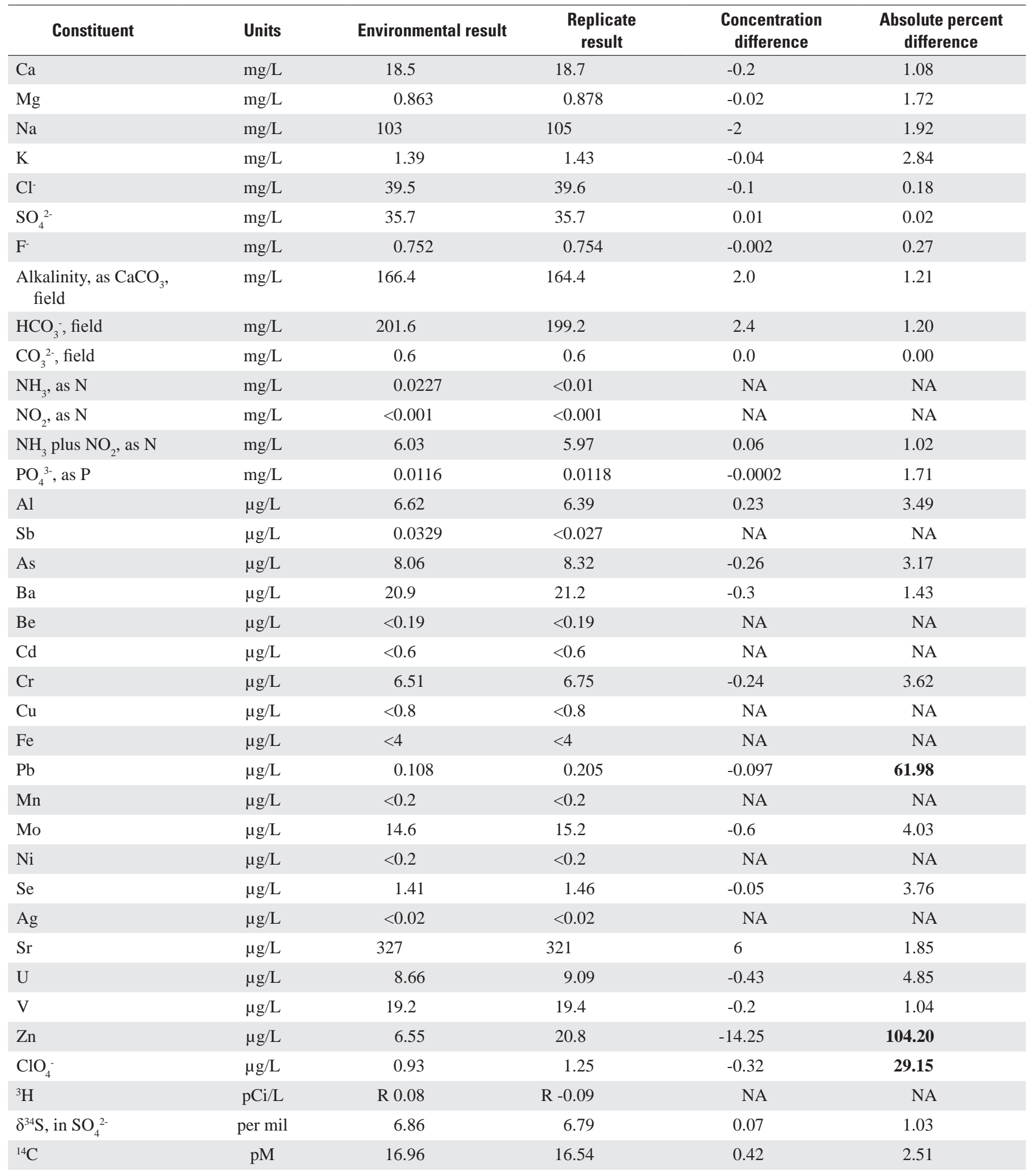


Table 5. Results of groundwater replicate analyses. - Continued

[Bold value indicates the percentage difference is greater than 10 percent. mg/L, milligram per liter; $\mu \mathrm{g} / \mathrm{L}$, microgram per liter; pCi/L, picocurie per liter; $\mathrm{pM}$, absolute percent modern carbon (normalized); fg $/ \mathrm{kg}$, femtogram per kilogram ( 1 femtogram $=10^{-15}$ grams); $\mu \mathrm{S} / \mathrm{cm}$, microsiemens per centimeter; R, radiochemistry non-detect; NA, not applicable]

\begin{tabular}{|c|c|c|c|c|c|}
\hline Constituent & Units & Environmental result & $\begin{array}{l}\text { Replicate } \\
\text { result }\end{array}$ & $\begin{array}{c}\text { Concentration } \\
\text { difference }\end{array}$ & $\begin{array}{c}\text { Absolute percent } \\
\text { difference }\end{array}$ \\
\hline $\mathrm{SF}_{6}$ & fg/kga & 264.50 & 261.40 & 3.10 & 1.18 \\
\hline${ }^{87} \mathrm{Sr} /{ }^{86} \mathrm{Sr}$ & & 0.70968 & 0.70971 & -0.00003 & 0.00 \\
\hline$\delta^{13} \mathrm{C}$ & per mil & -10.08 & -10.07 & -0.01 & 0.10 \\
\hline $\mathrm{pH}, \mathrm{lab}$ & standard scale & 8.2 & 8.1 & 0.1 & 1.23 \\
\hline SpecCond, lab ${ }^{\mathrm{b}}$ & $\mu \mathrm{S} / \mathrm{cm}$ & 559 & 559 & 0 & 0.00 \\
\hline $\mathrm{ANC}^{\mathrm{c}}$, as $\mathrm{CaCO}_{3}$, lab & $\mathrm{mg} / \mathrm{L}$ & 169 & 169 & 0 & 0.00 \\
\hline
\end{tabular}

a TDS, total dissolved solids, at $180^{\circ} \mathrm{C}$.

${ }^{\mathrm{b}}$ SpecCond, specific conductance, at $25^{\circ} \mathrm{C}$.

${ }^{\mathrm{c}} \mathrm{ANC}$, acid-neutralizing capacity.

\section{Sediment}

Four field and three laboratory replicate sediment samples (plus one additional total carbon laboratory replicate) were analyzed with the total digestion method. Relative percentage differences between field environmental samples and replicates were generally less than 20 percent, with the exception of $\mathrm{Bi}$ (29 percent) and $\mathrm{Hg}$ (40 percent) for OYM-31-B, Mo (29 percent) for OYM-22-S, and Sn (49 percent) for OYM-33-B (table 6). For the laboratory replicates, one sample (OYM-05-T) had three elements whose relative percentage difference was greater than 20 percent: Hg (22 percent), Sn (21 percent), and Te (67 percent) (table 7).

For the 3050 partial-digestion method field replicates, relative percentage difference between field environmental samples and replicates were generally less than 20 percent, with the exception of Fe (26 percent) for OYM-33-B, Nd (22 percent) and $\mathrm{Pb}$ (23 percent) for OYM-31-B, Mo (43 percent) for OYM-22-S, and Li (22 percent) for OYM-02-T (table 8).

For standard reference materials analyzed by total digestion, elements Cr in SCo-1 (Smith, 1995), Ti in GSP-2 (Wilson, 1998b), and Fe, Mg, Cr, Mn, Pb, and Sr in AGV-2 (Wilson, 1998a) had laboratory results greater than three standard deviations of the reported value for the associated reference material (table 9). Relative percentage difference between the reported values and the SGS laboratory values were generally less than 20 percent with the exception of $\mathrm{Cr}$ (24 percent) and Y (28 percent) in SCo-1; Ga (29 percent), Nb (62 percent), and Y (22 percent) in SGR-1b; Cr (35 percent) in GSP-2; Be (22 percent), Cr (47 percent), $\mathrm{Pb}$ (69 percent) and $\mathrm{Sb}$ (27 percent) in $\mathrm{AGV}-2$; and $\mathrm{CO}_{2}$ (21 percent), carbonate carbon (22 percent), organic carbon (22 percent), and Mn (22 percent) in GSP-2.

Reference materials analyzed by the EPA 3050 method represent a partial digestion and certified values do not exist with which to compare results. Rather, results can be compared with a range from other laboratory results analyzed using the same method (National Institute of Standards and Technology, 2003; table 10). Most values reported here for reference materials analyzed by the EPA 3050 method are within the range reported by other laboratories. Some constituents had values outside of the reported range, which is commonly representative of results from a smaller number of reporting laboratories (2-9), depending on the element. Titanium and vanadium were the only two elements whose laboratory values were outside of the range for all reference materials (2709, 2710, and 2711) (table 10). 


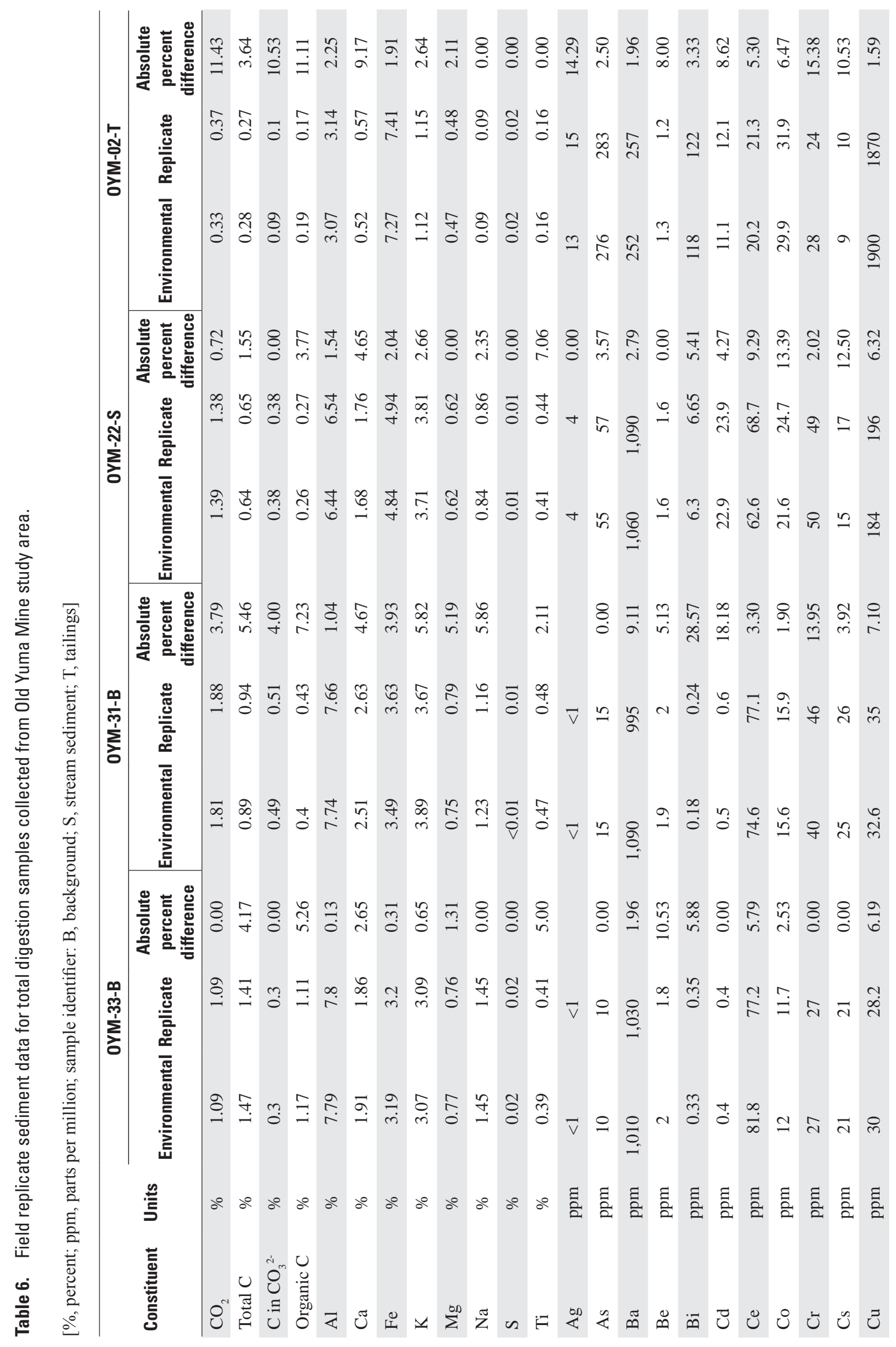




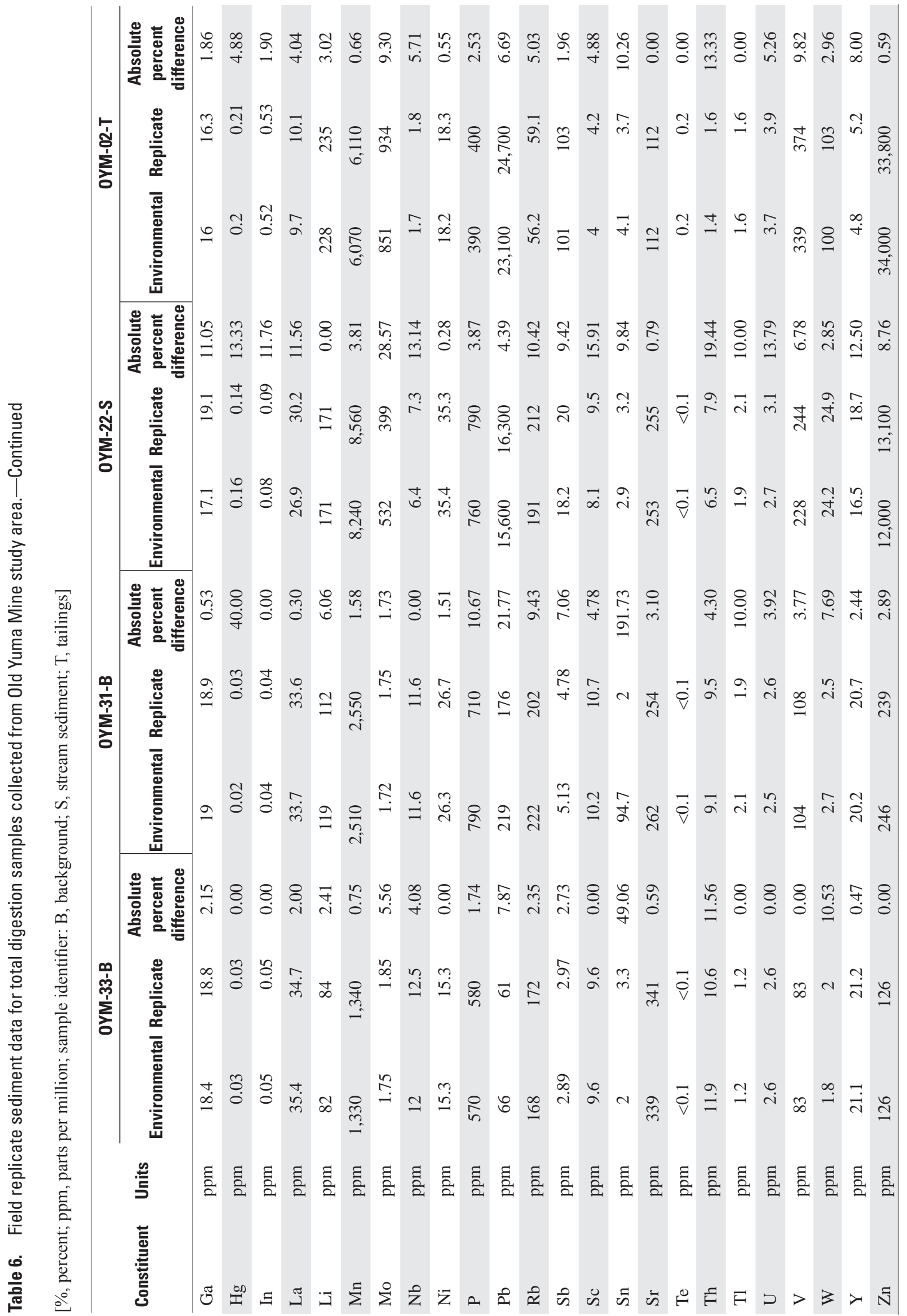




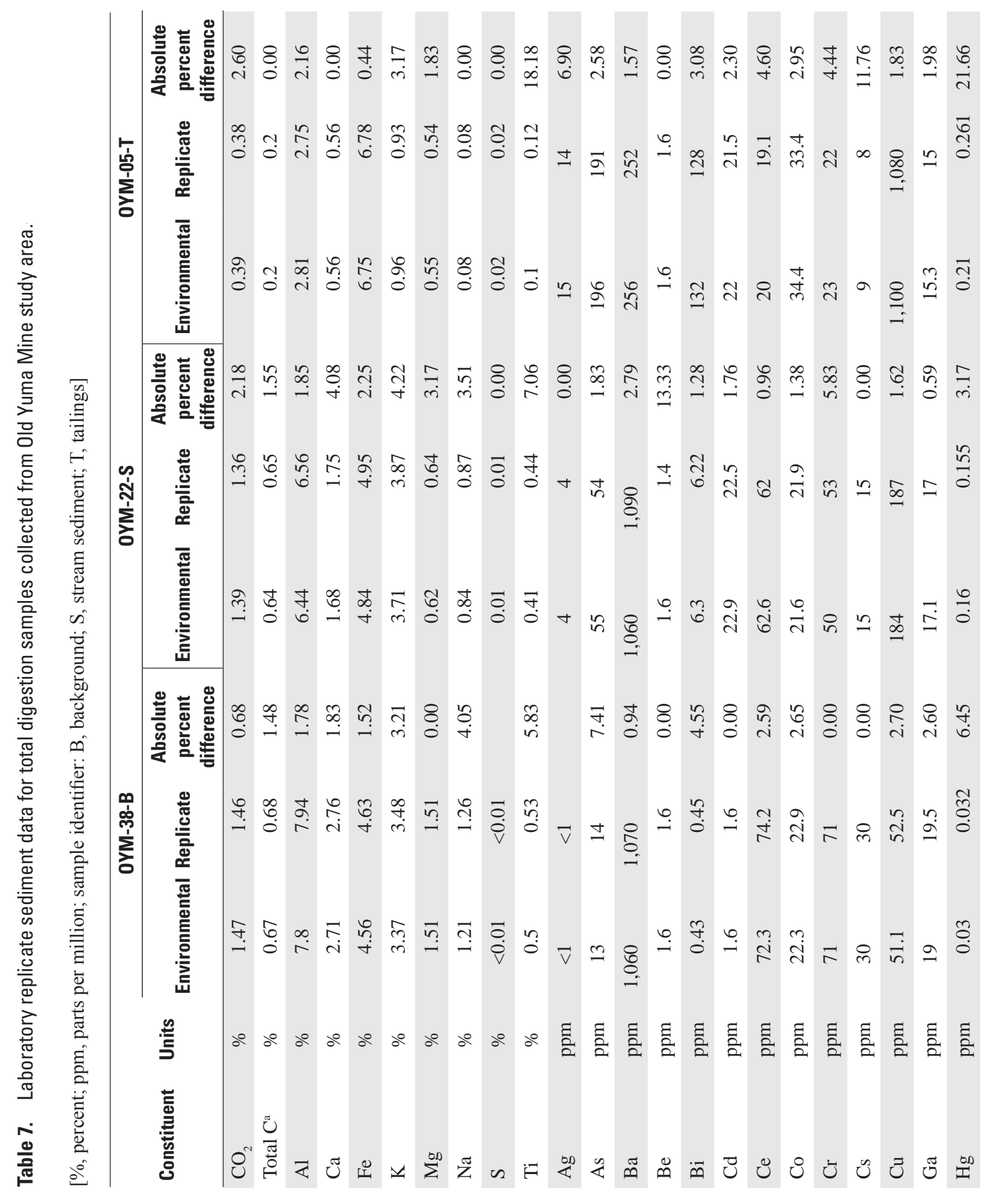




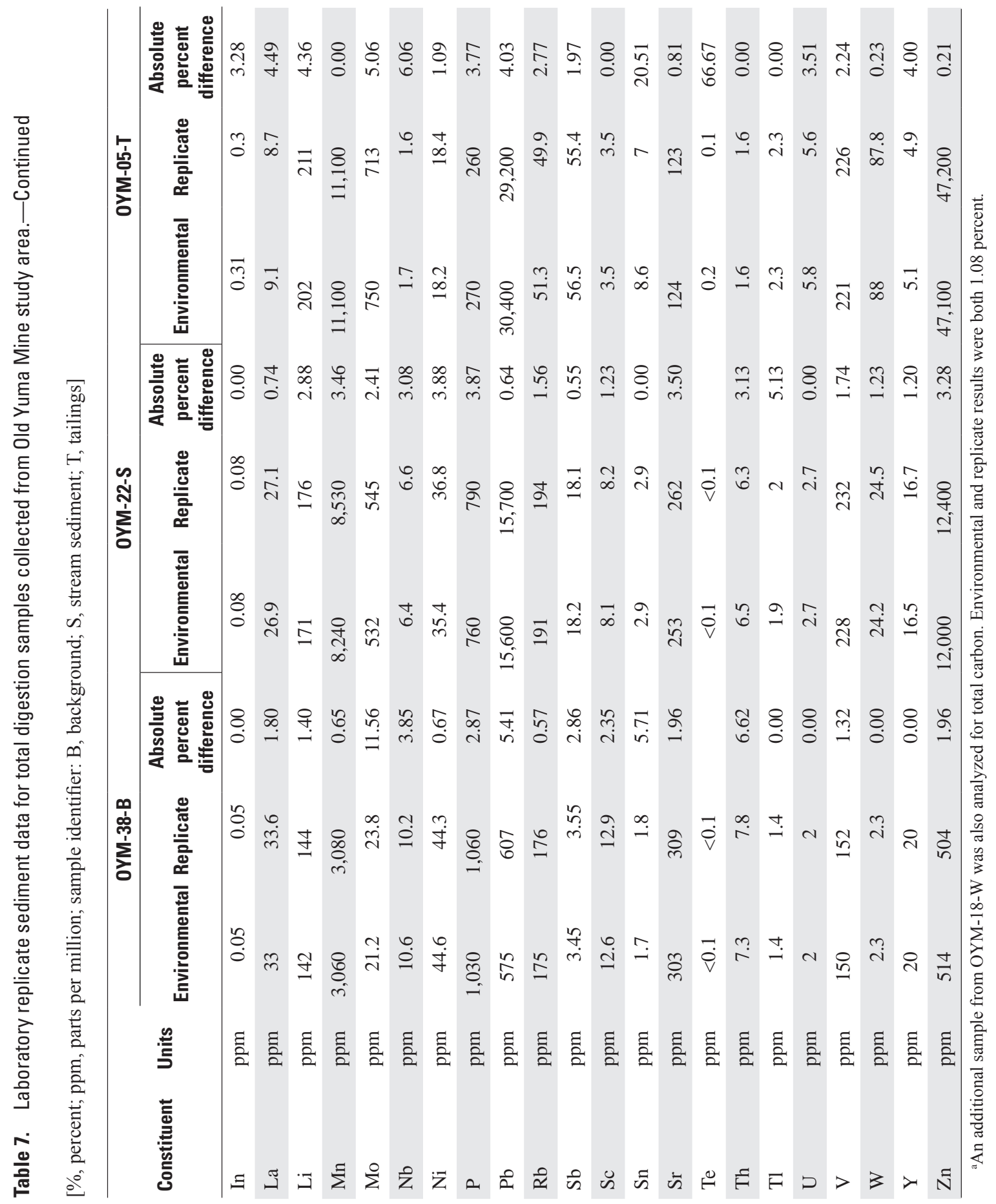




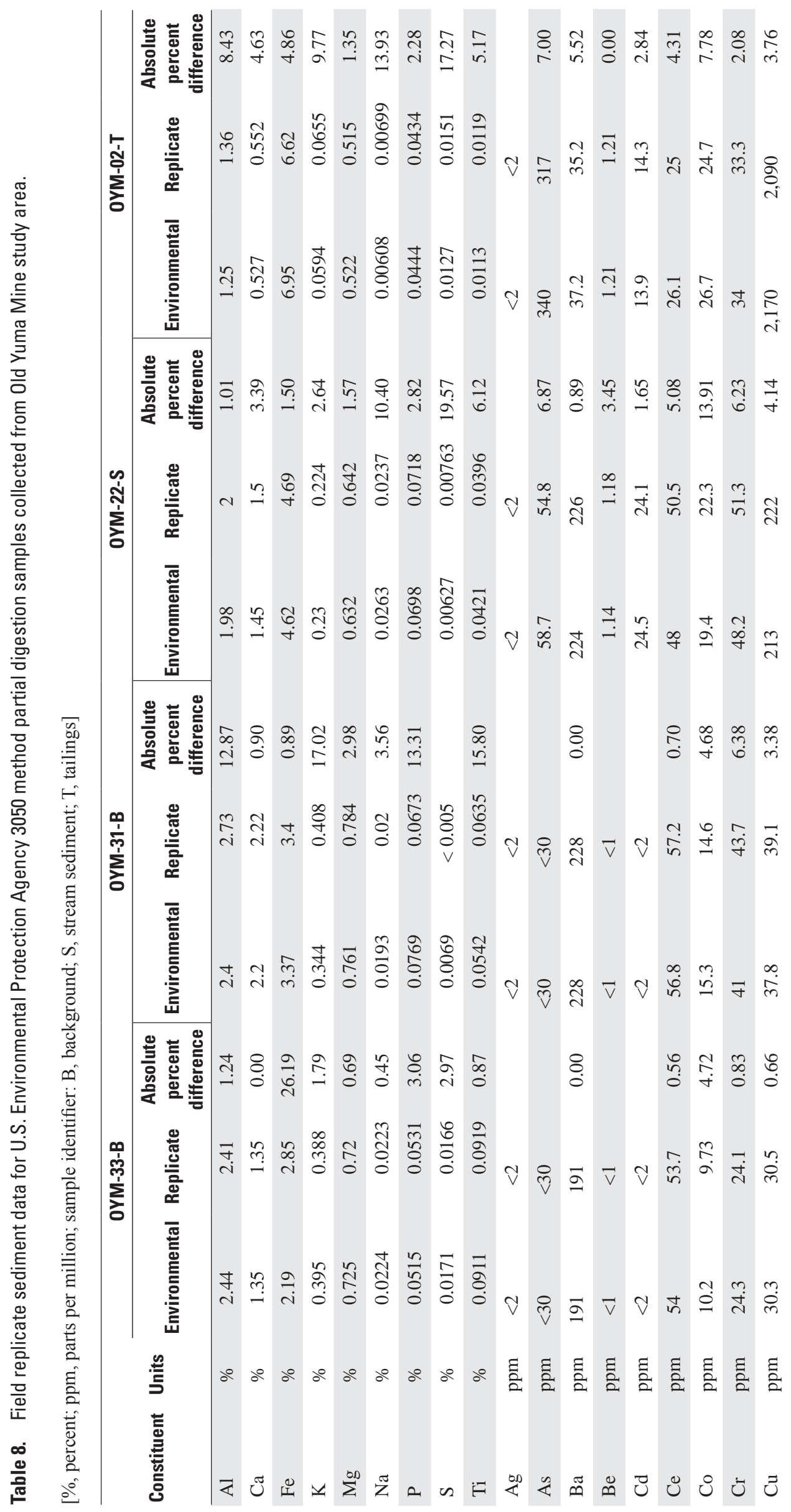




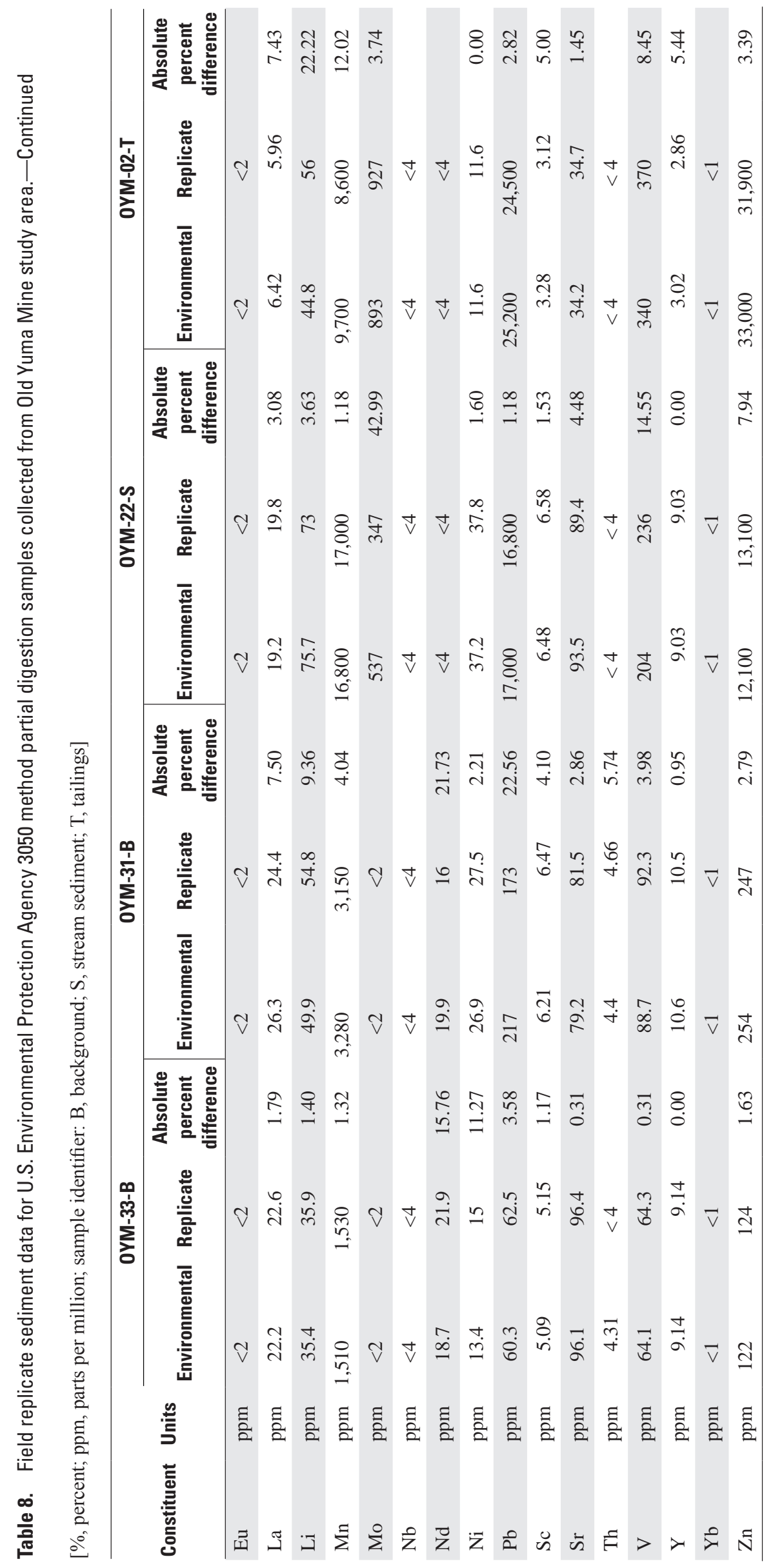


Table 9A. Total digestion results for sediment reference materials Cody Shale (SCo-1), Green River Shale (SGR-1b), and Granodiorite (GSP-2).

[Accepted reference material concentrations from Smith (1995) and Wilson (1998a, b; 2001). \%, percent; ppm, parts per million; SGS, Société Générale de Surveillance; - , not available]

\begin{tabular}{|c|c|c|c|c|c|c|c|c|c|c|c|c|c|}
\hline \multirow[b]{3}{*}{ Constituent } & \multirow[b]{3}{*}{ Unit } & \multicolumn{4}{|c|}{ Cody Shale SCo-1 } & \multicolumn{4}{|c|}{ Green River Shale SGR-1b } & \multicolumn{4}{|c|}{ Granodiorite GSP-2 } \\
\hline & & \multicolumn{2}{|c|}{ Reported } & \multicolumn{2}{|c|}{$\begin{array}{l}\text { USGS Contract } \\
\text { Lab SGS }\end{array}$} & \multicolumn{2}{|c|}{ Reported } & \multicolumn{2}{|c|}{$\begin{array}{c}\text { USGS Contract } \\
\text { Lab SGS }\end{array}$} & \multicolumn{2}{|c|}{ Reported } & \multicolumn{2}{|c|}{$\begin{array}{l}\text { USGS Contract } \\
\text { Lab SGS }\end{array}$} \\
\hline & & Value & $\begin{array}{l}\text { Standard } \\
\text { deviation }\end{array}$ & Lab value & $\begin{array}{c}\text { Absolute } \\
\text { percent } \\
\text { difference }\end{array}$ & Value & $\begin{array}{l}\text { Standard } \\
\text { deviation }\end{array}$ & $\begin{array}{c}\text { Lab } \\
\text { value }\end{array}$ & $\begin{array}{c}\text { Absolute } \\
\text { percent } \\
\text { difference }\end{array}$ & Value & $\begin{array}{l}\text { Standard } \\
\text { deviation }\end{array}$ & $\begin{array}{l}\text { Lab } \\
\text { value }\end{array}$ & $\begin{array}{l}\text { Absolute } \\
\text { percent } \\
\text { difference }\end{array}$ \\
\hline $\mathrm{CO}_{2}$ & $\%$ & - & - & - & - & - & - & - & - & - & - & - & - \\
\hline Total C & $\%$ & - & - & 1 & - & - & - & 27.9 & - & - & - & 0.09 & - \\
\hline $\mathrm{C}$ in $\mathrm{CO}_{3}{ }^{2-}$ & $\%$ & - & - & 0.69 & - & - & - & 2.97 & - & - & - & 0.04 & - \\
\hline Organic C & $\%$ & - & - & 0.31 & - & - & - & 24.93 & - & - & - & 0.05 & - \\
\hline $\mathrm{Al}$ & $\%$ & - & - & 6.98 & - & - & - & 3.53 & - & 7.88 & 0.11 & 7.82 & 1 \\
\hline $\mathrm{Ca}$ & $\%$ & - & - & 1.8 & - & - & - & 5.74 & - & 1.5 & 0.04 & 1.51 & 1 \\
\hline $\mathrm{Fe}$ & $\%$ & - & - & 3.26 & - & - & - & 1.88 & - & 3.43 & 0.11 & 3.2 & 7 \\
\hline $\mathrm{K}$ & $\%$ & - & - & 2.28 & - & - & - & 1.38 & - & 4.48 & 0.12 & 4.33 & 3 \\
\hline $\mathrm{Mg}$ & $\%$ & - & - & 1.45 & - & - & - & 2.46 & - & 0.58 & 0.02 & 0.53 & 9 \\
\hline $\mathrm{Na}$ & $\%$ & - & - & 0.61 & - & - & - & 2.15 & - & 2.06 & 0.07 & 1.91 & 7 \\
\hline S & $\%$ & 0.063 & 0.009 & 0.07 & 11 & 1.53 & 0.11 & 1.53 & 0 & - & - & 0.05 & - \\
\hline $\mathrm{Ti}$ & $\%$ & - & - & 0.29 & - & - & - & 0.13 & - & 0.4 & 0.01 & 0.34 & 15 \\
\hline Ag & $\mathrm{ppm}$ & - & - & $<1$ & - & - & - & $<1$ & - & - & - & $<1$ & - \\
\hline As & ppm & 12 & 1 & 12 & 0 & 67 & 5 & 64 & 4 & - & - & 2 & - \\
\hline $\mathrm{Ba}$ & ppm & 570 & 30 & 541 & 5 & 290 & 40 & 271 & 7 & 1,340 & 44 & 1,320 & 1 \\
\hline $\mathrm{Be}$ & ppm & 1.8 & 0.2 & 2.1 & 17 & - & - & 1 & - & 1.5 & 0.2 & 1.4 & 7 \\
\hline $\mathrm{Bi}$ & ppm & 0.37 & - & 0.37 & 0 & - & - & 0.79 & - & - & - & 0.06 & - \\
\hline $\mathrm{Cd}$ & ppm & - & - & 0.1 & - & 0.9 & - & 1 & 11 & - & - & $<0.1$ & - \\
\hline $\mathrm{Ce}$ & $\mathrm{ppm}$ & 62 & 6 & 57.7 & 7 & 36 & 4 & 36.7 & 2 & 410 & 30 & 439 & 7 \\
\hline Co & ppm & 11 & 0.8 & 10.8 & 2 & 12 & 1.5 & 11.5 & 4 & 7.3 & 0.8 & 7.4 & 1 \\
\hline $\mathrm{Cr}$ & ppm & 68 & 5 & 52 & 24 & 30 & 3 & 24 & 20 & 20 & 6 & 13 & 35 \\
\hline Cs & ppm & 7.8 & 0.7 & 8 & 3 & 5.2 & 0.3 & 5 & 4 & 1.2 & 0.1 & $<5$ & - \\
\hline $\mathrm{Cu}$ & ppm & 29 & 2 & 24.9 & 14 & 66 & 9 & 65.8 & 0 & 43 & 4 & 42.8 & 0 \\
\hline $\mathrm{Ga}$ & $\mathrm{ppm}$ & 15 & - & 17 & 13 & 12 & - & 8.55 & 29 & 22 & 2 & 23.1 & 5 \\
\hline $\mathrm{Hg}$ & ppm & - & - & 0.08 & - & 0.3 & - & 0.25 & 17 & - & - & 0.02 & - \\
\hline In & ppm & - & - & 0.05 & - & - & - & 0.03 & - & - & - & 0.04 & - \\
\hline $\mathrm{La}$ & ppm & 30 & 1 & 28.1 & 6 & 20 & 1.8 & 18.7 & 7 & 180 & 12 & 183 & 2 \\
\hline $\mathrm{Li}$ & ppm & 45 & 3 & 43 & 4 & 147 & 26 & 136 & 7 & 36 & 1 & 35 & 3 \\
\hline $\mathrm{Mn}$ & ppm & 410 & 30 & 351 & 14 & 267 & 34 & 222 & 17 & 320 & 20 & 293 & 8 \\
\hline Mo & ppm & 1.4 & 0.2 & 1.22 & 13 & 35 & 0.9 & 32.2 & 8 & 2.1 & 0.6 & 2.38 & 13 \\
\hline $\mathrm{Nb}$ & ppm & 11 & - & 10.3 & 6 & 5.2 & - & 8.4 & 62 & 27 & 2 & 23.4 & 13 \\
\hline $\mathrm{Ni}$ & ppm & 27 & 4 & 22.9 & 15 & 29 & - & 25.9 & 11 & 17 & 2 & 14.8 & 13 \\
\hline $\mathrm{P}$ & ppm & - & - & 830 & - & - & - & 1,170 & - & 1,300 & 100 & 1,240 & 5 \\
\hline $\mathrm{Pb}$ & ppm & 31 & 3 & 31 & 0 & 38 & 4 & 43 & 13 & 42 & 3 & 40 & 5 \\
\hline $\mathrm{Rb}$ & $\mathrm{ppm}$ & 110 & 4 & 112 & 2 & - & - & 80.3 & - & 245 & 7 & 244 & 0 \\
\hline $\mathrm{Sb}$ & ppm & 2.5 & 0.1 & 2.6 & 4 & 3.4 & 0.5 & 3.81 & 12 & - & - & 0.42 & - \\
\hline Sc & $\mathrm{ppm}$ & 11 & 1 & 11.7 & 6 & 4.6 & 0.7 & 5 & 9 & 6.3 & 0.7 & 6.1 & 3 \\
\hline
\end{tabular}


Table 9A. Total digestion results for sediment reference materials Cody Shale (SCo-1), Green River Shale (SGR-1b), and Granodiorite (GSP-2).-Continued

[Accepted reference material concentrations from Smith (1995) and Wilson (1998a, b; 2001). \%, percent; ppm, parts per million; SGS, Société Générale de Surveillance; - , not available]

\begin{tabular}{|c|c|c|c|c|c|c|c|c|c|c|c|c|c|}
\hline \multirow[b]{3}{*}{ Constituent } & \multirow[b]{3}{*}{ Unit } & \multicolumn{4}{|c|}{ Cody Shale SCo-1 } & \multicolumn{4}{|c|}{ Green River Shale SGR-1b } & \multicolumn{4}{|c|}{ Granodiorite GSP-2 } \\
\hline & & \multicolumn{2}{|c|}{ Reported } & \multicolumn{2}{|c|}{$\begin{array}{l}\text { USGS Contract } \\
\text { Lab SGS }\end{array}$} & \multicolumn{2}{|c|}{ Reported } & \multicolumn{2}{|c|}{$\begin{array}{l}\text { USGS Contract } \\
\text { Lab SGS }\end{array}$} & \multicolumn{2}{|c|}{ Reported } & \multicolumn{2}{|c|}{$\begin{array}{l}\text { USGS Contract } \\
\text { Lab SGS }\end{array}$} \\
\hline & & Value & $\begin{array}{l}\text { Standard } \\
\text { deviation }\end{array}$ & Lab value & $\begin{array}{c}\text { Absolute } \\
\text { percent } \\
\text { difference }\end{array}$ & Value & $\begin{array}{l}\text { Standard } \\
\text { deviation }\end{array}$ & $\begin{array}{l}\text { Lab } \\
\text { value }\end{array}$ & $\begin{array}{c}\text { Absolute } \\
\text { percent } \\
\text { difference }\end{array}$ & Value & $\begin{array}{l}\text { Standard } \\
\text { deviation }\end{array}$ & $\begin{array}{l}\text { Lab } \\
\text { value }\end{array}$ & $\begin{array}{c}\text { Absolute } \\
\text { percent } \\
\text { difference }\end{array}$ \\
\hline Sn & ppm & 3.7 & - & 3.4 & 8 & 1.9 & - & 1.7 & 11 & - & - & 6.6 & - \\
\hline $\mathrm{Sr}$ & ppm & 170 & 16 & 150 & 12 & 420 & 30 & 360 & 14 & 240 & 10 & 224 & 7 \\
\hline $\mathrm{Te}$ & ppm & - & - & $<0.1$ & - & - & - & 0.2 & - & - & - & $<0.1$ & - \\
\hline Th & ppm & 9.7 & 0.5 & 9.9 & 2 & 4.8 & 0.21 & 4.9 & 2 & 105 & 8 & 113 & 8 \\
\hline $\mathrm{Tl}$ & ppm & - & - & 0.6 & - & - & - & 0.5 & - & - & - & 1.3 & - \\
\hline $\mathrm{U}$ & ppm & - & - & 2.9 & - & 5.4 & 0.4 & 5.4 & 0 & 2.4 & 0.19 & 2.3 & 4 \\
\hline $\mathrm{V}$ & ppm & 130 & 13 & 121 & 7 & 130 & 6 & 112 & 14 & 52 & 4 & 49 & 6 \\
\hline W & ppm & 1.4 & - & 1.3 & 7 & 2.6 & 0.06 & 2.4 & 8 & - & - & 0.6 & - \\
\hline $\mathrm{Y}$ & ppm & 26 & 4 & 18.6 & 28 & 13 & - & 10.1 & 22 & 28 & 2 & 26.5 & 5 \\
\hline $\mathrm{Zn}$ & ppm & 100 & 8 & 100 & 0 & 74 & 9 & 70 & 5 & 120 & 10 & 117 & 3 \\
\hline
\end{tabular}

Table 9B. Total digestion results for sediment reference materials Andesite (AGV-2) and Granodiorite (GSP).

[Accepted reference material concentrations from Smith (1995) and Wilson (1998a, b; 2001). \%, percent; ppm, parts per million; SGS, Société Générale de Surveillance; ,- not available]

\begin{tabular}{|c|c|c|c|c|c|c|c|c|c|}
\hline \multirow[b]{3}{*}{ Constituent } & \multirow[b]{3}{*}{ Unit } & \multicolumn{4}{|c|}{ Andesite AGV-2 } & \multicolumn{4}{|c|}{ Granodiorite GSP } \\
\hline & & \multicolumn{2}{|c|}{ Reported } & \multicolumn{2}{|c|}{$\begin{array}{l}\text { USGS Contract } \\
\text { Lab SGS }\end{array}$} & \multicolumn{2}{|c|}{ Reported } & \multicolumn{2}{|c|}{$\begin{array}{c}\text { USGS Contract } \\
\text { Lab SGS }\end{array}$} \\
\hline & & Value & $\begin{array}{l}\text { Standard } \\
\text { deviation }\end{array}$ & $\begin{array}{l}\text { Lab } \\
\text { value }\end{array}$ & $\begin{array}{c}\text { Absolute } \\
\text { percent } \\
\text { difference }\end{array}$ & Value & $\begin{array}{l}\text { Standard } \\
\text { deviation }\end{array}$ & $\begin{array}{l}\text { Lab } \\
\text { value }\end{array}$ & $\begin{array}{c}\text { Absolute percent } \\
\text { difference }\end{array}$ \\
\hline $\mathrm{CO}_{2}$ & $\%$ & - & - & - & - & 0.33 & - & 0.26 & 21 \\
\hline Total C & $\%$ & - & - & 0.04 & - & 0.18 & - & 0.18 & 0 \\
\hline $\mathrm{C}$ in $\mathrm{CO}_{3}{ }^{2-}$ & $\%$ & - & - & 0.01 & - & 0.09 & - & 0.07 & 22 \\
\hline Organic C & $\%$ & - & - & 0.03 & - & 0.09 & - & 0.11 & 22 \\
\hline $\mathrm{Al}$ & $\%$ & 8.95 & 0.11 & 8.83 & 1 & 7.57 & - & 7.65 & 1 \\
\hline $\mathrm{Ca}$ & $\%$ & 3.72 & 0.09 & 3.72 & 0 & 1.5 & - & 1.48 & 1 \\
\hline $\mathrm{Fe}$ & $\%$ & 4.68 & 0.09 & 4.32 & 8 & 2.77 & - & 2.7 & 3 \\
\hline $\mathrm{K}$ & $\%$ & 2.39 & 0.09 & 2.35 & 2 & 4.25 & - & 4.09 & 4 \\
\hline $\mathrm{Mg}$ & $\%$ & 1.08 & 0.02 & 0.95 & 12 & 0.615 & - & 0.55 & 11 \\
\hline $\mathrm{Na}$ & $\%$ & 3.11 & 0.09 & 2.93 & 6 & 1.87 & - & 1.74 & 7 \\
\hline S & $\%$ & - & - & $<0.01$ & - & 0.074 & - & 0.07 & 5 \\
\hline $\mathrm{Ti}$ & $\%$ & 0.63 & 0.13 & 0.58 & 8 & 0.339 & - & 0.35 & 3 \\
\hline $\mathrm{Ag}$ & ppm & - & - & $<1$ & - & 3.07 & - & 3 & 2 \\
\hline As & ppm & - & - & 1 & - & 31.4 & - & 32 & 2 \\
\hline $\mathrm{Ba}$ & ppm & 1,140 & 32 & 1,060 & 7 & 1,310 & - & 1,290 & 2 \\
\hline $\mathrm{Be}$ & ppm & 2.3 & 0.4 & 1.8 & 22 & 1.17 & - & 1.2 & 3 \\
\hline
\end{tabular}


Table 9B. Total digestion results for sediment reference materials Andesite (AGV-2) and Granodiorite (GSP).—Continued

[Accepted reference material concentrations from Smith (1995) and Wilson (1998a, b; 2001). \%, percent; ppm, parts per million; SGS, Société Générale de Surveillance; -, not available]

\begin{tabular}{|c|c|c|c|c|c|c|c|c|c|}
\hline \multirow[b]{3}{*}{ Constituent } & \multirow[b]{3}{*}{ Unit } & \multicolumn{4}{|c|}{ Andesite AGV-2 } & \multicolumn{4}{|c|}{ Granodiorite GSP } \\
\hline & & \multicolumn{2}{|c|}{ Reported } & \multicolumn{2}{|c|}{$\begin{array}{c}\text { USGS Contract } \\
\text { Lab SGS }\end{array}$} & \multicolumn{2}{|c|}{ Reported } & \multicolumn{2}{|c|}{$\begin{array}{c}\text { USGS Contract } \\
\text { Lab SGS }\end{array}$} \\
\hline & & Value & $\begin{array}{l}\text { Standard } \\
\text { deviation }\end{array}$ & $\begin{array}{l}\text { Lab } \\
\text { value }\end{array}$ & $\begin{array}{c}\text { Absolute } \\
\text { percent } \\
\text { difference }\end{array}$ & Value & $\begin{array}{l}\text { Standard } \\
\text { deviation }\end{array}$ & $\begin{array}{l}\text { Lab } \\
\text { value }\end{array}$ & $\begin{array}{c}\text { Absolute percent } \\
\text { difference }\end{array}$ \\
\hline $\mathrm{Bi}$ & ppm & - & - & 0.06 & - & 4.28 & - & 3.88 & 9 \\
\hline Cd & ppm & - & - & $<0.1$ & - & 0.227 & - & 0.2 & 12 \\
\hline $\mathrm{Ce}$ & ppm & 68 & 3 & 67 & 1 & 405 & - & 416 & 3 \\
\hline Co & ppm & 16 & 1 & 15.3 & 4 & 6.36 & - & 5.9 & 7 \\
\hline $\mathrm{Cr}$ & $\mathrm{ppm}$ & 17 & 2 & 9 & 47 & 16.6 & - & 15 & 10 \\
\hline Cs & ppm & 1.16 & 0.08 & $<5$ & - & $<5$ & - & $<5$ & - \\
\hline $\mathrm{Cu}$ & ppm & 53 & 4 & 48.3 & 9 & 31.3 & - & 33.3 & 6 \\
\hline $\mathrm{Ga}$ & ppm & 20 & 1 & 21.4 & 7 & 22.2 & - & 21.9 & 1 \\
\hline $\mathrm{Hg}$ & ppm & - & - & 0.01 & - & 0.26 & - & 0.26 & 0 \\
\hline In & $\mathrm{ppm}$ & - & - & 0.04 & - & 0.04 & - & 0.04 & 0 \\
\hline $\mathrm{La}$ & ppm & 38 & 1 & 38 & 0 & 173 & - & 172 & 1 \\
\hline $\mathrm{Li}$ & ppm & 11 & - & 10 & 9 & 34 & - & 33 & 3 \\
\hline $\mathrm{Mn}$ & $\mathrm{ppm}$ & 770 & 20 & 688 & 11 & 281 & - & 342 & 22 \\
\hline Mo & ppm & - & - & 2.62 & - & 1.31 & - & 1.38 & 5 \\
\hline $\mathrm{Nb}$ & ppm & 15 & 1 & 14.1 & 6 & 18.6 & - & 22.3 & 20 \\
\hline $\mathrm{Ni}$ & ppm & 19 & 3 & 16.8 & 12 & 11.5 & - & 12.1 & 5 \\
\hline $\mathrm{P}$ & $\mathrm{ppm}$ & 2,100 & 100 & 1,990 & 5 & 1230 & - & 1,140 & 7 \\
\hline $\mathrm{Pb}$ & ppm & 13 & 1 & 22 & 69 & 40.4 & - & 37 & 8 \\
\hline $\mathrm{Rb}$ & ppm & 68.6 & 2.3 & 68.2 & 1 & 228 & - & 231 & 1 \\
\hline $\mathrm{Sb}$ & $\mathrm{ppm}$ & 0.6 & - & 0.76 & 27 & 0.877 & - & 0.83 & 5 \\
\hline Sc & $\mathrm{ppm}$ & 13 & 1 & 11.5 & 12 & 6.23 & - & 6 & 4 \\
\hline Sn & ppm & 2.3 & 0.4 & 2 & 13 & 4.72 & - & 4.7 & 0 \\
\hline $\mathrm{Sr}$ & $\mathrm{ppm}$ & 658 & 17 & 588 & 11 & 226 & - & 205 & 9 \\
\hline $\mathrm{Te}$ & $\mathrm{ppm}$ & - & - & $<0.1$ & - & 4.07 & - & 3.9 & 4 \\
\hline Th & ppm & 6.1 & 0.6 & 6.2 & 2 & 104 & - & 109 & 5 \\
\hline $\mathrm{Tl}$ & $\mathrm{ppm}$ & 0.27 & - & 0.3 & 11 & 2.07 & - & 1.9 & 8 \\
\hline $\mathrm{U}$ & $\mathrm{ppm}$ & 1.88 & 0.16 & 1.9 & 1 & 2.27 & - & 2.2 & 3 \\
\hline $\mathrm{V}$ & ppm & 120 & 5 & 112 & 7 & 73.3 & - & 68 & 7 \\
\hline W & ppm & - & - & 0.7 & - & 6.65 & - & 6.7 & 1 \\
\hline $\mathrm{Y}$ & ppm & 20 & 1 & 19.5 & 3 & 25.5 & - & 25.4 & 0 \\
\hline $\mathrm{Zn}$ & ppm & 86 & 8 & 81 & 6 & 117 & - & 117 & 0 \\
\hline
\end{tabular}


Table 10. Sediment reference material results for U.S. Environmental Protection Agency 3050 partial digestion; replicate runs listed for each reference material.

[Accepted reference material concentrations from National Institute of Standards and Technology (2003). Blank cell indicates value was not reported. \%, percent; ppm, parts per million]

\begin{tabular}{|c|c|c|c|c|c|c|c|c|c|}
\hline \multirow[b]{2}{*}{ Constituent } & \multirow[b]{2}{*}{ Units } & \multicolumn{3}{|c|}{2709} & \multicolumn{3}{|c|}{2710} & \multicolumn{2}{|c|}{2711} \\
\hline & & $\begin{array}{c}\text { Laboratory } \\
\text { value }\end{array}$ & $\begin{array}{c}\text { Laboratory } \\
\text { replicate } \\
\text { value }\end{array}$ & $\begin{array}{c}\text { Reported } \\
\text { value } \\
\text { range }\end{array}$ & $\begin{array}{l}\text { Laboratory } \\
\text { value }\end{array}$ & $\begin{array}{c}\text { Laboratory } \\
\text { replicate } \\
\text { value }\end{array}$ & $\begin{array}{c}\text { Reported } \\
\text { value } \\
\text { range }\end{array}$ & $\begin{array}{c}\text { Laboratory } \\
\text { value }\end{array}$ & $\begin{array}{c}\text { Reported } \\
\text { value } \\
\text { range }\end{array}$ \\
\hline $\mathrm{Al}$ & $\%$ & 3.15 & 3.33 & $2-3.1$ & 2.51 & 2.52 & $1.2-2.6$ & 2.55 & $1.2-2.3$ \\
\hline $\mathrm{Ca}$ & $\%$ & 1.43 & 1.54 & $1.4-1.7$ & 0.43 & 0.444 & $0.38-0.48$ & 2.27 & $2.0-2.5$ \\
\hline $\mathrm{Fe}$ & $\%$ & 3.03 & 3.09 & $2.5-3.3$ & 2.93 & 2.19 & $2.2-3.2$ & 2.03 & $1.7-2.6$ \\
\hline K & $\%$ & 0.399 & 0.42 & $0.26-0.37$ & 0.525 & 0.525 & $0.37-0.50$ & 0.507 & $0.26-0.53$ \\
\hline $\mathrm{Mg}$ & $\%$ & 1.35 & 1.36 & $1.2-1.5$ & 0.592 & 0.567 & $0.43-0.60$ & 0.828 & $0.72-0.89$ \\
\hline $\mathrm{Na}$ & $\%$ & 0.075 & 0.077 & $0.063-0.11$ & 0.067 & 0.066 & $0.049-0.062$ & 0.037 & $0.02-0.029$ \\
\hline $\mathrm{P}$ & $\%$ & 0.055 & 0.055 & $0.05-0.07$ & 0.092 & 0.088 & $0.106-0.11$ & 0.077 & $0.06-0.09$ \\
\hline $\mathrm{SO}_{4}^{2-}$ & $\%$ & 0.083 & 0.087 & & 0.234 & 0.22 & & 0.039 & \\
\hline $\mathrm{Ti}$ & $\%$ & 0.058 & 0.061 & $0.03-0.04$ & 0.131 & 0.126 & $0.092-0.11$ & 0.076 & $0.039-0.048$ \\
\hline Ag & ppm & $<2$ & $<2$ & & 7.77 & 9.55 & & $<2$ & \\
\hline As & ppm & $<30$ & $<30$ & $<20$ & 637 & 615 & $490-600$ & 121 & $88-110$ \\
\hline $\mathrm{Ba}$ & ppm & 413 & 449 & $392-400$ & 357 & 373 & $300-400$ & 223 & $170-260$ \\
\hline $\mathrm{Be}$ & ppm & $<1$ & $<1$ & & $<1$ & $<1$ & & $<1$ & \\
\hline $\mathrm{Cd}$ & ppm & $<2$ & $<2$ & $<1$ & 24.1 & 23.8 & $13-26$ & 40.7 & $32-46$ \\
\hline Ce & ppm & 36.1 & 41.6 & & 41.2 & 45.6 & & 59.6 & \\
\hline Co & ppm & 11.9 & 12.3 & $10.0-15$ & 7.86 & 7.83 & $6.3-12$ & 8.08 & $7-12$ \\
\hline $\mathrm{Cr}$ & $\mathrm{ppm}$ & 78.7 & 83 & $60-115$ & 22 & 21.7 & $15-23$ & 26.8 & $15-25$ \\
\hline $\mathrm{Cu}$ & ppm & 35 & 39.1 & $26-40$ & 3,080 & 3,010 & $2,400-3,400$ & 126 & $91-110$ \\
\hline $\mathrm{Eu}$ & ppm & $<2$ & $<2$ & & $<2$ & $<2$ & & $<2$ & \\
\hline $\mathrm{La}$ & ppm & 16.8 & 18 & & 21.5 & 21.5 & & 30 & \\
\hline $\mathrm{Li}$ & ppm & 37.7 & 41 & & 30.6 & 31.3 & & 19 & \\
\hline Mn & ppm & 528 & 536 & $360-600$ & 8,650 & 8,410 & $6,200-9,000$ & 581 & $400-620$ \\
\hline Mo & ppm & $<2$ & $<2$ & $<2$ & 9.59 & 12.1 & $13-27$ & $<2$ & $<2$ \\
\hline $\mathrm{Nb}$ & ppm & $<4$ & $<4$ & & $<4$ & $<4$ & & $<4$ & \\
\hline $\mathrm{Nd}$ & ppm & 14.5 & 13.3 & & $<4$ & $<4$ & & 11.3 & \\
\hline $\mathrm{Ni}$ & ppm & 78.1 & 79.4 & $65-90$ & 10.4 & 10 & $8.8-15$ & 17 & $14-20$ \\
\hline $\mathrm{Pb}$ & ppm & $<20$ & 28.5 & $12-18$ & 5,440 & 5,220 & $4,300-7,000$ & 1,200 & $930-1,500$ \\
\hline Sc & ppm & 7.85 & 8.33 & & 4.74 & 4.85 & & 4.77 & \\
\hline $\mathrm{Sr}$ & ppm & 107 & 114 & $100-112$ & 110 & 113 & $94-110$ & 55.4 & $48-55$ \\
\hline Th & ppm & 8.3 & 8.85 & & 10.5 & 11.1 & & 10.8 & \\
\hline V & ppm & 79.2 & 81.7 & $51-70$ & 54 & 53.3 & $37-50$ & 57.2 & $34-50$ \\
\hline $\mathrm{Y}$ & ppm & 11 & 11.8 & & 13.6 & 13.4 & & 18.8 & \\
\hline $\mathrm{Yb}$ & ppm & 1.09 & 1.2 & & 1.09 & 1.08 & & 1.87 & \\
\hline $\mathrm{Zn}$ & $\mathrm{ppm}$ & 95.8 & 157 & $87-120$ & 6,190 & 5,960 & $5,200-6,900$ & 366 & $290-340$ \\
\hline
\end{tabular}




\section{Sediment Leachate}

One replicate sample from site OYM-14-W was analyzed for sediment leachate. The replicate analysis indicates that several elements have relative percentage differences between the sample and replicate greater than 20 percent (table 11). The difference may represent variability owing to heterogeneity within a sediment sample. More replicate samples would be needed to statistically quantify the variability for each element.
One replicate sample from the sediment leachate from site OYM-10-T was analyzed for strontium and strontium isotopic value. The samples had the same strontium concentration of 33.4 micrograms per liter $(\mu \mathrm{g} / \mathrm{L})$ and strontium isotope ratios of 0.71174 and 0.71178 . The difference in strontium isotopes ( 0.00004 or 0.01 percent) is greater than the 2-sigma uncertainty presented by the USGS National Research Program Laboratory in Menlo Park, Calif. (0.000024).

Table 11. Results of sediment leachate replicate analyses for site OYM-14-W.

[Bold values indicate the percentage difference is greater than 20 percent; $\mathrm{mg} / \mathrm{L}$, milligrams per liter; $\mu \mathrm{g} / \mathrm{L}$, micrograms per liter; NA, not determined]

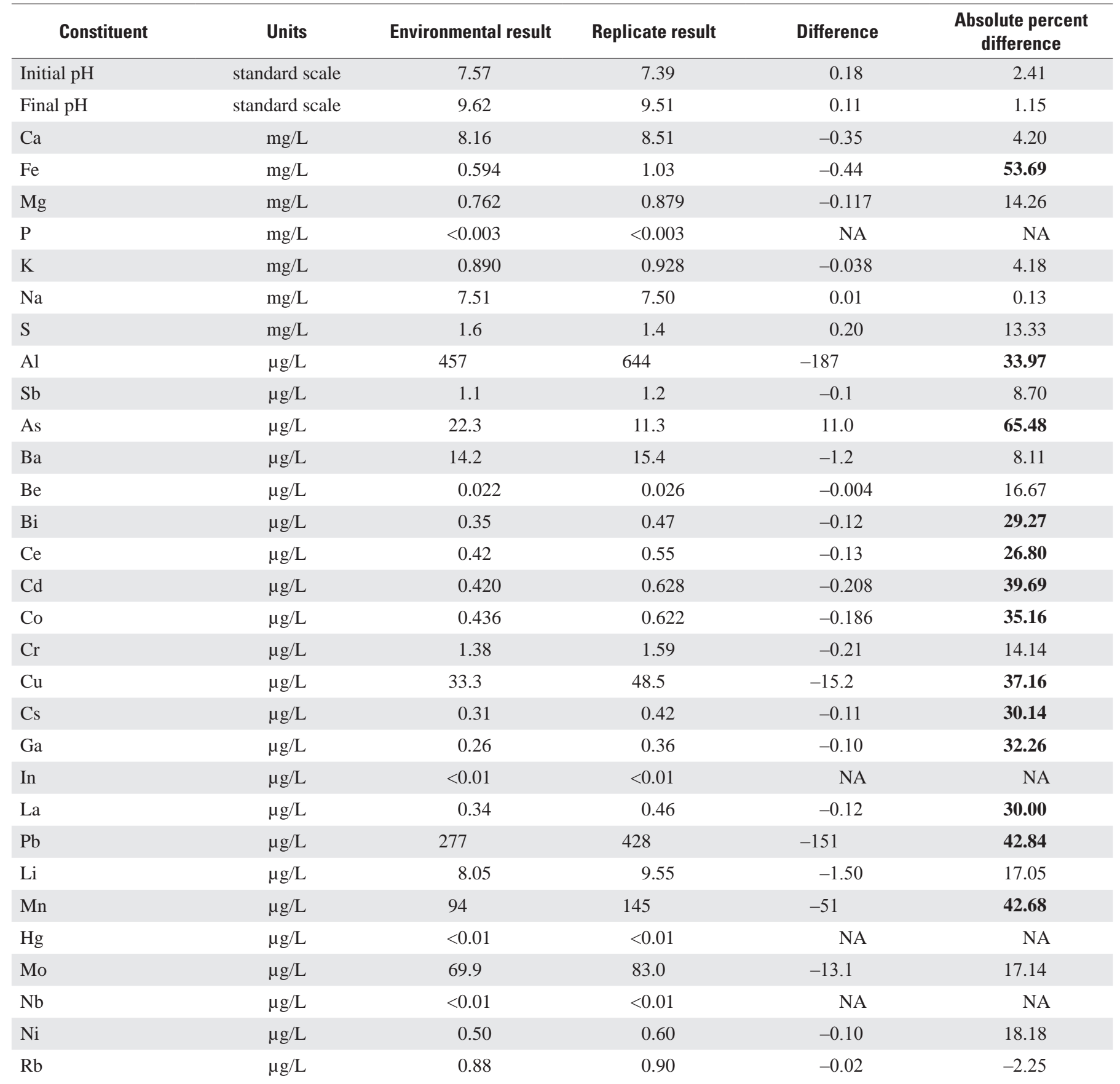


Table 11. Results of sediment leachate replicate analyses for site OYM-14-W.-Continued

[Bold values indicate the percentage difference is greater than 20 percent; mg/L, milligrams per liter; $\mu \mathrm{g} / \mathrm{L}$, micrograms per liter; NA, not determined]

\begin{tabular}{lccccc}
\hline Constituent & Units & Environmental result & Replicate result & Difference & $\begin{array}{c}\text { Absolute percent } \\
\text { difference }\end{array}$ \\
\hline $\mathrm{Sc}$ & $\mu \mathrm{g} / \mathrm{L}$ & 0.52 & 0.67 & -0.15 & $\mathbf{2 5 . 2 7}$ \\
$\mathrm{Se}$ & $\mu \mathrm{g} / \mathrm{L}$ & 0.07 & 0.08 & -0.01 & 13.33 \\
$\mathrm{Ag}$ & $\mu \mathrm{g} / \mathrm{L}$ & 0.024 & 0.025 & -0.001 & 4.08 \\
$\mathrm{Sr}$ & $\mu \mathrm{g} / \mathrm{L}$ & 40.5 & 40.9 & -0.4 & 0.98 \\
$\mathrm{Te}$ & $\mu \mathrm{g} / \mathrm{L}$ & $<0.01$ & $<0.01$ & $\mathrm{NA}$ & $\mathrm{NA}$ \\
$\mathrm{Th}$ & $\mu \mathrm{g} / \mathrm{L}$ & 0.05 & 0.08 & -0.03 & $\mathbf{4 6 . 1 5}$ \\
$\mathrm{Sn}$ & $\mu \mathrm{g} / \mathrm{L}$ & 0.21 & 0.07 & 0.14 & $\mathbf{1 0 0 . 0 0}$ \\
$\mathrm{Ti}$ & $\mu \mathrm{g} / \mathrm{L}$ & 10.9 & 17.7 & -6.8 & $\mathbf{4 7 . 5 5}$ \\
$\mathrm{Tl}$ & $\mu \mathrm{g} / \mathrm{L}$ & 0.015 & 0.011 & 0.004 & $\mathbf{3 0 . 7 7}$ \\
$\mathrm{W}$ & $\mu \mathrm{g} / \mathrm{L}$ & 0.30 & 0.37 & -0.07 & $\mathbf{2 0 . 9 0}$ \\
$\mathrm{U}$ & $\mu \mathrm{g} / \mathrm{L}$ & 0.086 & 0.106 & -0.020 & $\mathbf{2 0 . 8 3}$ \\
$\mathrm{V}$ & $\mu \mathrm{g} / \mathrm{L}$ & 0.94 & 1.24 & -0.30 & $\mathbf{2 7 . 5 2}$ \\
$\mathrm{Y}$ & $\mu \mathrm{g} / \mathrm{L}$ & 0.132 & 0.185 & -0.053 & $\mathbf{3 3 . 4 4}$ \\
$\mathrm{Zn}$ & $\mu \mathrm{g} / \mathrm{L}$ & 511 & 842 & -331 & $\mathbf{4 8 . 9 3}$ \\
\hline
\end{tabular}

\section{Groundwater Elevation}

\section{Spatial}

Groundwater elevation was measured between 2014 and 2017 at 29 groundwater sites (fig. 2). Groundwater elevation was generally highest in the southern and western parts of the study area, which also have higher ground surface elevations. Groundwater flow direction is generally toward the northeast in the study area. There was a steep water-level gradient over a small area in the north-central part of the study area where measured groundwater elevation changes by more than $200 \mathrm{ft}$ in less than 0.25 miles. The steep gradient is located beneath surficial Quaternary-fill geologic units, where no structural feature is mapped, but the gradient coincides with the projection of the Old Yuma Fault from Lipman (1993).

Chon and others (2016) measured geophysical data in the area near the large change in groundwater-level elevation using transient electromagnetics (TEM) and reported higher resistivity at depth on the northwestern side of the projected Old Yuma Fault than on the southeastern side. The more conductive area was above the resistive zone at depth on the northwestern side and may relate to the shallow groundwater-level elevations. On the southeastern side, the resistive zone was at the surface, with the more conductive area located below the resistive zone (Chon and others, 2016). The displacement of the conductive zones may be due to the presence of the Old Yuma Fault beneath the basin fill.

Some of the wells show evidence of confined or semiconfined groundwater conditions. Well D-13-12 10BAC3 (well 13 in table 1 and fig. 2) was drilled during this study and cuttings were collected during drilling (described in table 12). The well was drilled using air rotary, which may break up rock from different intervals to a greater degree, depending on the pressure in that interval; therefore, the descriptions of competency in table 12 are not representative of the original rock material. The well was drilled through $27 \mathrm{ft}$ of unconsolidated material followed by rhyodacite-rhyolite flow material that may be related to the Tertiary Safford Dacite units of Lipman (1993), which are present on the hill to the south and west of the well. A distinct change to obsidian was noted starting around 300 to $440 \mathrm{ft}$. The drillers encountered a small amount of water above $300 \mathrm{ft}$ during drilling, which dried up quickly, and around $440 \mathrm{ft}$ they had to increase drilling pressure. Below the resistant layer, water was encountered and the total well was drilled to $687 \mathrm{ft}$. The static water level rose to an elevation of 2,224.6 ft (148.3 feet below land surface, table 13). To the east, well D-13-12 10BAC2 was drilled to the same total depth below the surface and the water level in that well was at an elevation of 1,928.3 ft (452.0 ft below land surface, table 13).

The water-level elevation within the inclined shaft of the Old Yuma Mine was determined to be between 2,400 and $2,450 \mathrm{ft}$, based on the groundwater elevation map (fig. 2). The elevation of the surface at the top of the mine shaft is $2,575 \mathrm{ft}$. The shaft is inclined at $43^{\circ}$ from horizontal and a total depth of $300 \mathrm{ft}$ was reported when the shaft was created. The $200-\mathrm{ft}$ level is not saturated and the shaft has collapsed below the 200-ft level (National Park Service, 2010). The geometry of the shaft and the groundwater level estimation places the water table within the collapsed portion of the lower $100 \mathrm{ft}$ of the mine shaft. Calculating the vertical distance from the land surface, the water level is below 2,440 ft. There may be 
Table 12. Well-cutting descriptions from well D-13-12 10BAC3.

[Samples are numbered such that 1 is at the surface and larger numbers represent progressively deeper samples; mm, millimeter]

\begin{tabular}{|c|c|c|c|}
\hline $\begin{array}{l}\text { Drilling } \\
\text { sample } \\
\text { number }\end{array}$ & Description & Comments & $\begin{array}{l}\text { Depth, } \\
\text { in feet }\end{array}$ \\
\hline 1 & $\begin{array}{l}\text { Grayish-colored finely porphyritic rhyodacite-rhyolite with } 1 \mathrm{~mm} \text { phenocrysts of } \\
\text { plagioclase and biotite in a granular microcrystalline groundmass; portions of } \\
\text { groundmass appear partly aphanitic }\end{array}$ & Rhyodacite-rhyolite, porphyritic & $0-27$ \\
\hline 2 & $\begin{array}{l}\text { Light gray to white rhyolitic altered/weathered pumiceous tuff; weathered to clays, } \\
\text { devitrified glassy cryptocrystalline matrix, phenocryst altered to kaolin; altered } \\
\text { crystal-rich clusters in clayey matrix; rock is friable, crushes in hand }\end{array}$ & Siliceous weathered tuff & $27-63$ \\
\hline 3 & $\begin{array}{l}\text { Light tan to pinkish-gray siliceous altered rock (rhyodacitic to rhyolitic); pheno- } \\
\text { crysts of feldspar, minor biotite; biotite is altered }\end{array}$ & Rhyodacite-rhyolite, porphyritic & $63-72$ \\
\hline 4 & $\begin{array}{l}\text { Pinkish-tan to tannish-gray rhyodacitic to rhyolitic rock with } 0.5-1 \mathrm{~mm} \text { pheno- } \\
\text { crysts of plagioclase, minor scattered biotite }\end{array}$ & Rhyodacite-rhyolite, porphyritic & \\
\hline 5 & Same as above & Rhyodacite-rhyolite, porphyritic & \\
\hline 6 & Same as above & Rhyodacite-rhyolite, porphyritic & \\
\hline 7 & $\begin{array}{l}\text { Same as above; fragments show some secondary white quartz stringers irregularly } \\
\text { crosscutting material }\end{array}$ & Rhyodacite-rhyolite, porphyritic & \\
\hline 8 & Same as above; clear intergranular groundmass (microcrystalline) & Rhyodacite-rhyolite, porphyritic & \\
\hline 9 & Same as above & Rhyodacite-rhyolite, porphyritic & \\
\hline 10 & $\begin{array}{l}\text { Same as above; fragments have a planar (flat) habit, are dark tan colored, and } \\
\text { interspersed with some light-gray-colored rhyolitic pieces }\end{array}$ & Rhyodacite-rhyolite, porphyritic & \\
\hline 11 & Same as above; some clear quartz crystal fragments & Rhyodacite-rhyolite, porphyritic & \\
\hline 12 & Same as above; irregular fine-grained pieces and irregular crystal-rich clusters & Rhyodacite-rhyolite, porphyritic & end 286 \\
\hline 13 & $\begin{array}{l}\text { Same as above; shows some very dark colored aphanitic fragments with pheno- } \\
\text { crysts in aphanitic matrix }\end{array}$ & Mixed glassy material, rhyolitic & $\begin{array}{l}\text { start } \\
286\end{array}$ \\
\hline 14 & $\begin{array}{l}\text { Mixed obsidian material (dark gray to black in color); glassy fragments mixed with } \\
\text { some rhyodacite-rhyolite with phenocrysts }\end{array}$ & $\begin{array}{l}\text { Obsidian mixed with rhyolitic } \\
\text { material }\end{array}$ & \\
\hline 15 & $\begin{array}{l}\text { Obsidian-predominant fragments; glassy to slightly devitrified (indicating flow } \\
\text { margin?) }\end{array}$ & Obsidian & \\
\hline 16 & $\begin{array}{l}\text { Same as above; mixed rhyodacite-rhyolite containing plagioclase and biotite } \\
\text { phenocrysts in aphanitic glassy matrix }\end{array}$ & $\begin{array}{l}\text { Obsidian mixed with rhyolitic } \\
\text { material }\end{array}$ & \\
\hline 17 & $\begin{array}{l}\text { Mixed obsidian material; altered glassy fragments mixed with some rhyodacite- } \\
\text { rhyolite with phenocrysts }\end{array}$ & $\begin{array}{l}\text { Obsidian mixed with rhyolitic } \\
\text { material }\end{array}$ & \\
\hline 18 & Same as above; devitrified, altered rhyolitic material & $\begin{array}{l}\text { Obsidian mixed with rhyolitic } \\
\text { material }\end{array}$ & $\sim 440$ \\
\hline 19 & $\begin{array}{l}\text { Pumiceous tuff; material crystal-rich with altered biotite and plagioclase in altered } \\
\text { microcrystalline matrix; crumbles in hand; similar to sample number } 2\end{array}$ & Tuffaceous lens & \\
\hline 20 & $\begin{array}{l}\text { Light to medium gray, pinkish-tan rhyodacite-rhyolite with plagioclase and biotite } \\
\text { phenocrysts in aphanitic matrix }\end{array}$ & Rhyodacite-rhyolite, porphyritic & \\
\hline 21 & Same as above & Rhyodacite-rhyolite, porphyritic & \\
\hline 22 & Same as above & Rhyodacite-rhyolite, porphyritic & \\
\hline 23 & Same as above & Rhyodacite-rhyolite, porphyritic & $\sim 560$ \\
\hline 24 & Same as above & Rhyodacite-rhyolite, porphyritic & \\
\hline
\end{tabular}


Table 13. Water-level measurements.

[ASL, above sea level, BLS, below land surface; R, recently pumped prior to measurement; -, not recently pumped]

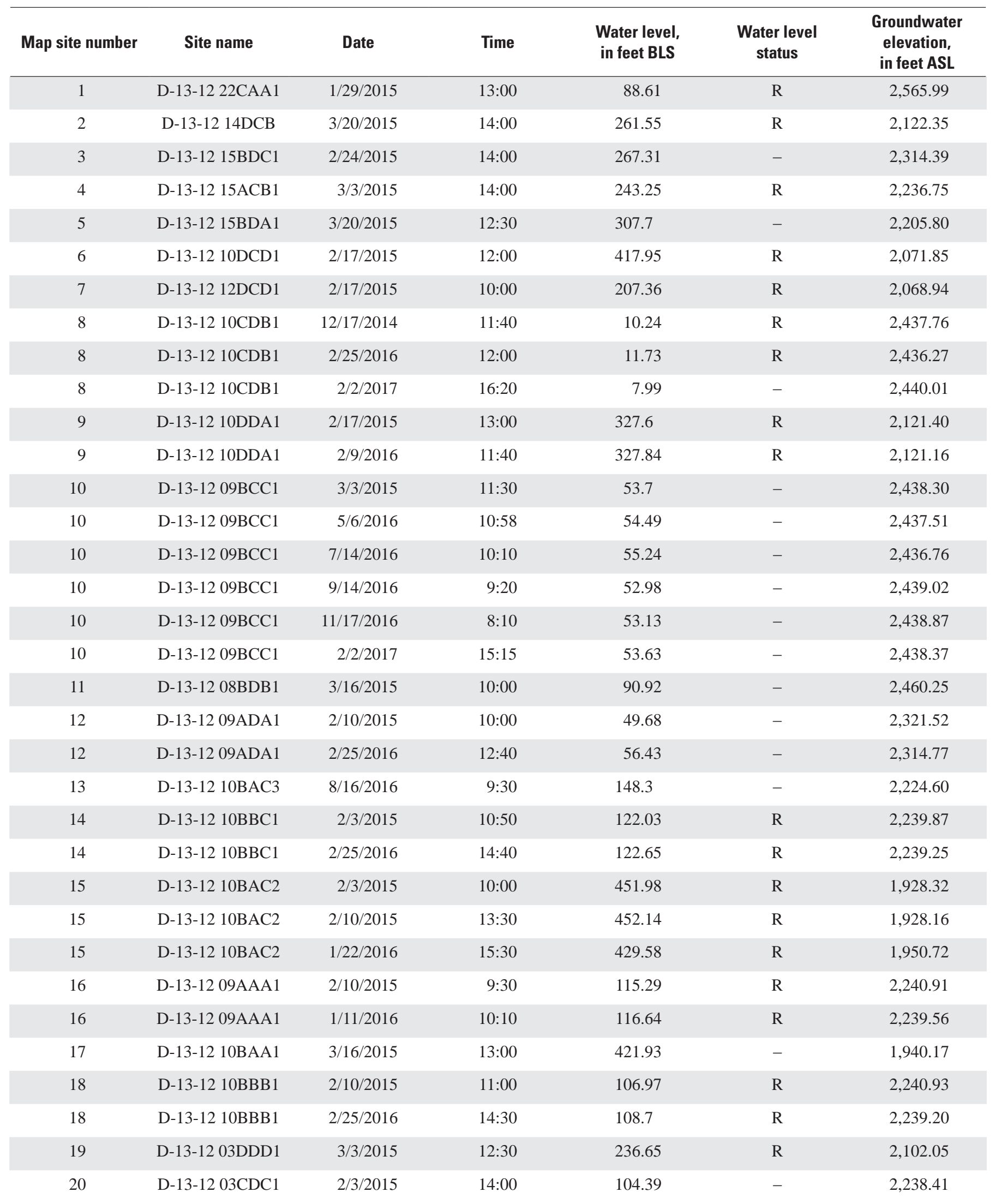


Table 13. Water-level measurements.-Continued

[ASL, above sea level, BLS, below land surface; R, recently pumped prior to measurement; -, not recently pumped]

\begin{tabular}{|c|c|c|c|c|c|c|}
\hline Map site number & Site name & Date & Time & $\begin{array}{l}\text { Water level, } \\
\text { in feet BLS }\end{array}$ & $\begin{array}{c}\text { Water level } \\
\text { status }\end{array}$ & $\begin{array}{c}\text { Groundwater } \\
\text { elevation, } \\
\text { in feet ASL }\end{array}$ \\
\hline 21 & D-13-12 03DCD1 & 3/3/2015 & $12: 00$ & 238.79 & $\mathrm{R}$ & $2,102.61$ \\
\hline 22 & D-13-12 04DCD & $1 / 23 / 2015$ & $12: 00$ & 138.99 & - & 2,246.31 \\
\hline 22 & D-13-12 04DCD & 2/8/2016 & $10: 38$ & 138.77 & - & $2,246.53$ \\
\hline 22 & D-13-12 04DCD & 9/14/2016 & $9: 35$ & 135.07 & - & $2,250.23$ \\
\hline 22 & D-13-12 04DCD & $11 / 16 / 2016$ & $12: 50$ & 133.01 & - & $2,252.29$ \\
\hline 22 & D-13-12 04DCD & $2 / 2 / 2017$ & $15: 45$ & 133.01 & - & 2,252.29 \\
\hline 23 & D-13-12 03DCA1 & $2 / 24 / 2015$ & $11: 30$ & 228.14 & $\mathrm{R}$ & $2,108.26$ \\
\hline 26 & D-13-12 03DBD1 & 3/16/2015 & $12: 00$ & 207.63 & $\mathrm{R}$ & $2,102.37$ \\
\hline 27 & D-13-12 04DAD1 & $2 / 24 / 2015$ & $10: 00$ & 82 & - & $2,238.50$ \\
\hline 28 & D-13-12 03DBA1 & $1 / 22 / 2016$ & $14: 49$ & 190.09 & - & $2,102.21$ \\
\hline 28 & D-13-12 03DBA1 & 1/29/2016 & 11:05 & 189.87 & $\mathrm{R}$ & $2,102.43$ \\
\hline 29 & D-13-12 03BCC1 & 2/4/2016 & $11: 00$ & 149.72 & - & $2,151.58$ \\
\hline
\end{tabular}

local anomalies in the groundwater elevation near the mine and the Old Yuma Fault that were not documented during this study because of a lack of groundwater wells near the mine. The TEM data indicate a lower resistivity zone below an elevation of about 2,300 ft to the south and east of the mine and below about 2,100 ft at a station closer to the mine, which may represent either the groundwater elevation or mine workings (Chon and others, 2016). Less resistive zones are shallower (approximately 2,300 ft) at geophysical stations to the north and west of the Old Yuma Mine. Additional data would improve estimates of groundwater elevation near the mine.

\section{Temporal}

Groundwater levels were measured multiple times over multiple years in 10 of the 29 wells (table 13). The average water-level difference between the highest and lowest value for the wells with multiple measurements was $4.54 \mathrm{ft}$, with the greatest change of $22.56 \mathrm{ft}$ at D-13-12 10BAC2 and the smallest change of $0.22 \mathrm{ft}$ at D-13-12 03DBA1. A previous study measured the water level at site D-13-12 09ADA1 (site number 12) in 2011 to be $52.8 \mathrm{ft}$ below the land surface (URS Corporation, 2012), which is between the two water-level measurements made at that well during this study.

Continuous groundwater levels were recorded in two wells: D-13-12 09BCC1 and D-13-12 04DCD. Historical water-level measurements are available starting in 1949 for D-13-12 04DCD (U.S. Geological Survey, 2017b) and the difference between the highest and lowest water level over the measurement period was $22 \mathrm{ft}$ (fig. 3A). Over the 2-year study period from 2015 to 2017 there was a 6-ft water-level increase at D-13-12 04DCD (fig. 3A). At D-13-12 09BCC1 there was a 2-ft water-level increase over a 3-month period (fig. 3B).

\section{Groundwater Geochemistry}

\section{General Chemistry}

Eight wells were sampled for a comprehensive geochemical suite of analyses. The temperature of the samples ranged from 25.8 to $30.2^{\circ} \mathrm{C}$, $\mathrm{pH}$ ranged from 6.8 to 7.8 , specific conductance ranged from 547 to 3,020 microsiemens per centimeter $(\mu \mathrm{S} / \mathrm{cm})$, and dissolved oxygen ranged from 1 to 6.2 milligrams per liter (mg/L). Major ion composition of the groundwater samples varied across the study area. Some wells were dominated by major cation type of calcium (D-13-12 09AAA1, 03CCA1, and 04DCD) and some sodium (D-13-12 10BAC2, 10DDA1, and 10BAC3), and major anion type bicarbonate (D-13-12 09AAA1, 10BAC2, 03DBA1, and 10DDA1) and chloride (D-13-12 04DCD) (figs. 1B and 4). D-13-12 03BCC1 had mixed water type with no dominant ion. 


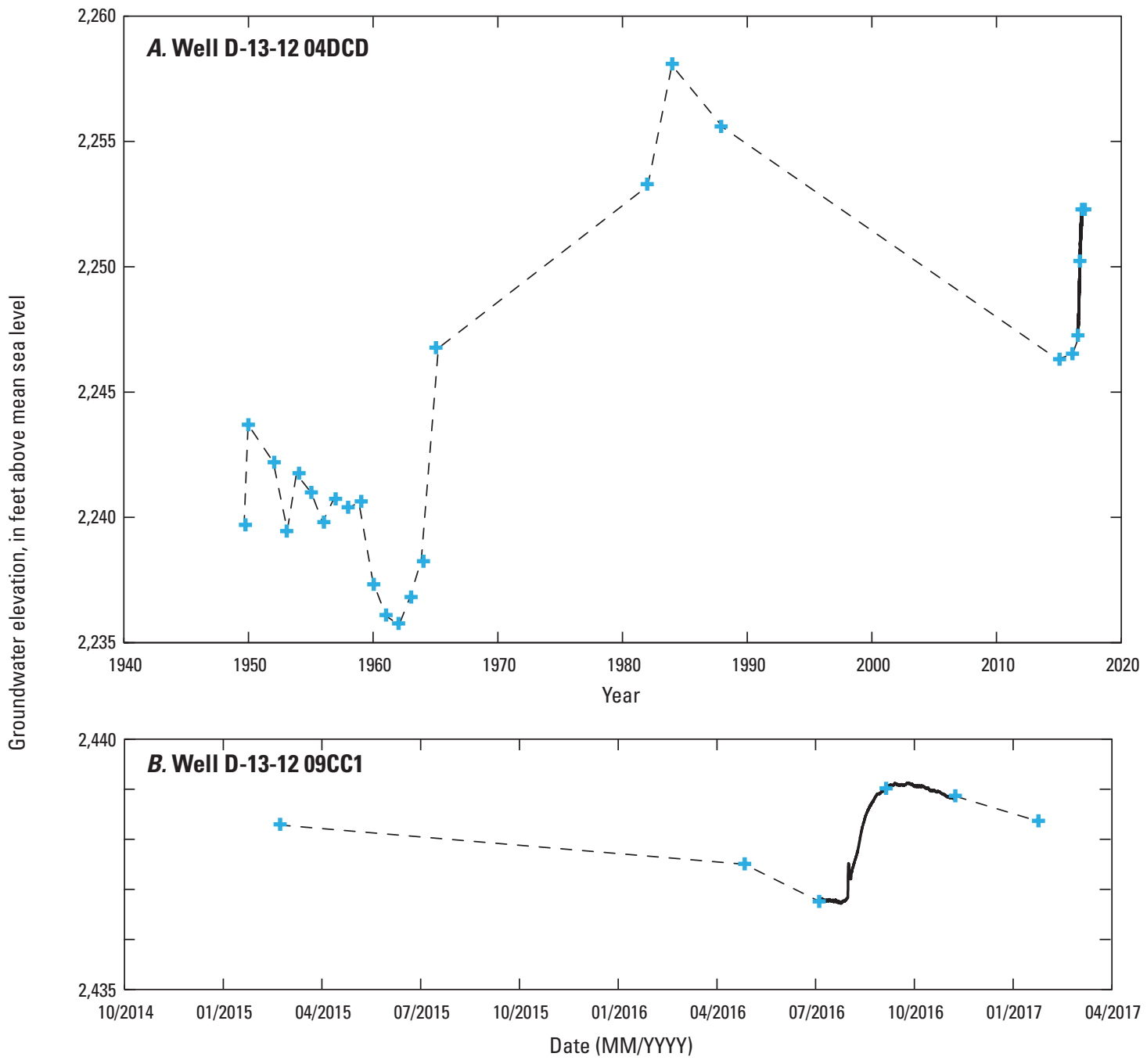

Figure 3. Groundwater level measured with a pressure transducer at two well sites. A, D-13-12 04DCD and B, D-13-12 09BCC1. Blue crosses show discrete water-level measurements. Solid black lines plot hourly measurements; dashed black lines connect discrete measurements. 


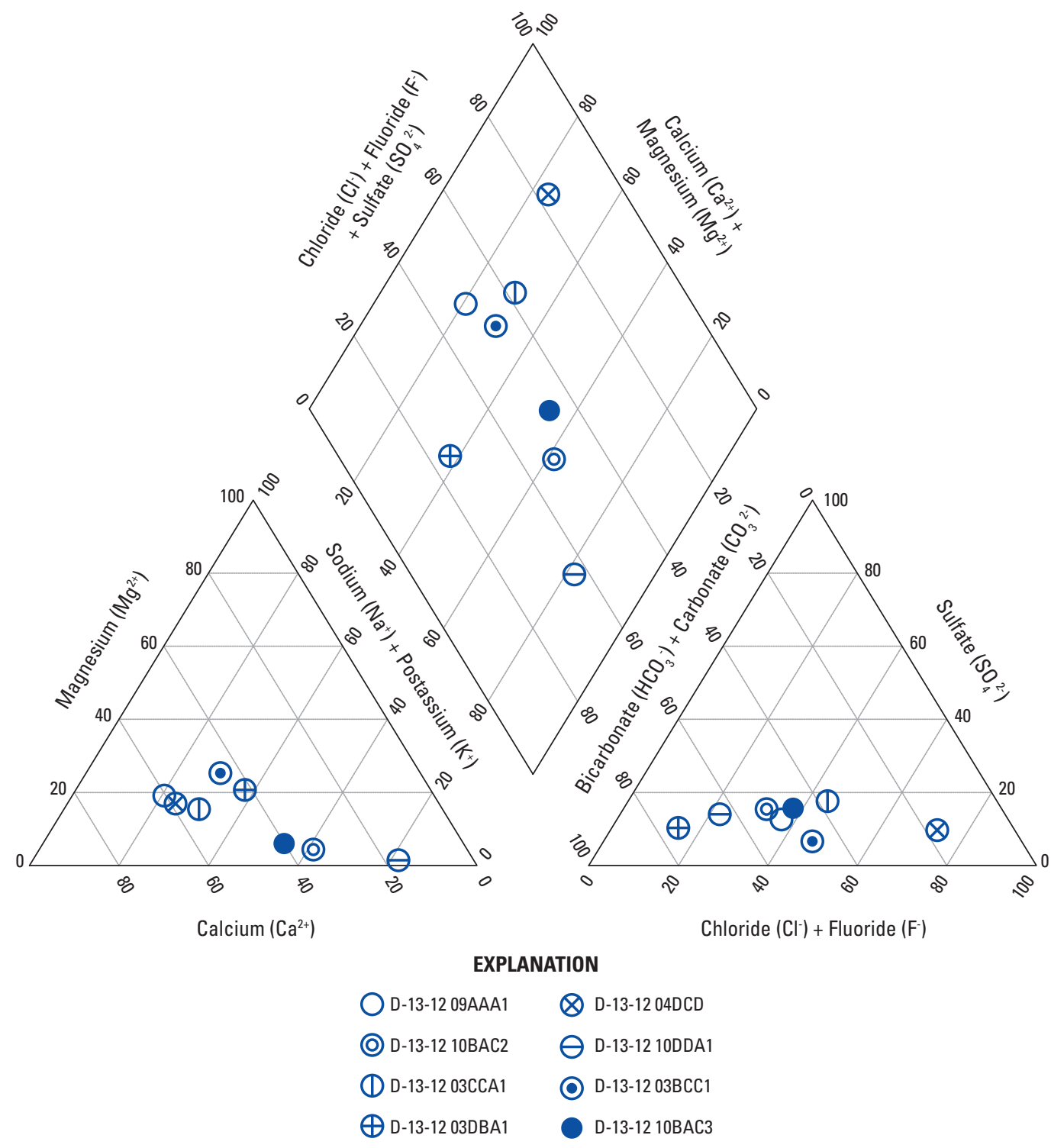

Figure 4. Piper diagram plotting the major ion proportion of groundwater samples. All axes plot relative concentrations, in percent.

Only one sample (D-13-12 03DBA1) had a value that exceeded the EPA primary drinking water standard for arsenic (10.7 $\mu \mathrm{g} / \mathrm{L}$ and $10 \mu \mathrm{g} / \mathrm{L}$, respectively). Sample D-13-12 04DCD exceeded the EPA secondary drinking water standard for chloride, iron, manganese, and total dissolved solids.

However, this well does not have a pump installed and is not currently used to supply drinking water. Two other samples (D-13-12 09AAA1 and 03CCA1) had a total dissolved solids concentration greater than the EPA secondary drinking water standard of $500 \mathrm{mg} / \mathrm{L}$.

Perchlorate $\left(\mathrm{ClO}_{4}^{-}\right)$can be used as an indicator of the use of explosives (Smith and others, 2015), potentially from nearby mining activities, but is also known to occur naturally (Plummer and others, 2006). Reported concentrations of perchlorate in groundwater associated with blasting for mining activities at a different mine were variable and had a maximum value of $157 \mu \mathrm{g} / \mathrm{L}$ (Smith and others, 2015). Perchlorate concentrations ranging from 0.12 to $1.8 \mu \mathrm{g} / \mathrm{L}$ were measured in pre-anthropogenic samples from remote parts of the Middle Rio Grande Basin in New Mexico (Plummer and others, 2006). Concentrations reported here ranged from 0.67 to $1.48 \mu \mathrm{g} / \mathrm{L}$ and are similar for samples containing tritium and those without detectable tritium, indicating that the perchlorate measured in the samples is likely naturally occurring. All perchlorate concentrations in this study are less than the EPA interim health advisory value of $15 \mu \mathrm{g} / \mathrm{L}$ (U.S. Environmental Protection Agency, 2008). 


\section{Isotopic Analysis}

Stable isotopes of oxygen and hydrogen can be used to understand elevation, season, and evaporation effects of water contributing to groundwater. Groundwater samples from this study were compared with the global meteoric water line (GMWL; Craig, 1961) and local meteoric water line (LMWL) derived from precipitation collected near the University of Arizona in Tucson (Eastoe and Dettman, 2016). Stable isotope values from groundwater in the area around the Old Yuma Mine plot to the right of (below) both the GMWL and LMWL (fig. 5). Stable isotope values ranged from -7.1 to -8.86 per mil for $\delta^{18} \mathrm{O}$ and -51.4 to -68.5 per mil for $\delta^{2} \mathrm{H}$. The $\delta^{18} \mathrm{O}$ values are between the 10-year average value for summer (-6 per mil) and winter (-8.9 per mil), and half of the $\delta^{2} \mathrm{H}$ values are less than the 10-year average value for $\delta^{2} \mathrm{H}$ in summer (-42 per mil) and winter (-59 per mil) precipitation for Tucson. This result suggests groundwater in this area is a mix of precipitation recharged during both seasons.

Sulfate precipitation occurs in rain and as dry fallout. Reported sulfur isotopes $\left(\delta^{34} \mathrm{~S}\right)$ in precipitation near Tucson in 1996 and 1997 ranged from 2.1 to 8.5 per mil, with higher values reported in the summer (Kayaci, 1997). Reported sulfur isotopes values in dust ranged from 3.6 to 6.9 per mil (Eastoe and others, 2004). The sulfur isotopic ratio from groundwater in this study ranged from 3.25 to 13.96 per mil (fig. 6). Most samples fall within the range of precipitation and dust, with the exception of one sample with a higher value (13.96 per mil). The sample with high $\delta^{34} S$ was the only sample with a hydrogen sulfide smell noted during sample collection, and it also had the highest concentration of sulfate $(134 \mathrm{mg} / \mathrm{L})$. Sulfur isotope values greater than 10 per mil are often attributed to Permian marine gypsum (Eastoe and others, 2004), but may also represent waters that have undergone sulfate reduction (Canfield and Thamdrup, 1994).

Strontium isotopic ratio $\left({ }^{87} \mathrm{Sr} /{ }^{86} \mathrm{Sr}\right)$ in water can provide an indication of rock units the water may have interacted with along its flow path. Strontium isotope ratios in this study ranged from 0.70968 to 0.71168 . Well D-13-12 10DDA1 had the lowest strontium isotopic ratio (0.70968) and the lowest concentration of strontium ( $330 \mathrm{mg} / \mathrm{L}$ ) (fig. 7). That sample was also the farthest south and may represent groundwater moving along a different flow path compared with the other samples. The sample from well D-13-12 03DBA1 had the highest strontium isotopic ratio (0.71168) and the second lowest strontium concentration ( $480 \mathrm{mg} / \mathrm{L}$ ) (fig. 7). This sample is the only sample from a well completed in the basin fill. The other samples had higher strontium concentrations and a narrower range of strontium isotope ratios, varying from 0.71027 to 0.71158 (fig. 7).

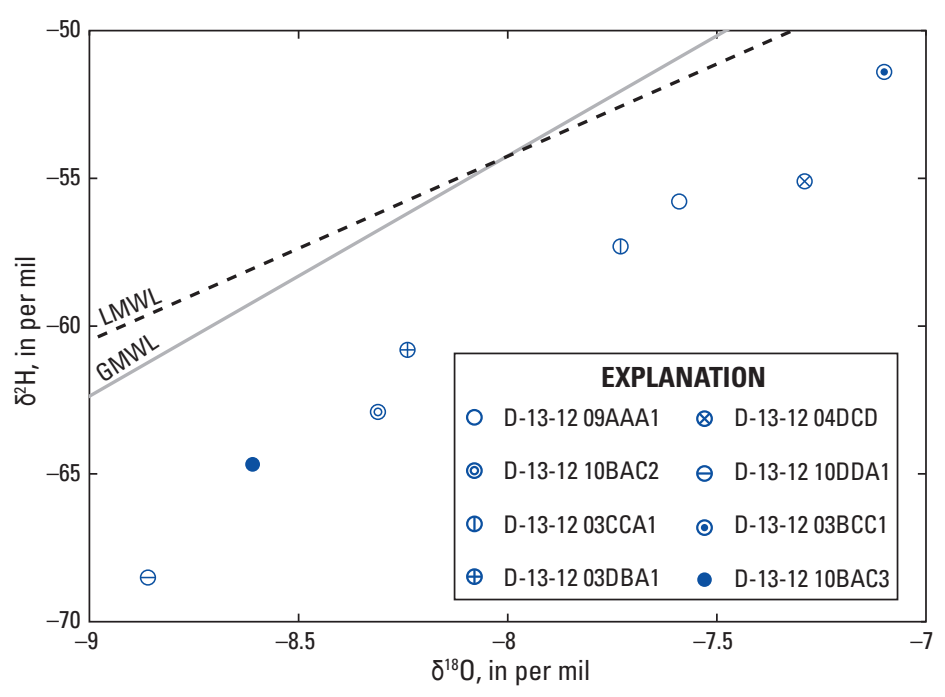

Figure 5. Stable isotope ratios $\left(\delta^{18} 0\right.$ and $\left.\delta^{2} H\right)$ for groundwater samples. Global meteoric water line (GMWL) from Craig (1961) and local meteoric water line (LMWL) from Eastoe and Dettman (2016).

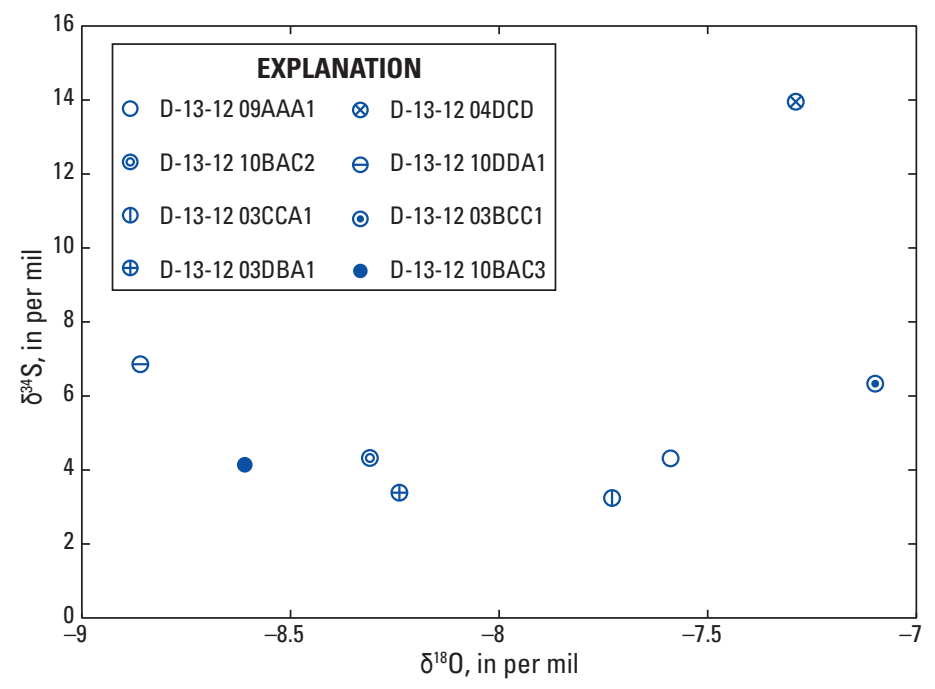

Figure 6. Stable isotope ratios $\left(\delta^{34} S\right.$ and $\left.\delta^{18} 0\right)$ for groundwater samples. 


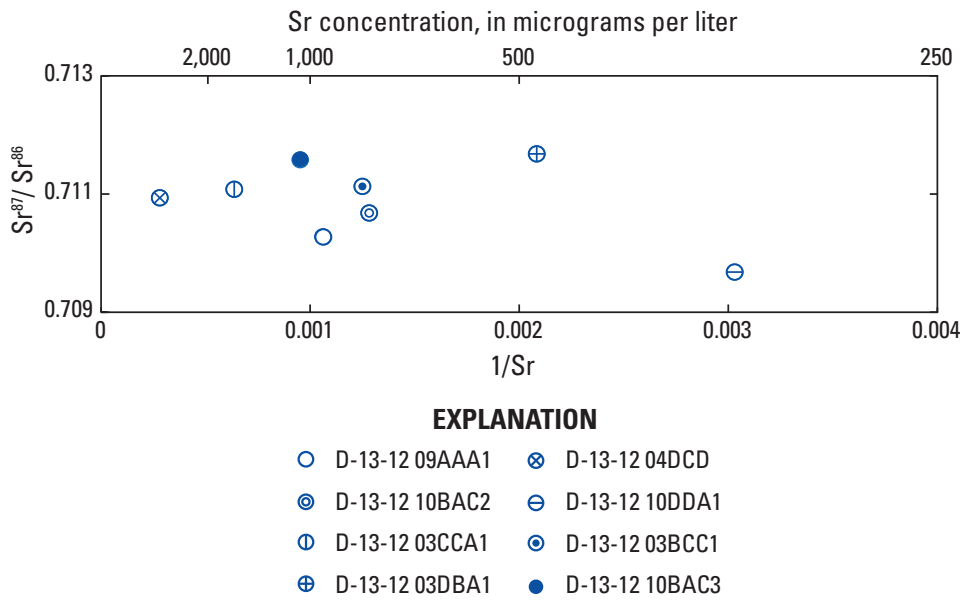

Figure 7. Strontium isotope ratio $\left({ }^{87} \mathrm{Sr} /{ }^{86} \mathrm{Sr}\right)$ versus the inverse of strontium concentration $(1 / \mathrm{Sr})$ for groundwater samples.

\section{Groundwater Age}

Groundwater age is inferred from ${ }^{14} \mathrm{C}$ with corrections based on total dissolved inorganic carbon (the sum of inorganic carbon species carbonic acid, bicarbonate, and carbonate) and $\delta^{13} \mathrm{C}$. Graphs of carbon species were made to understand the potential processes influencing carbon water chemistry at groundwater sample sites before interpretation of groundwater age, similar to Han and others (2012) and Han and Plummer (2016) (fig. 8, table 14). The blue lines on figure 8 represent the "zero-age" lines, which are determined by soil gas and solid carbonate ${ }^{14} \mathrm{C}$ and $\delta^{13} \mathrm{C}$ values. Samples that plot between the zero-age lines on figure $8 \mathrm{~A}$ do not have a radiocarbon age, and may be explained by geochemical reaction with no radiocarbon decay. Samples that plot above the zero-age area are likely mixtures containing some old recharged water, and samples that plot below the zero-age area may have a radiocarbon age greater than zero, indicating the presence of old water that has undergone radiocarbon decay (Han and Plummer, 2016). Results from NetpathXL are presented in table 14 for the uncorrected age (user defined) and revised Fontes and Garnier model (solid exchange) (Han and Plummer, 2013).

Samples from several sites plot below the zero-age area, indicating they may be old waters that could have undergone ${ }^{14} \mathrm{C}$ decay (fig. 8A) (Han and others, 2012). Sites with a possible radiocarbon age are wells D-13-12 10DDA1 and D-13-12 BAC3. These two sites, as well as D-13-12 03DBA1, also indicate a possible radiocarbon age using $10 \mathrm{pmc}$ for ${ }^{14} \mathrm{C}$ in recharge-zone carbonates from Kalin (1994).

Tritium is a useful tracer for determining if there is a component of water recharged during the period of nuclear bomb testing in the 1950s and 1960s, when tritium in the atmosphere peaked and then decreased over the following decades. Tritium values have stopped decreasing in recent precipitation (after 1992), and average recent values of tritium in precipitation in Tucson are $17 \mathrm{pCi} / \mathrm{L}$ (Eastoe and others, 2012). Tritium values of samples from this study ranged from $-0.02 \mathrm{pCi} / \mathrm{L}$ (which is below the reporting limit of $0.3 \mathrm{pCi} / \mathrm{L}$ ) to $8.9 \mathrm{pCi} / \mathrm{L}$. Three groundwater samples had tritium above the reporting limit, D-13-12 09AAA1, 04DCD, and 03BCC1
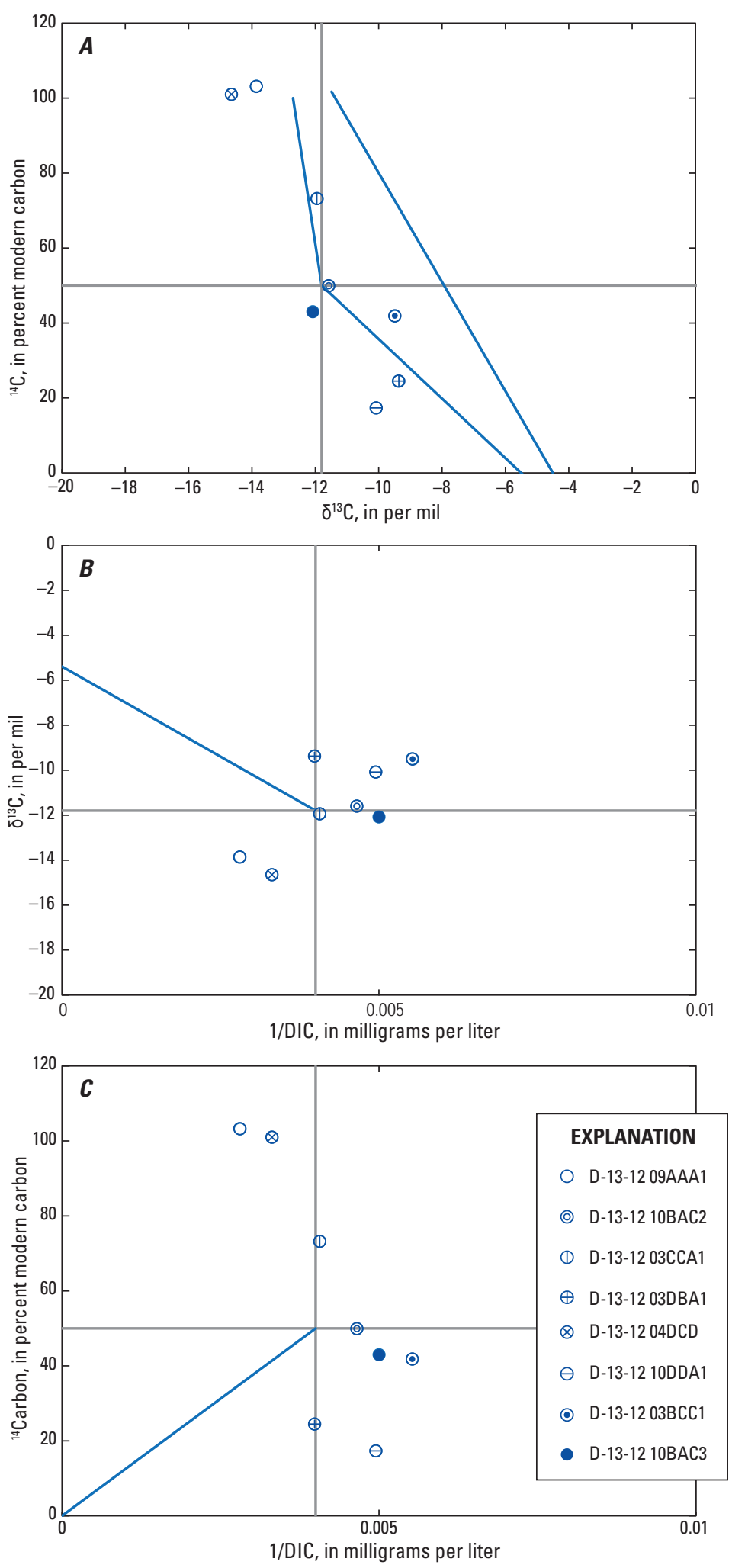

Figure 8. Graphs of carbon data from groundwater samples. $A_{1}^{14} \mathrm{C}$ versus $\delta^{13} C, B,{ }^{14} C$ versus the inverse of dissolved inorganic carbon concentration $(1 / D I C)$, and $C, \delta^{13} C$ versus $1 / D I C$. Solid gray lines represent Tamers $X$ and (or) Y (Han and Plummer, 2013). Blue lines represent zero-age lines, which are determined by soil gas and solid carbonate ${ }^{14} \mathrm{C}$ and $\delta^{13} \mathrm{C}$ values. 
(table 14). The first two of these samples had high tritium (8.9 and $5.4 \mathrm{pCi} / \mathrm{L}$, respectively) and high ${ }^{14} \mathrm{C}(103.21$ and $101.02 \mathrm{pmc}$, respectively), and plot in an area on figure 8 indicating interaction with soil $\mathrm{CO}_{2}$. The other site, D-13-12 03BCC1, had a low tritium value $(0.83 \mathrm{pCi} / \mathrm{L})$ and low ${ }^{14} \mathrm{C}(41.83 \mathrm{pmc})$, and plots within the zero-age area of figure 8 , which may indicate some equilibrium condition with respect to carbon that precludes radiocarbon age determination. The tritium data from the other five groundwater samples were below the detection limit, indicating that groundwater at these sites was primarily recharged prior to 1952 (pre-modern), and of these data, two samples (D-13-12 10BAC2 and D-13-12 03CCA1) also plot within the zero-age area of figure 8 .

Sulfur hexafluoride $\left(\mathrm{SF}_{6}\right)$ is a useful tracer for determining the presence of water recharged since the 1970s and has a high rate of increase in the atmosphere (Busenberg and Plummer,
2000). In addition to atmospheric sources, natural sources of $\mathrm{SF}_{6}$ are known to be present in rocks and minerals (Busenberg and Plummer, 2000). $\mathrm{SF}_{6}$ was analyzed in six groundwater samples from the area (table 15). Samples were not analyzed from wells B-13-12 10BAC2 and B-13-12 10BAC3 because they did not contain detectable tritium. In addition, well B-13-12 10BAC3 was drilled using air rotary less than a year before the sample was collected; the air rotary drilling method is known to affect gas concentrations in water samples for several years following drilling (Busenberg and Plummer, 2010).

To determine the influence of excess air on $\mathrm{SF}_{6}$, nitrogen and argon gas were measured in groundwater samples to determine the recharge temperature and presence of excess air, which can dissolve in groundwater during recharge and water-table fluctuations. Only one well, D-13-12 04DCD, had excess nitrogen gas $\left(\mathrm{N}_{2}\right)$, measured at $3 \mathrm{mg} / \mathrm{L}$. This well had

Table 14. Corrected radiocarbon ages for groundwater.

[pCi/L, picocuries per liter; pmc, percent modern carbon (denormalized); pM, absolute percent modern carbon (normalized); BP, before present; $\mathrm{R}$, radiochemistry non-detect; NA, not applicable]

\begin{tabular}{|c|c|c|c|c|c|c|c|c|}
\hline Site name & Sample date & $\begin{array}{c}{ }^{3} \mathrm{H}, \\
\text { in } \mathrm{pC} / \mathrm{L}\end{array}$ & $\begin{array}{c}{ }^{14} \mathrm{C}, \\
\text { in pmc }\end{array}$ & $\begin{array}{c}{ }^{14} \mathrm{C}, \\
\text { in } \mathrm{pM}\end{array}$ & $\begin{array}{c}{ }^{14} \mathrm{C} \text { error, } \\
\text { in } \mathrm{pM}\end{array}$ & $\begin{array}{l}\delta^{13} \mathrm{C} \text {, in } \\
\text { per mil }\end{array}$ & $\begin{array}{c}\text { Minimum } \\
\text { corrected age, } \\
\text { in years } \mathrm{BPa}\end{array}$ & $\begin{array}{c}\text { Maximum } \\
\text { corrected age, } \\
\text { in years } \mathrm{BP}^{\mathrm{b}}\end{array}$ \\
\hline D-13-12 10BAC2 & $1 / 11 / 2016$ & R 0.20 & 49.92 & 48.96 & 0.13 & -11.59 & NA & NA \\
\hline D-13-12 03CCA1 & $1 / 21 / 2016$ & R 0.03 & 73.20 & 71.85 & 0.23 & -11.94 & NA & NA \\
\hline D-13-12 04DCD & 2/8/2016 & 5.4 & 101.02 & 99.7 & 0.29 & -14.65 & NA & NA \\
\hline D-13-12 10DDA1 & 2/9/2016 & R 0.08 & 17.34 & 16.96 & 0.09 & -10.08 & 5,148 & 6,708 \\
\hline D-13-12 03BCC1 & 2/29/2016 & 0.83 & 41.83 & 40.86 & 0.18 & -9.49 & NA & NA \\
\hline D-13-12 10BAC3 & 8/16/2016 & $\mathrm{R}-0.02$ & 43.01 & 42.23 & 0.12 & -12.08 & 619 & 1,520 \\
\hline
\end{tabular}

${ }^{\mathrm{a}}$ Calculated assuming 0 pmc for ${ }^{14} \mathrm{C}$ in carbonate.

${ }^{\mathrm{b} C}$ Calculated assuming $10 \mathrm{pmc}$ for ${ }^{14} \mathrm{C}$ in carbonate.

Table 15. Dissolved gas values in groundwater samples.

$\left[{ }^{\circ} \mathrm{C}\right.$, degrees Celsius; $\mathrm{cm}^{3} / \mathrm{L}$, cubic centimeter per liter; STP, standard temperature and pressure; $\mathrm{mg} / \mathrm{L}$, milligrams per liter; fmol $/ \mathrm{kg}$, femtomoles per kilogram; one mole is equal to $10^{15}$ femtomoles; NA, not applicable]

\begin{tabular}{|c|c|c|c|c|c|c|}
\hline Site name & Date & $\begin{array}{l}\text { Recharge } \\
\text { temperature, } \\
\text { in }{ }^{\circ} \mathrm{C}\end{array}$ & $\begin{array}{l}\text { Excess air, in } \\
\mathrm{cm}^{3} / \mathrm{L} \text { at STP }\end{array}$ & $\begin{array}{c}\text { Excess } \mathbf{N}_{2^{\prime}} \\
\text { in } \mathrm{mg} / \mathrm{L}\end{array}$ & $\begin{array}{l}\text { Bottle headspace, } \\
\qquad \text { in } \mathbf{c m}^{3}\end{array}$ & $\begin{array}{l}\mathrm{SF}_{6^{\prime}} \text { in } \\
\mathrm{fmol} / \mathrm{kg}\end{array}$ \\
\hline D-13-12 09AAA1 & $1 / 11 / 2016$ & 22.2 & 3.3 & NA & 1.10 & 0.33 \\
\hline D-13-12 10BAC2 & $1 / 11 / 2016$ & 19.5 & 3.1 & NA & NA & NA \\
\hline D-13-12 03CCA1 & $1 / 21 / 2016$ & 19.6 & 3.1 & NA & 2.50 & 0.89 \\
\hline D-13-12 03DBA1 & $1 / 29 / 2016$ & 20.1 & 3.1 & NA & 0.80 & 1.40 \\
\hline D-13-12 04DCD & 2/8/2016 & 23.5 & 2.5 & 3.0 & 1.30 & 0.43 \\
\hline D-13-12 10DDA1 & 2/9/2016 & 18.4 & 2.8 & NA & 2.00 & 1.81 \\
\hline D-13-12 03BCC1 & 2/29/2016 & 25.7 & 3.1 & NA & 0.90 & 0.99 \\
\hline
\end{tabular}


a hydrogen sulfide smell and may have some denitrification occurring in the well, which would explain the excess $\mathrm{N}_{2}$. Excess air values ranged from 2.5 to 3.3 cubic centimeters per liter (table 15). The calculated apparent age from $\mathrm{SF}_{6}$ will decrease by approximately 2 years per cubic centimeter of excess air per kilogram of water (U.S. Geological Survey, 2017b). An estimated recharge elevation of 3,000 ft could be used in the $\mathrm{SF}_{6}$ age calculation because the highest point in the area is Wasson Peak at 4,687 ft and the majority of water would likely recharge at lower elevations than at the peak apex.

All samples collected for $\mathrm{SF}_{6}$ had concentrations above the reporting limit. Three samples (wells D-13-12 03CCA1, DBA1, and 10DDA1) contained measureable concentrations of $\mathrm{SF}_{6}$, but tritium concentration was below the detection limit. These samples had greater concentrations of $\mathrm{SF}_{6}$ than the samples with measurable tritium. This result may indicate that there is a natural source of $\mathrm{SF}_{6}$ in the study area; $\mathrm{SF}_{6}$ has been found to be present in elevated concentrations from volcanic and igneous rocks and certain minerals (Busenberg and Plummer, 2000). Because of evidence of background contributions of $\mathrm{SF}_{6}$, no age determinations were made for this dataset.

\section{Sediment Geochemistry}

\section{Bulk Sediment}

The USGS Central Region Mineral Resources laboratory analyzed sediment samples using total and partial digestion techniques. Both methods were used to provide information about the relative mobility of trace elements associated with the sediment samples. Sediment samples represent the surface and upper few inches of the soil profile.

\section{Total Digestion}

Sediment samples were analyzed by total digestion methods (Beisner, 2017; table 1). For the total digestion samples, many elements (As, Bi, Cd, Co, Cu, Fe, Hg, In, Li, Mn, Mo, Pb, Sb, $\mathrm{U}, \mathrm{V}, \mathrm{W}$, and Zn) were elevated in the waste rock and tailings compared with background sediments; some of these elements (Ag, $\mathrm{As}, \mathrm{Cu}, \mathrm{Mn}, \mathrm{Pb}, \mathrm{Zn}$ ) also were elevated in the stream sediments near the waste rock pile (fig. 9). The concentrations of lead were greatest in the waste rock samples, in stream sediment near the waste rock pile, and in background samples near the Old Yuma Fault (figs. 9, 10, 11). Moving away from the waste rock at the Old Yuma Mine, sediments show a decrease in trace element concentration with distance (fig. 11).

Four elements (As, Mo, Pb, and V) had sample concentrations greater than the EPA regional soil screening levels and (or) the AZDEQ soil screening levels (table 3). For arsenic, all sediment samples were greater than the EPA carcinogenic target risk of 3 milligrams per kilogram (mg/kg), all but one background sample (OYM-32-B) were greater than the AZDEQ soil screening level of 10 milligram per kilogram $(\mathrm{mg} / \mathrm{kg})$, and five waste rock samples (OYM-13, 14, 15, 18, and 19-W) were greater than the EPA non-cancer soil screening level of $480 \mathrm{mg} / \mathrm{kg}$. For molybdenum, two waste rock samples (OYM-14 and 15-W) were greater than the EPA soil screening level of 5,800 mg/kg and the AZDEQ soil screening level of $5,100 \mathrm{mg} / \mathrm{kg}$. For lead, all tailings, waste rock, stream sediments, and two of the background samples (OYM-26 and 36-B) were greater than the EPA and AZDEQ soil screening level of $800 \mathrm{mg} / \mathrm{kg}$. For vanadium, five waste rocks samples (OYM-12, 13, 17, 18, and 19-W) were greater than the AZDEQ soil screening level of $1,000 \mathrm{mg} / \mathrm{kg}$.

Sediment samples were compared with average soil concentrations from the Western United States (Smith and Huyck, 1999) to determine if some elements may be elevated in the background samples collected around the Old Yuma Mine. Often in areas of mining activity, there are naturally elevated trace-element concentrations related to the mineralizing event targeted by mining (Plumlee and Nash, 1996; Church and others, 2007). The background samples were collected to the south of the Old Yuma Mine disturbed area on both sides of the hill (figs. 10, 12). Generally, concentrations of elements in background samples were greatest near the Old Yuma Fault and decreased with distance to the east (fig. 12).

Many elements (Al, Fe, K, Ti, Sb, As, Ba, Be, Cd, Ce, Cs, Co, La, Pb, Li, Mn, Mo, Nb, P, Rb, Sr, Sn, and Zn) had higher values in all background samples near the Old Yuma Mine compared to average soils in the Western United States. Lead concentrations in background samples ranged from 30 to 6,410 parts per million (ppm) with a median value of $219 \mathrm{ppm}$ (table 16, fig. 9D). The average value of lead in soils from the Western United States is $17 \mathrm{ppm}$. Manganese concentrations were greater in background samples (807-7,280 ppm, median 2,510 ppm; fig. 9C) compared to the average Western United States soil value of $380 \mathrm{ppm}$. Zinc concentrations also were greater in background samples $(88-2,940 \mathrm{ppm}$, median 246 ppm; fig. 9F) compared to the average Western United States soil value of $55 \mathrm{ppm}$. These results suggest that some trace element concentrations may be naturally elevated in the sediments associated with the mineralizing event that deposited the ore at the Old Yuma Mine.

\section{Partial Digestion}

Sediment samples also were analyzed by the EPA 3050 partial digestion method (Beisner, 2017; table 2). The partial digestion results represent a less aggressive digestion, which identifies constituents that may be more available compared with total digestion results. The concentrations of $\mathrm{Al}, \mathrm{K}, \mathrm{Na}$, $\mathrm{Ti}, \mathrm{Ba}$, and $\mathrm{Sr}$ were lower in the partial digestion samples than in the total digestion samples. The concentrations of $\mathrm{Ca}, \mathrm{Fe}$, and Co also were lower in the partial digestion samples than in the total digestion samples, with a few exceptions. The concentrations of $\mathrm{Cu}$ and $\mathrm{Mn}$, as well as As and $\mathrm{Cd}$ (with a few exceptions), were greater in the partial digestion samples than in the total digestion samples. 

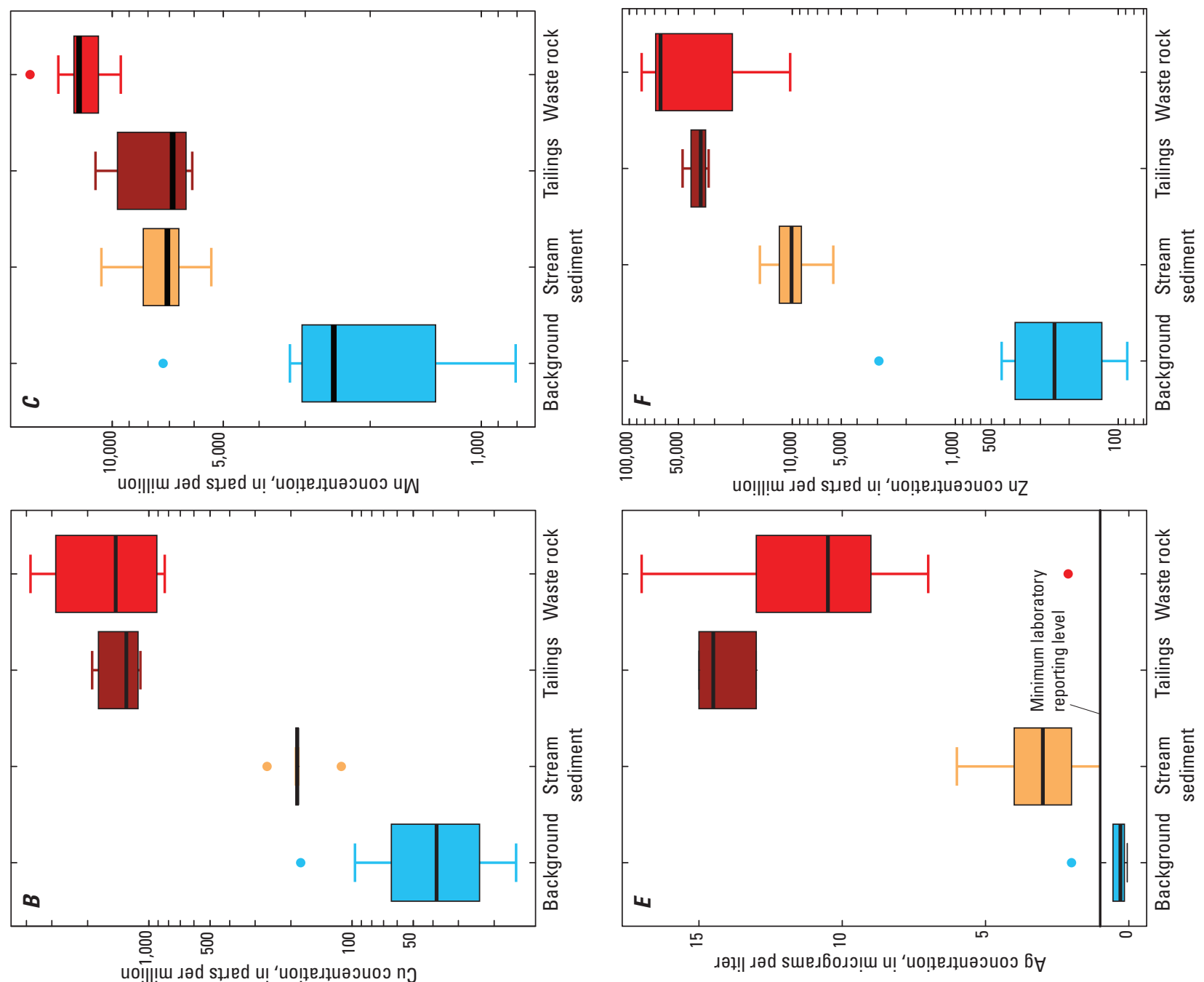

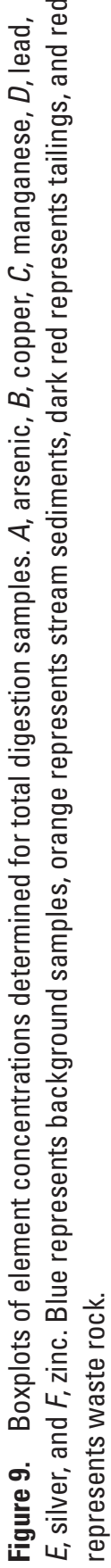
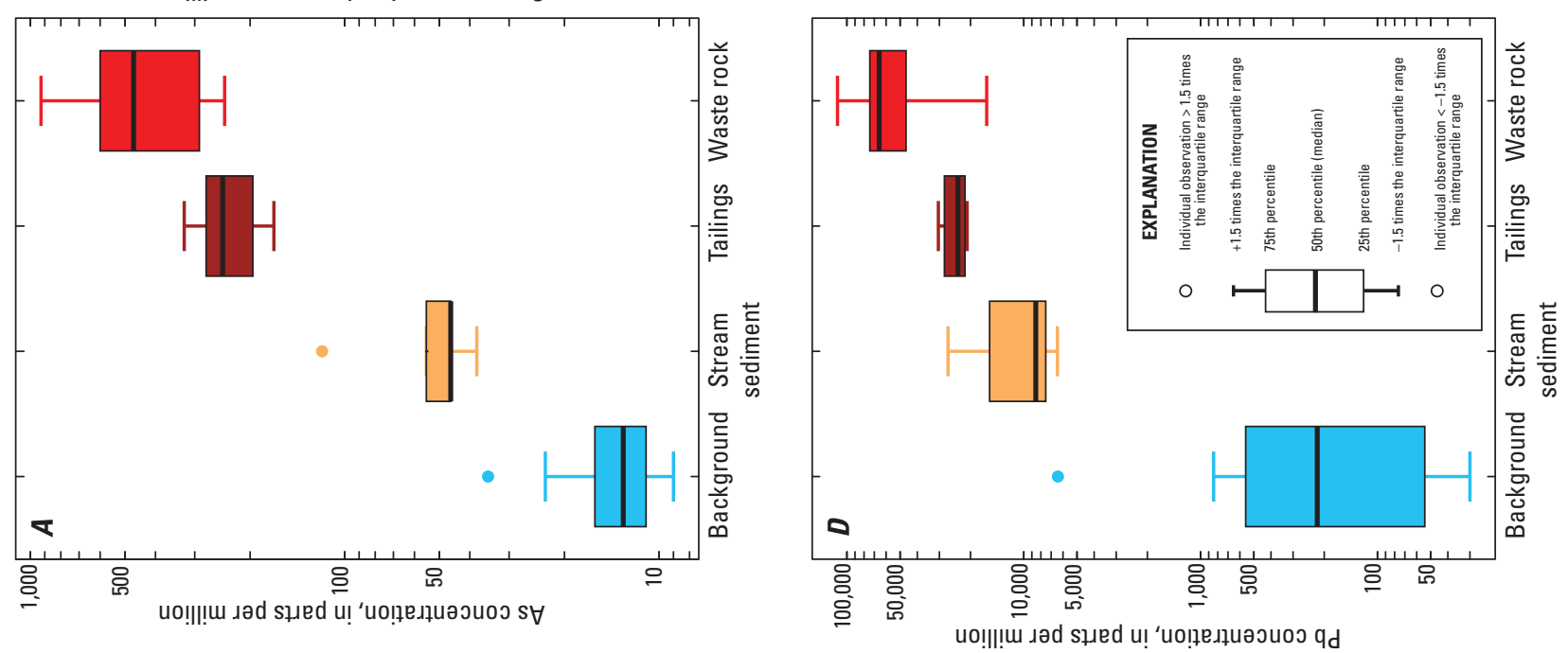

. 

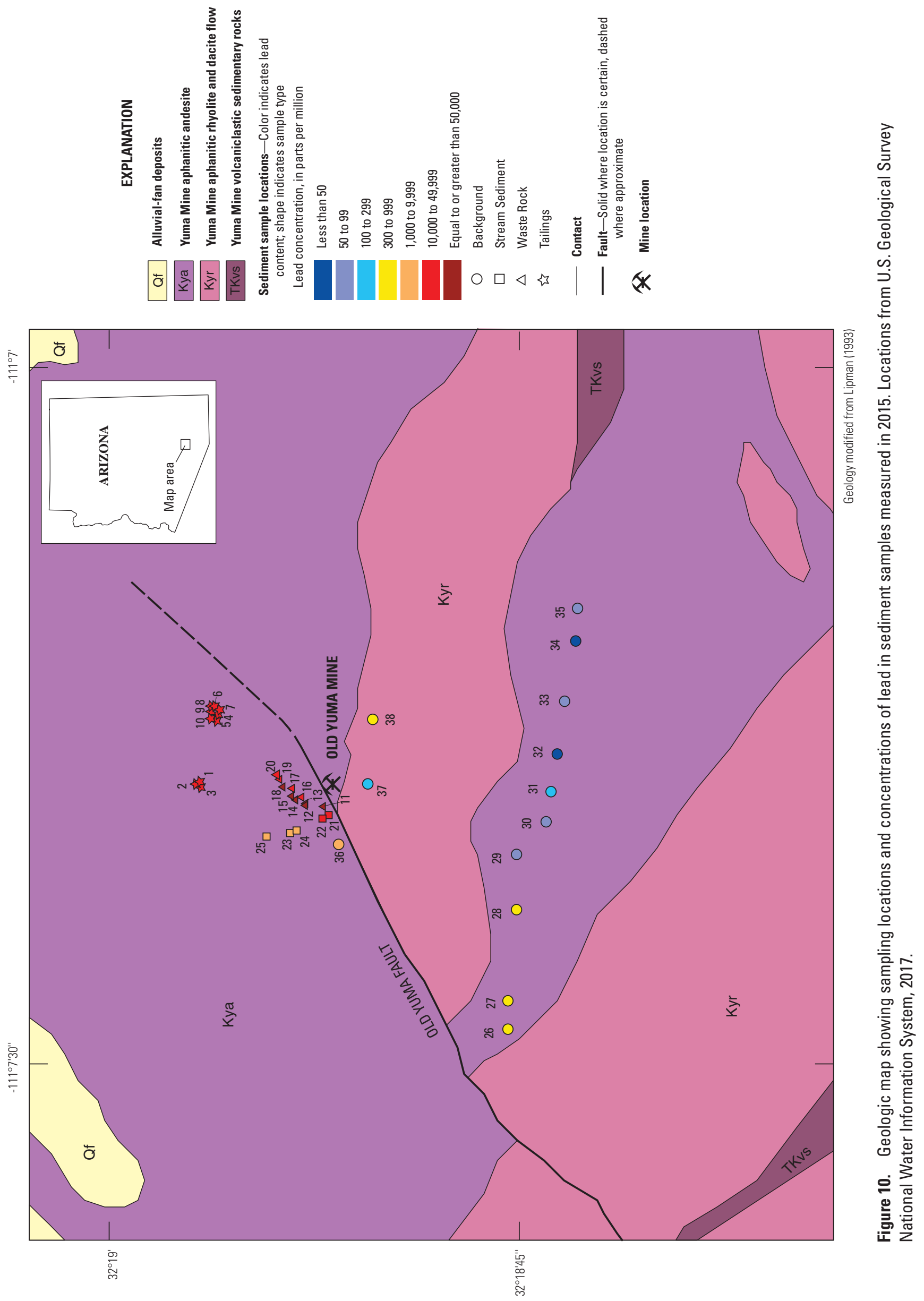


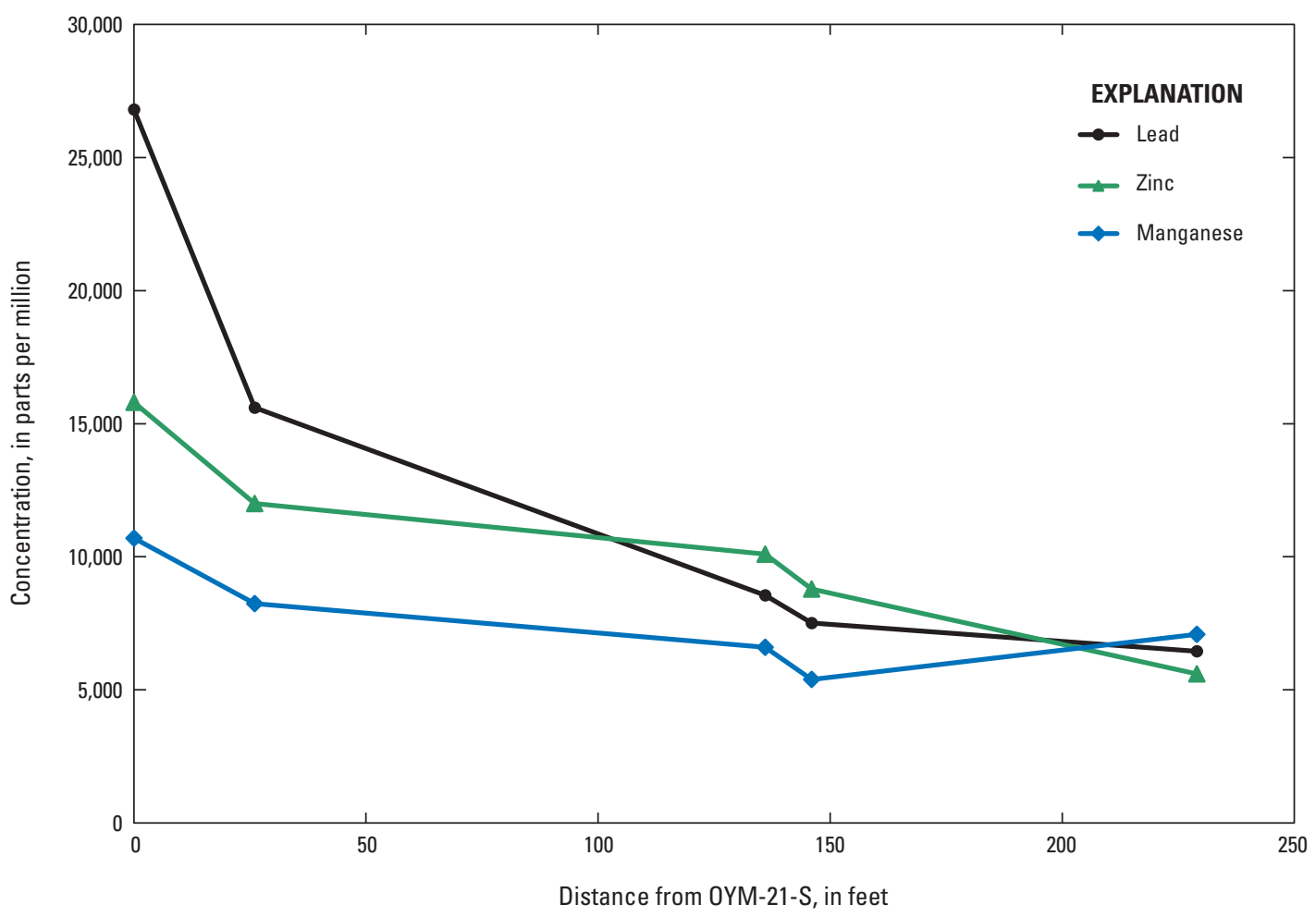

Figure 11. Graph of lead, zinc, and manganese concentrations in stream sediment samples with increasing downgradient distance from sample site OYM-21-S.

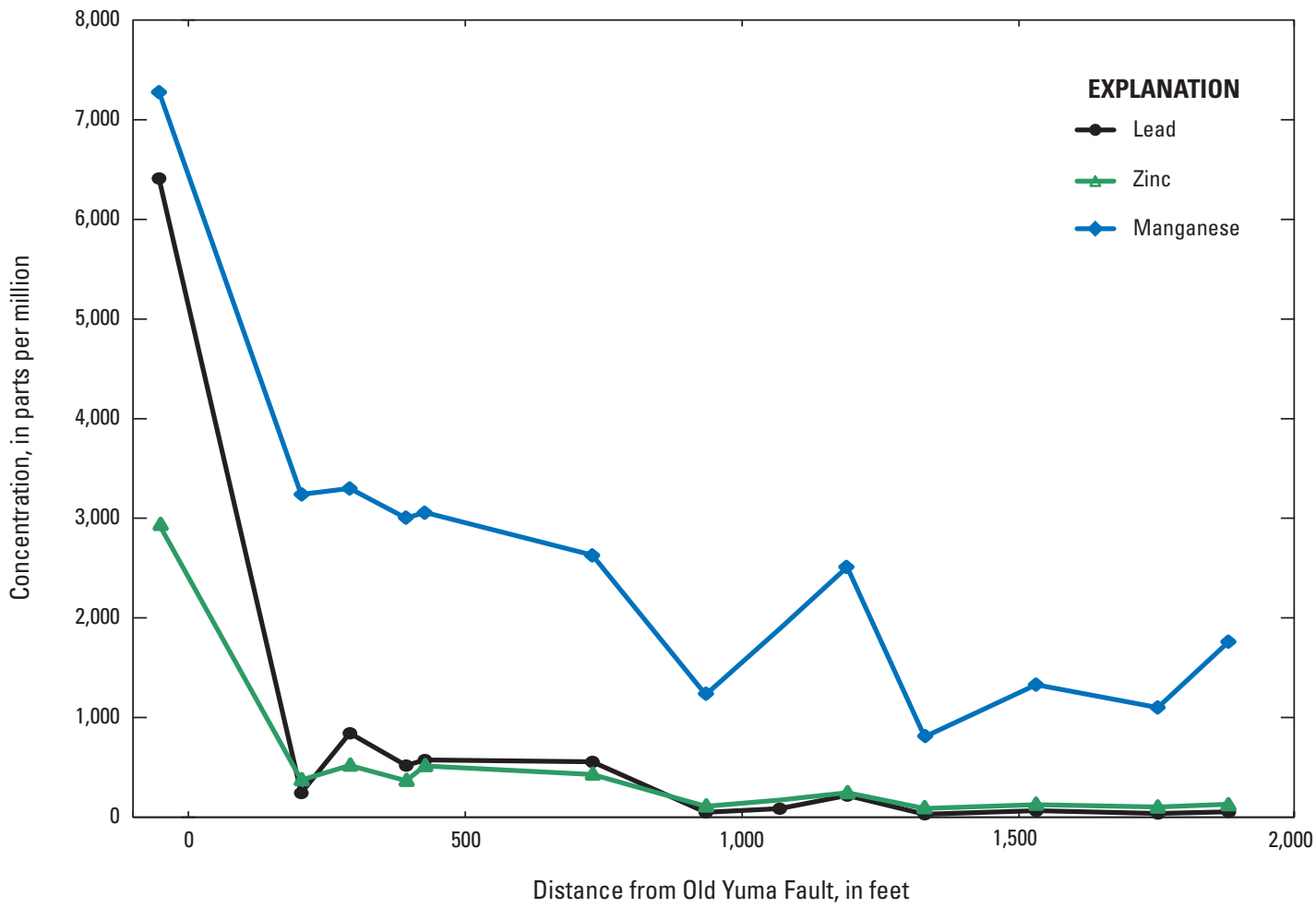

Figure 12. Graph of lead, zinc, and manganese concentrations in background sediment samples versus distance from the Old Yuma Fault. 
Table 16. Concentrations of elements from background sediments near the Old Yuma Mine compared with average values from the Western United States.

[Bold values indicate background samples greater than mean of Western United States values; \%, percent; ppm, parts per million]

\begin{tabular}{|c|c|c|c|}
\hline Element & Units & $\begin{array}{l}\text { Mean concentration from } \\
\text { Western United States soils }\end{array}$ & $\begin{array}{l}\text { Concentration range of } \\
\text { background samples near } \\
\text { Old Yuma Mine }\end{array}$ \\
\hline $\mathrm{Al}$ & $\%$ & 5.8 & $6.98-8.52$ \\
\hline $\mathrm{Ca}$ & $\%$ & 1.8 & $0.73-4.78$ \\
\hline $\mathrm{C}$ & $\%$ & 1.7 & $0.67-1.64$ \\
\hline $\mathrm{Fe}$ & $\%$ & 2.1 & $3.08-4.56$ \\
\hline $\mathrm{Mg}$ & $\%$ & 0.74 & $0.38-1.51$ \\
\hline $\mathrm{K}$ & $\%$ & 1.8 & $244-4.38$ \\
\hline $\mathrm{Na}$ & $\%$ & 0.97 & $0.84-1.89$ \\
\hline $\mathrm{S}$ & $\%$ & 0.13 & $<0.01-0.02$ \\
\hline $\mathrm{Ti}$ & $\%$ & 0.22 & $0.34-0.54$ \\
\hline $\mathrm{Sb}$ & ppm & 0.47 & $177-25.7$ \\
\hline As & ppm & 5.5 & 9-35 \\
\hline $\mathrm{Ba}$ & ppm & 580 & $759-1,230$ \\
\hline $\mathrm{Be}$ & ppm & 0.68 & $14-2.2$ \\
\hline $\mathrm{Cd}$ & ppm & 0.06 & $0.2-5.5$ \\
\hline $\mathrm{Ce}$ & ppm & 65 & $69.5-88.7$ \\
\hline Cs & ppm & 6 & $10-39$ \\
\hline $\mathrm{Cr}$ & ppm & 41 & $14-71$ \\
\hline Co & ppm & 7.1 & $10.5-22.3$ \\
\hline $\mathrm{Cu}$ & ppm & 21 & $15.6-179$ \\
\hline $\mathrm{Ga}$ & ppm & 16 & $16-20.4$ \\
\hline $\mathrm{La}$ & ppm & 30 & $31.1-43.1$ \\
\hline $\mathrm{Pb}$ & ppm & 17 & $30-6,410$ \\
\hline $\mathrm{Li}$ & ppm & 22 & $76-152$ \\
\hline $\mathrm{Mn}$ & ppm & 380 & $807-7,280$ \\
\hline $\mathrm{Hg}$ & ppm & 0.046 & $0.02-0.06$ \\
\hline Mo & ppm & 0.85 & $0.99-29.4$ \\
\hline $\mathrm{Ni}$ & ppm & 15 & $10-44.6$ \\
\hline $\mathrm{Nb}$ & ppm & 8.7 & 9-15.6 \\
\hline $\mathrm{P}$ & ppm & 320 & $570-1,030$ \\
\hline $\mathrm{Rb}$ & ppm & 69 & 124-266 \\
\hline Sc & ppm & 8.2 & $8.2-13.9$ \\
\hline $\mathrm{Ag}$ & ppm & 0.05 & $<1-2$ \\
\hline $\mathrm{Sr}$ & ppm & 200 & $213-414$ \\
\hline Th & ppm & 9.1 & $6.5-11.9$ \\
\hline Sn & ppm & 0.9 & 1.7-94.7 \\
\hline $\mathrm{U}$ & ppm & 2.5 & $1.8-3.2$ \\
\hline $\mathrm{V}$ & ppm & 70 & $67-186$ \\
\hline $\mathrm{Y}$ & ppm & 22 & $18.5-24.1$ \\
\hline $\mathrm{Zn}$ & ppm & 55 & $88-2,940$ \\
\hline
\end{tabular}

\footnotetext{
${ }^{1}$ Average soil data from the Western United States from Smith and Huyck (1999) reported as ppm and converted for some elements in
} this table. 


\section{Sediment Leachate}

A subset of 15 sediment samples were leached in accordance with the EPA 1312 leachate method to simulate precipitation interacting with the solid material (Beisner, 2017; table 3). The concentrations of leachate samples, however, do not reflect dilution that leachate waters would undergo in the surrounding environment. The dilution factor would depend on the flow rate and water volume, which was not determined in this study.

The $\mathrm{pH}$ of the leachate samples increased following the leaching procedure. The initial $\mathrm{pH}$ was lowest for tailings samples (6.53-7.33) and variable for other samples (7.18-9.19), whereas the final $\mathrm{pH}$ values following the leachate procedure were generally alkaline (8.67-9.72), indicating that the mine waste has low acid-generating potential.

Several leachate samples exceeded the EPA drinking water standards for arsenic, manganese, and lead. Exceedances occurred for all leachates of tailings and waste rock sediment samples, as well as stream sediments collected in a small drainage near the mine. Some leachates of background samples collected south of the mine had concentrations that exceeded the EPA drinking water standard for lead (OYM-28 and 37-B) and the EPA secondary drinking water standard for manganese (OYM-27-B, 28, and 37-B).

\section{Discussion}

\section{Assessment of Groundwater Compared with Sediment and Associated Leachate}

Geochemical comparisons can be made between the chemistry of the sediment associated with mining activities compared with sediment of similar geologic origin that has not been mined to understand better what elements are associated with the mining activity. The associated sediment leachate can be compared with the groundwater chemistry to understand if there is a component of the groundwater derived from fluids in contact with mining material. Both of these comparisons provide valuable geochemical fingerprints for mining-related signatures that can be used to assess impacts to the current system and for comparison with future samples.

A NMDS analysis was conducted on the total digestion sediment data to understand dissimilarity between sediment samples and what constituents may be responsible for the dissimilarity. The NMDS analysis of the sediment data resulted in two convergent solutions after 20 tries with a stress of 0.064 (fig. 13), which implies a fair to good fit (Buttigieg and Ramette, 2014). Many constituents are associated with separation between background samples (P, Sc, Be, organic carbon [OC], K, Y, Ti, Nb, Al, Th, La, Ce, Cs, Rb, Ba, Na, $\mathrm{Ga}$ ) compared with tailings and waste rock (W, In, Bi, Ag, Fe, $\mathrm{Cu}, \mathrm{Zn}, \mathrm{Sb}, \mathrm{Co}, \mathrm{As}, \mathrm{Li}, \mathrm{Mo}, \mathrm{Pb}, \mathrm{U}, \mathrm{Hg}, \mathrm{Mn}, \mathrm{Cd}, \mathrm{V})$ on the first NMDS axis [NMDS1]. Separation between the tailings (Fe, $\mathrm{Ag}, \mathrm{In}, \mathrm{Bi}, \mathrm{W}$ ) and waste rock (Cd, V, Mn, Hg, U, Pb, Mo, As, Li) occurs on the second NMDS axis [NMDS2]. The stream sediment samples plot between the tailings, waste rock, and background samples indicating that the stream sediment may have a component of mining-related material (fig. 13).

A similarity analysis (ANOSIM) on the sediment samples relative to the sediment-type group resulted in a test statistic of 0.8559 and a p-value of 0.001 , indicating there is a statistical difference between at least two of the groups. A cluster analysis was also run on the same elements used in the NMDS analysis and is shown in figure 14. The Calinski criterion indicates that there are two distinct groups: one group includes all tailings samples and all but one waste rock sample and the other group includes waste rock sample OYM-20-W plus all stream sediment and background samples (fig. 14). The separation of the sediment samples generally indicates the mining-related material is distinct from the stream sediment and background samples.

Leachate samples were compared with groundwater samples using a NMDS analysis. The multivariate results show similar distribution when the analysis used major and trace elements compared with trace elements only; thus, only the trace element analyses are presented here. The NMDS analysis of the leachate data resulted in two convergent solutions after 20 tries with a stress of 0.094 (fig. 15), indicating a fair to good fit (Buttigieg and Ramette, 2014). Several elements were associated with separation between leachate from tailings, waste rock, and stream sediment samples (Ag, As, $\mathrm{Cd}, \mathrm{Cr}, \mathrm{Cu}, \mathrm{Mo}, \mathrm{Pb}, \mathrm{Sb}, \mathrm{Zn}$ ) compared with groundwater samples (Ba, Se, Sr, U, V) on the first NMDS axis [NMDS1] (fig. 15). Leachates from background sediment samples plotted between the groundwater and mining-related material leachates on the first NMDS axis and separated on the second NMDS axis [NMDS2] based on aluminum (fig. 15). Based on these analyses the groundwater samples do not seem to have been influenced by leachate from mining material at the Old Yuma Mine. 


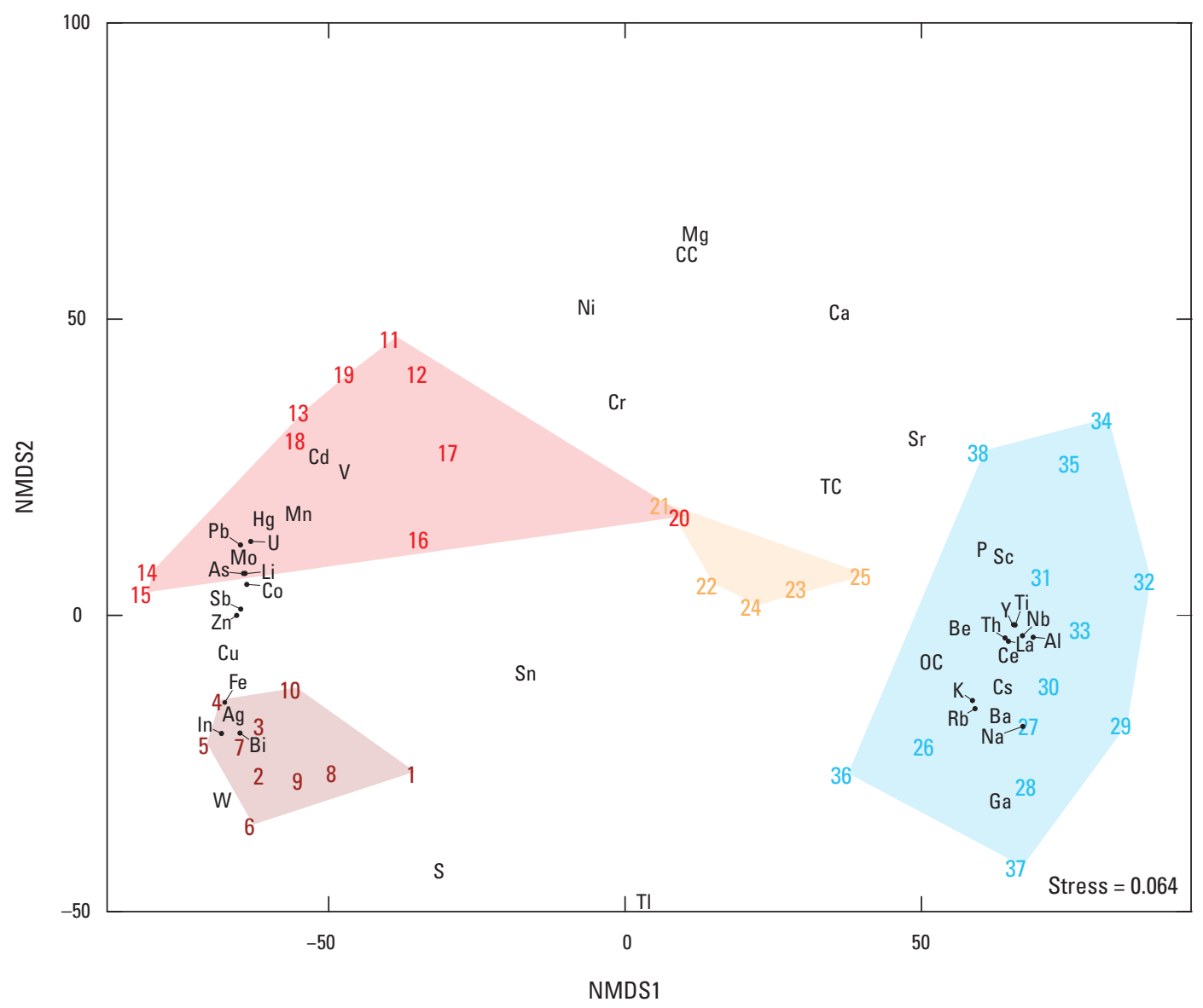

Figure 13. Non-metric multidimensional scaling (NMDS) plot for sediment samples with shaded areas outlining sediment sample type. Blue numbers and colored areas represent background samples, orange represents stream sediment, red represents waste rock, and dark red represents tailings. Numbers refer to the sediment sample sequence number. CC, carbonate carbon, $\mathrm{OC}$, organic carbon, $\mathrm{TC}$, total carbon. 


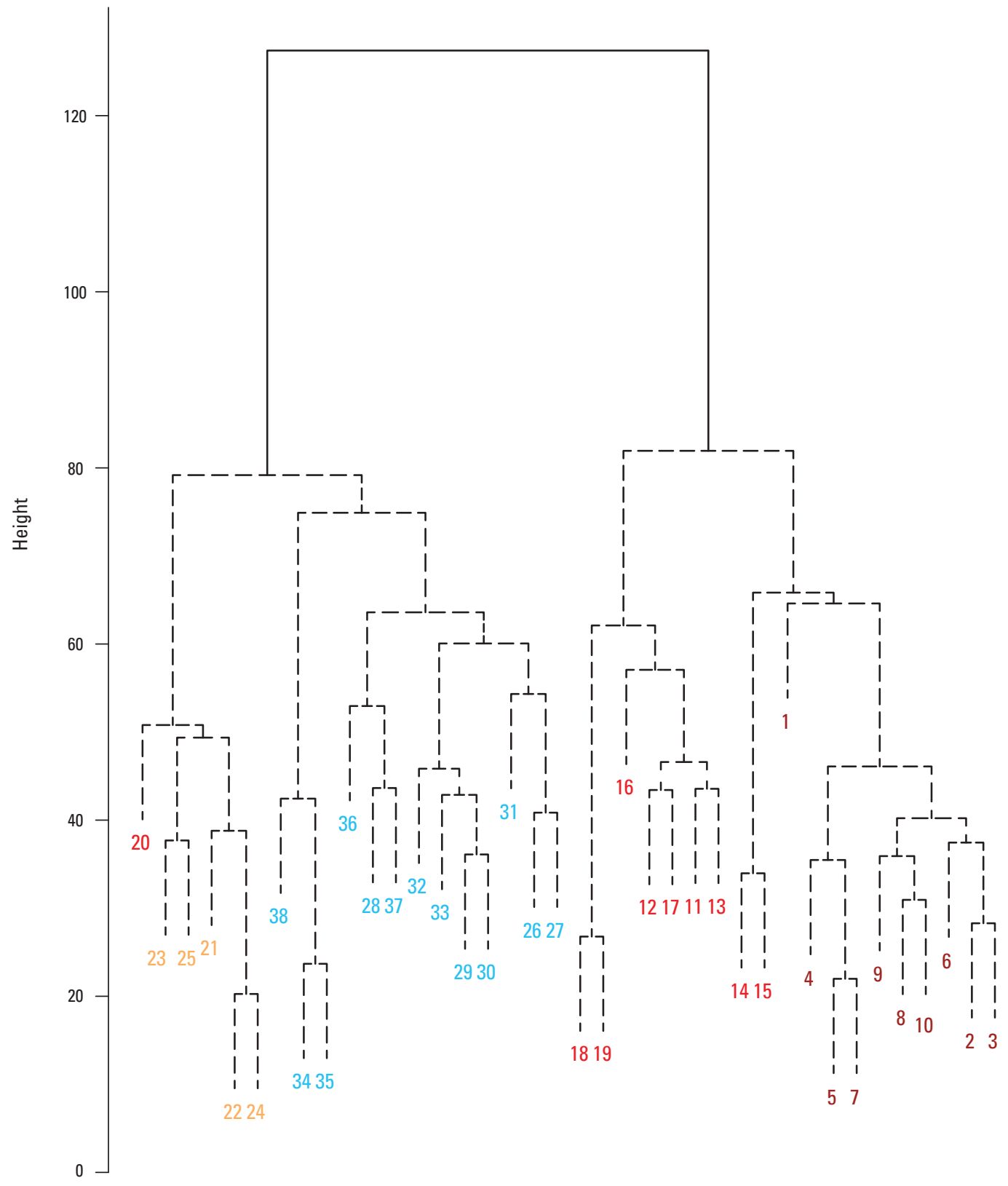

Figure 14. Cluster dendrogram for sediment samples. Numbers refer to the sediment sample sequence number. Blue numbers represent background samples, orange represents stream sediment, red represents waste rock, and dark red represents tailings. Solid lines represent distinct groups as determined by the Calinski criterion and dashed lines show subdivisions considered indistinct. 


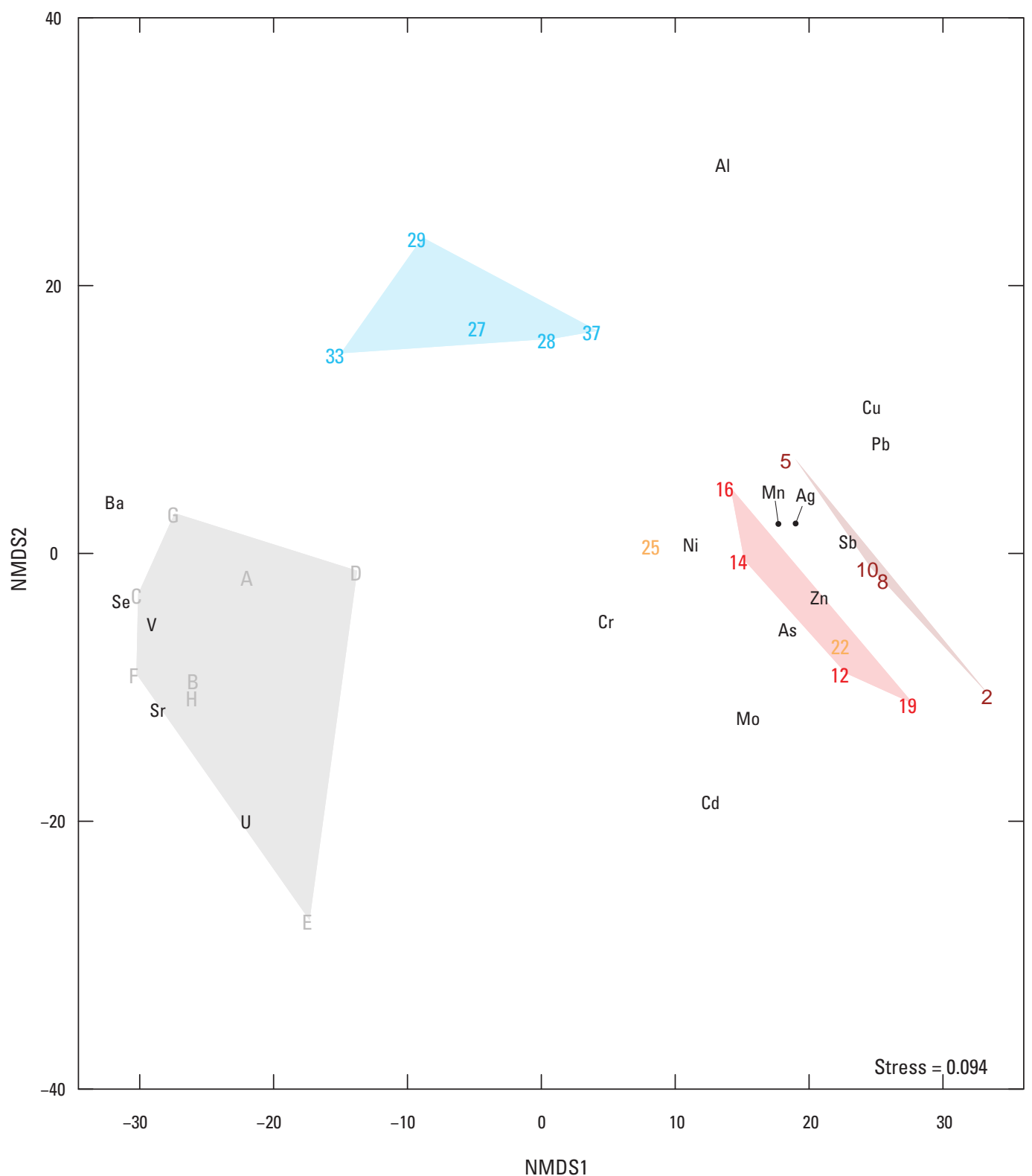

Figure 15. Non-metric multidimensional scaling (NMDS) plot for leachate and groundwater samples with shaded areas outlining aqueous sample type. Numbers represent the sediment sample sequence number. Letters refer to groundwater samples: A) D-13-12 09AAA1, B) D-13-12 10BAC2, C) D-13-12 03CCA1, D) D-13-12 03DBA1, E) D-13-12 04DCD, F) D-13-12 10DDA1, G) D-13-12 $03 \mathrm{BCC}$, and H) D-13-12 10BAC3. Blue numbers and colored area represents background samples, orange represents stream sediment, red represents waste rock, dark red represents tailings, and gray represents groundwater. 
An ANOSIM analysis on the sediment samples relative to the type of sample resulted in a test statistic of 0.761 and a p-value of 0.001 , indicating there is a statistical difference between at least two of the groups. A cluster analysis was also run on the same elements used in the NMDS analysis and is presented in figure 16. The Calinski criterion indicates that there are two statistically distinct groups. One group includes all mining-related-material and stream sediment leachates, and the other includes background and groundwater samples (fig. 16). The separation of the samples into two groups indicates the samples associated with mining material and stream sediment are distinct from the samples associated with background as well as the groundwater samples.
Strontium isotope ratio was measured on seven leachate samples. Leachate from tailings, waste rock, and stream sediment samples had higher values of strontium isotope ratios (0.71170-0.71228) compared with leachate from the background sediment samples (0.71060-0.71107) (fig. 17). More sample analyses would be needed to determine if the difference is statistically significant. The groundwater sample strontium isotope ratios $(0.70968-0.71168)$ were less than the ratios for mining-related material and similar to background leachate values. The length of time the leachates were exposed to water was shorter than the travel time of groundwater through the subsurface, so the direct comparison of leachate and groundwater samples cannot be made, but can be made generally.

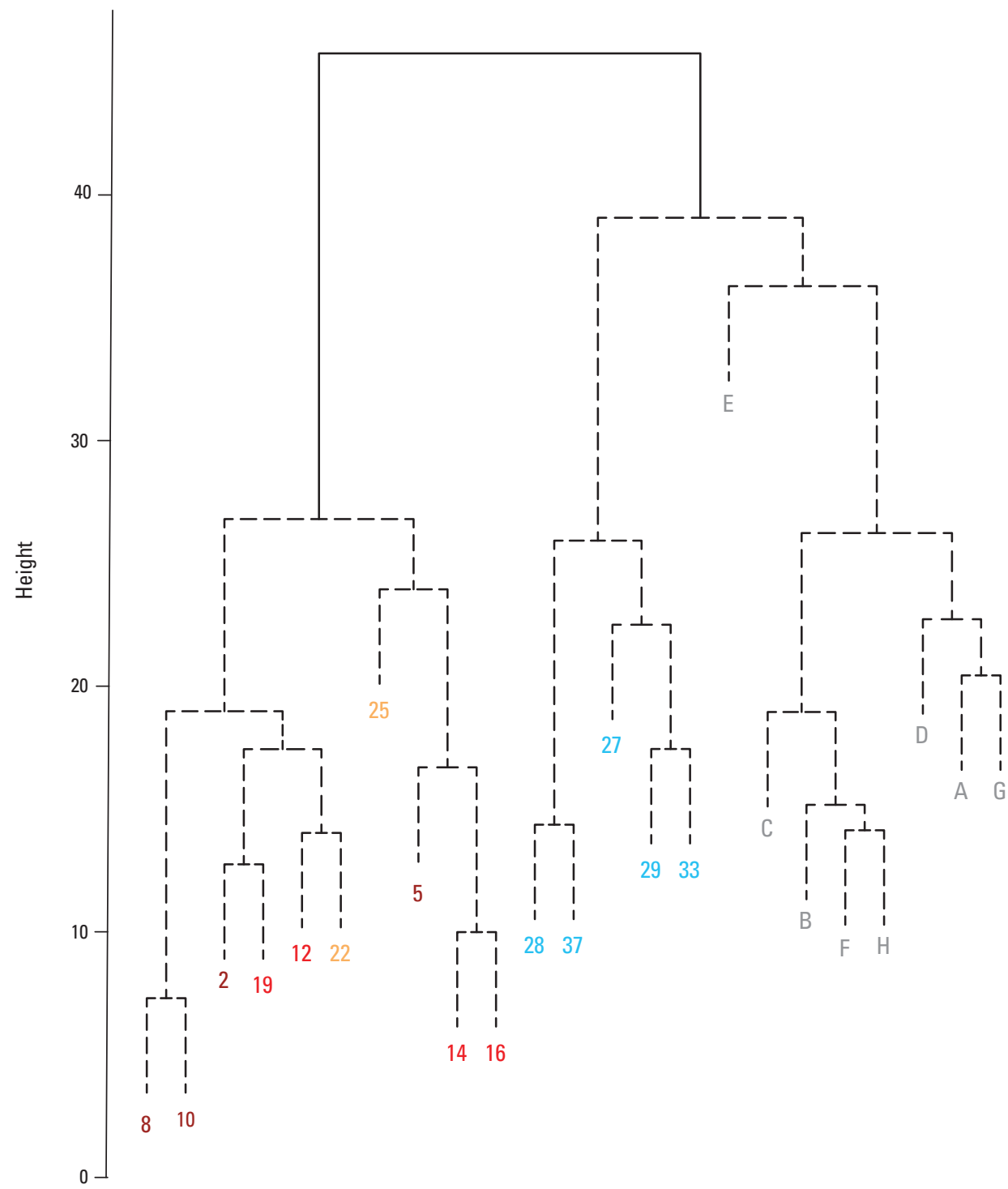

Figure 16. Cluster dendrogram for leachate and groundwater samples. Numbers represent the sediment sample sequence number. Letters refer to groundwater samples: A) D-13-12 09AAA1, B) D-13-12 10BAC2, C) D-13-12 03CCA1, D) D-13-12 03DBA1, E) D-13-12 04DCD, F) D-13-12 10DDA1, G) D-13-12 03BCC1, and H) D-13-12 10BAC3. Blue numbers and colored area represents background samples, orange represents stream sediment, red represents waste rock, and dark red represents tailings. Solid lines represent distinct groups as determined by the Calinski criterion and dashed lines show subdivisions considered indistinct. 


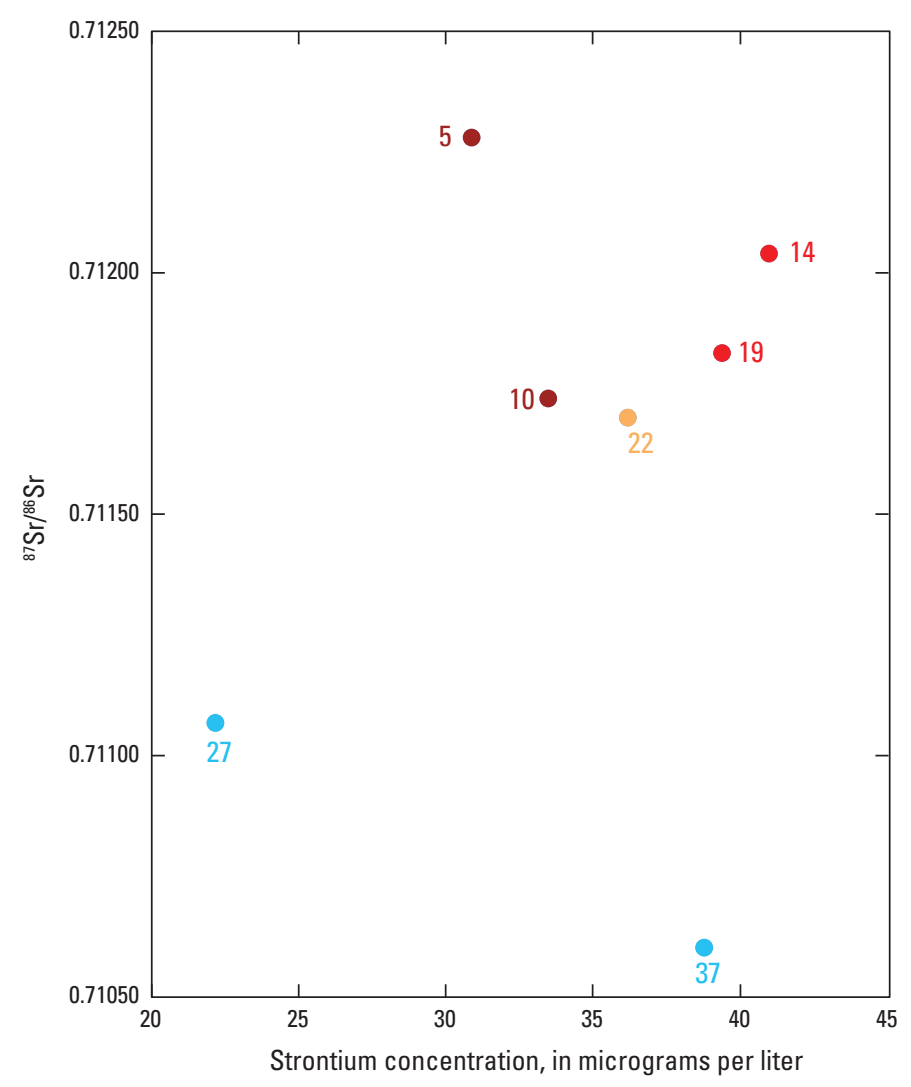

Figure 17. Strontium isotopic value versus strontium concentration for leachate samples. Numbers refer to the sediment sample sequence number. Blue represents background samples, orange represents stream sediment, red represents waste rock, and dark red represents tailings.

\section{Conclusions}

On the basis of observed water levels, groundwater is generally moving toward the northeast in the Old Yuma Mine study area. Additionally, there is a locally anomalous steep gradient in the groundwater elevation beneath the Quaternary alluvial fan deposits in the center of the study area near the projected trend of the Old Yuma Fault. Groundwater levels within the study area varied $4.5 \mathrm{ft}$ on average over a 2-year period, with a maximum change of $22 \mathrm{ft}$ from historical water levels. Based on groundwater elevation measurements across the study area, an estimate of groundwater elevation beneath the Old Yuma Mine is between 2,400 and 2,450 ft, suggesting the water table is below the 200-ft level of the mine (which is known to be dry). More groundwater elevations near the mine are needed to refine the local groundwater elevation surface, due to the presence of local anomalies in water table elevation located near the Old Yuma fault.

Few groundwater samples exceeded the EPA drinking water standards. One sample exceeded the EPA primary drinking water standard for arsenic; one sample exceeded the EPA secondary drinking water standard for chloride, iron, and manganese and two other samples exceeded the total dissolved solids secondary drinking water standard. These results suggest the water sampled in the study area is generally of good quality with localized areas of poor quality water.

Analysis of groundwater age indicates groundwater with a component of modern water, containing tritium above the laboratory reporting level, is present on the northwest side of the study area. Groundwater on the southeast side of the study area is primarily older groundwater with tritium below the laboratory reporting level and radiocarbon age ranging from approximately 600 to 6,700 years before present.

Soil screening levels provide thresholds for comparison with human health risks from the sediment associated with the Old Yuma Mine. Comparison of exceedances of standards from background samples with mining-related samples helps to differentiate hazards related to mining-related material. The geochemistry of sediments associated with the Old Yuma Mine and nearby background samples were analyzed by total and partial digestion methods. The relative similarity of concentrations between the total and partial digestions indicate that many of the trace elements associated with mining activity may be in an easily mobilized state. For total digestion samples, four elements (As, Mo, Pb, and V) had concentrations greater than the EPA regional soil screening levels and (or) the AZDEQ soil screening levels. These elements were elevated in some of the mining-related samples; arsenic and lead were elevated in some background samples. Additionally, many elements (Al, $\mathrm{Fe}, \mathrm{K}, \mathrm{Ti}, \mathrm{Sb}, \mathrm{As}, \mathrm{Ba}, \mathrm{Be}, \mathrm{Cd}, \mathrm{Ce}, \mathrm{Cs}, \mathrm{Co}, \mathrm{La}, \mathrm{Pb}, \mathrm{Li}, \mathrm{Mn}$, Mo, Nb, P, Rb, Sr, Sn, and Zn) had higher concentrations in all background samples near the Old Yuma Mine compared to other soils in the Western United States, suggesting there may be some naturally elevated trace element concentrations in the sediments associated with the mineralizing event that deposited the ore at the Old Yuma Mine.

A NMDS analysis of the geochemistry of sediment samples indicates the sediment associated with tailings and waste rock have different geochemical signatures than background sediments. Stream sediment samples plotted between the tailings, waste rock, and background samples, indicating they have some component of both mining and background sources.

A subset of 15 sediment samples were leached following the EPA 1312 leachate method to simulate precipitation interacting with the solid material. The $\mathrm{pH}$ of the leachate samples increased following the leaching procedure, indicating that waste from the Old Yuma Mine has low acid-generating potential. Several leachate samples exceeded the EPA drinking water standards for arsenic, manganese, and lead. Exceedances occurred for all leachates of mining-related material (tailings and waste rock) as well as stream sediments collected in a small drainage near the mine. Some leachates of background samples collected south of the mine had concentrations that exceeded the EPA drinking water standard for lead and the EPA secondary drinking water standard for manganese. The leachates represent a concentrated solution in contact with mining material and would likely be subject to dilution 
as the leachate moves through the groundwater system. A NMDS analysis suggests that groundwater samples collected in this study are similar to each other and distinct from leachate samples associated with mining-related material. Thus, the groundwater samples in this study do not seem to be influenced by the elements associated with leachate from Old Yuma mining material at this time.

\section{References Cited}

Arizona Department of Environmental Quality, 2009, Supp. 09-1 of Department of Environmental Quality Remedial Action, chap. 7 of Arizona Administrative Code: Arizona Department of Environmental Quality, 40 p., accessed on June 27, 2017, at http://apps.azsos.gov/public_services/ Title_18/18-07.pdf.

Baker, M., Jr., 2005, Final preliminary assessment/site inspection report, 10 Old Yuma Mine, Saguaro National Park, Tucson, Ariz.: Report prepared for the National Park Service.

Beisner, K.R., 2017, Geochemistry of sediment and associated leachates from samples near the Old Yuma Mine, AZ: U.S. Geological Survey data release, https://doi.org/10.5066/ F7348J85.

Bullen, T.D., Krabbenhoft, D., and Kendall, C., 1996, Kinetic and mineralogic controls on the evolution of groundwater chemistry and ${ }^{87} \mathrm{Sr} /{ }^{86} \mathrm{Sr}$ in a sandy silicate aquifer, northern Wisconsin: Geochimica et Cosmochimica Acta, v. 60, no. 10, p. 1807-1821.

Busenberg, E., and Plummer, L.N., 2000, Dating young groundwater with sulfur hexafluoride - Natural and anthropogenic sources of sulfur hexafluoride: Water Resources Research, v. 36, no. 10, p. 3011-3030.

Busenberg, E., and Plummer, L.N., 2010, A rapid method for the measurement of sulfur hexafluoride $\left(\mathrm{SF}_{6}\right)$, trifluoromethyl sulfur pentafluoride $\left(\mathrm{SF}_{5} \mathrm{CF}_{3}\right)$, and Halon $1211\left(\mathrm{CF}_{2} \mathrm{ClBr}\right)$ in hydrologic tracer studies: Geochemistry, Geophysics, Geosystems, v. 11, no. 11, https://doi. org/10.1029/2010GC003312.

Buttigieg, P.L., and Ramette, A., 2014, A guide to statistical analysis in microbial ecology-A community-focused, living review of multivariate data analyses: FEMS Microbiology Ecology, v. 90, p. 543-550.

Canfield, D.E., and Thamdrup, B., 1994, The production of 34S-depleted sulfide during bacterial disproportionation of elemental sulfur: Science, v. 266, no. 5193, p. 1973-1975, https://doi.org/10.1126/science.11540246.
Chon, E., Gabriel, M., Harders, S., Hou, X., Layton, R., Okbay, M., Roth, K., Rzechula, L., Sternberg, B., Tuten, T., and Weber, A., 2016, Geophysical surveys near Old Yuma Mine, Tucson Mountains, Arizona, Laboratory for Advanced Subsurface Imaging LASI-16-1: University of Arizona Geophysics Field Camp 2016, 143 p., accessed July 13, 2016, at http://www.lasi.arizona.edu/GEN\%20416516\%202016\%20Final\%20Report.pdf.

Church, S.E., von Guerard, Paul, and Finger, S.E., eds., 2007, Integrated investigations of environmental effects of historical mining in the Animas River watershed, San Juan County, Colorado: U.S. Geological Survey Professional Paper 1651, 1,096 p.

Craig, H., 1961, Isotopic variations in meteoric waters: Science, v. 133, p. 1702-1703.

Eastoe, C.J., Watts, C.J., Ploughe, M., and Wright, W.E., 2012, Future use of tritium in mapping pre-bomb groundwater volumes: Groundwater, v. 50, no. 1, p. 87-93.

Eastoe, C.J., Gu, A., and Long, A., 2004, The origins, ages and flow paths of groundwater in Tucson Basin-Results of a study of multiple isotope systems, in Hogan, J.F., Phillips F.M., and Scanlon B.R., Groundwater recharge in a desert environment-The southwestern United States: Washington D.C., American Geophysical Union, p. 217-234, http://doi. org/10.1029/009WSA12.

Eastoe, C.J., and Dettman, D.L., 2016, Isotope amount effects in hydrologic and climate reconstructions of monsoon climates-Implications of some long-term data sets for precipitation: Chemical Geology, v. 430, 78-89 p.

Fishman, M.J., ed., 1993, Methods of analysis by the U.S. Geological Survey National Water Quality LaboratoryDetermination of inorganic and organic constituents in water and fluvial sediments: U.S. Geological Survey OpenFile Report 93-125, 217 p., http://pubs.er.usgs.gov/publication/ofr93125/.

Fishman, M.J., and Friedman, L.C., 1989, Methods for determination of inorganic substances in water and fluvial sediments: U.S. Geological Survey Techniques of WaterResources Investigations Report 05-A1, 545 p., https:// pubs.er.usgs.gov/publication/twri05A1.

Garbarino, J.R., Kanagy, L.K., and Cree, M.E., 2006, Determination of elements in natural-water, biota, sediment, and soil samples using collision/reaction cell inductively coupled plasma-mass spectrometry: U.S. Geological Survey Techniques and Methods, book 5, sec. B, chap. 1, 88 p., https:// pubs.usgs.gov/tm/2006/tm5b1/. 
Han, L.-F., and Plummer, L.N., 2013, Revision of Fontes \& Garnier's model for the initial ${ }^{14} \mathrm{C}$ content of dissolved inorganic carbon used in groundwater dating: Chemical Geology, v. 351, p. 105-114.

Han, L.-F., and Plummer, L.N., 2016, A review of singlesample-based models and other approaches for radiocarbon dating of dissolved inorganic carbon in groundwater: EarthScience Reviews, v. 152, p. 119-142.

Han, L.-F., Plummer, L.N., and Aggarwal, P., 2012, A graphical method to evaluate predominant geochemical processes occurring in groundwater systems for radiocarbon dating: Chemical Geology, v. 318-319, p. 88-112.

Helsel, D.R., 2012, Statistics for censored environmental data using Minitab and R (2d ed.): Hoboken, N.J., John Wiley \& Sons, Inc., 324 p.

Helsel, D.R., 2016, Calculating Uscores in R: Practical Stats web page, accessed January 9, 2017, at http://www.practicalstats.com/nada/downloads.html.

Helsel, D.R., and Lee, L.R., 2006, Analysis of environmental data with nondetects-Statistical methods for censored environmental data: American Statistical Association Joint Statistical Meeting continuing education workshop, Seattle, Wash.

Kalin, R.M., 1994, The hydrogeochemical evolution of the groundwater of the Tucson Basin with application to 3-dimensional groundwater flow modeling: University of Arizona, Ph.D. dissertation, $510 \mathrm{p}$.

Kayaci, H., 1997, Recharge estimation by the chloride mass balance method in the Tucson Basin: University of Arizona, M.S. thesis, $30 \mathrm{p}$.

Law, C.S., Watson, A.J., and Liddicoat, M.I., 1994, Automated vacuum analysis of sulfur hexafluoride in seawater-Derivation of the atmospheric trend (1979-1993) and potential as a transient tracer: Marine Chemistry, v. 48, p. 57-69.

Lee, Lopaka, 2015, Package "NADA", Nondetects and data analysis for environmental data, version 1.5-6: The Comprehensive R Archive Network web page, accessed December 12, 2016, at https://cran.r-project.org/web/packages/NADA/ NADA.pdf.

Lipman, P.W., 1993, Geologic map of the Tucson Mountains caldera, southern Arizona: U.S. Geological Survey Miscellaneous Investigations Series Map I-2205, scale 1:24,000.

National Institute of Standards and Technology, 2003, Addendum to certificates 2709 San Joaquin soil, 2710 Montana soil, 2711 Montana soil, of Leachable concentrations using US EPA method 3050 for flame atomic absorption spectrometry and inductively coupled plasma atomic emission spectrometry): Gaithersburg, Md., National Institute of Standards and Technology, 6 p.
National Park Service, 2010, Saguaro National Park Geologic resources inventory report: Natural Resource Report NPS/ NRPC/GRD/NRR-2010/233, 64 p., accessed August 16, 2017, at https://science.nature.nps.gov/im/units/sodn/assets/ docs/Inventories/Geo_Inv_SAGU.pdf.

Oksanen, J., Guillaume, Blanchet, F., Friendly, M., Kindt, R., Legendre, P., McGlinn, D., Minchin, P.R., O’Hara, R.B., Simpson, G.L., Solymos, P., Henry, M., Stevens, H., Szoecs, E., and Wagner, H., 2016, Package 'vegan'-Community Ecology package, version 2.4-1: The Comprehensive R Archive Network web page, accessed December 12, 2016, at https:// cran.r-project.org/web/packages/vegan/index.html.

Parkhurst, D.L., and Charlton, S.R., 2008, NetpathXL-An Excel interface to the program NETPATH: U.S. Geological Survey Techniques and Methods, book 6, chap. A26, 11 p.

Patton, C.J., and Kryskalla, J.R., 2011, Colorimetric determination of nitrate plus nitrite in water by enzymatic reduction, automated discrete analyzer methods: U.S. Geological Survey Techniques and Methods, book 5, chap. B8, 34 p., http://pubs.usgs.gov/tm/05b08/.

Plumlee, G.S., and Nash T.J., 1996, Geoenvironmental models of mineral deposits—Fundamentals and applications, in duBray, E.A., ed, Preliminary compilation of descriptive geoenvironmental mineral deposit models: U.S. Geological Survey Open-File Report 95-0831, https://pubs.usgs.gov/ of/1995/ofr-95-0831/.

Plummer, L.N., Bohlke, J.K., and Doughten, M.W., 2006, Perchlorate in Pleistocene and Holocene groundwater in north-central New Mexico: Environmental Science and Technology, v. 40, p. 1757-1763, https://doi.org/10.1021/ es051739h.

Plummer, L.N., Bexfield, L.M., Anderholm, S.K., Sanford, W.E., and Busenberg E., 2012, Geochemical characterization of ground-water flow in the Santa Fe group aquifer system, Middle Rio Grande Basin, New Mexico, Version 1.2, U.S. Geological Survey Water-Resources Investigations Report 03-4131, 395 p.

R Core Team, 2015, R-A language and environment for statistical computing: R Foundation for Statistical Computing, Vienna, Austria, accessed December 12, 2016, at https://www.r-project.org/.

Révész, Kinga, and Coplen, T.B., 2008a, Determination of the $\delta\left({ }^{2} \mathrm{H} /{ }^{1} \mathrm{H}\right)$ of water—RSIL lab code 1574: U.S. Geological Survey Techniques and Methods 10-C1, 27 p., http://pubs. usgs.gov/tm/2007/tm10c1/.

Révész, Kinga, and Coplen, T.B., 2008b, Determination of the $\delta\left({ }^{18} \mathrm{O} /{ }^{16} \mathrm{O}\right)$ of water-RSIL lab code 489: U.S. Geological Survey Techniques and Methods 10-C2, 28 p., http://pubs. usgs.gov/tm/2007/tm10c2/. 
Révész, Kinga, Qi, Haiping, and Coplen, T.B., 2012, Determination of the $\delta^{34} S$ of sulfate in water; RSIL lab code 1951, chap. 10 of Stable isotope-ratio methods, sec. C of Révész, Kinga, and Coplen, T.B. eds., Methods of the Reston Stable Isotope Laboratory (slightly revised from version 1.1 released in 2007): U.S. Geological Survey Techniques and Methods, book 10, 33 p., https://pubs.usgs.gov/tm/2006/ tm10c10/. (Supersedes versions 1.0 and 1.1 released in 2006 and 2007, respectively.)

Smith, D.B., 1995, United States Geological Survey Certificate of Analysis, Cody Shale, SCo-1, accessed August 14, 2017, at https://crustal.usgs.gov/geochemical_reference _ standards/codyshale.html.

Smith, K.S., and Huyck, H.L.O, 1999, An overview of the abundance, relative mobility, bioavailability, and human toxicity of metals, in Plumlee, G.S., and Logsdon, M.J., eds., The environmental geochemistry of mineral deposits, Part A-Processes, techniques, and health issues: Reviews in Economic Geology, v. 6, p. 29-70.

Smith, L.J.D., Ptacek, C.J., Blowes, D.W., Groza, L.G., and Moncur, M.C., 2015, Perchlorate in lake water from an operating diamond mine: Environmental Science and Technology, v. 49, no. 13, p. 7589-7596, accessed June 21, 2017, at http://pubs.acs.org/doi/abs/10.1021/acs.est.5b01111.

URS Corporation, 2012, Engineering evaluation/cost analysis (EE/CA), Old Yuma Mine Saguaro National Park, Tucson, AZ: URS Corporation, 66 p.

U.S. Environmental Protection Agency, 1994, Synthetic precipitation leaching procedure, Method 1312: U.S. Environmental Protection Agency 30 p., accessed June 29, 2017, at https://www.epa.gov/sites/production/files/2015-12/ documents/1312.pdf.

U.S. Environmental Protection Agency, 2000, National water quality inventory-1998 report to Congress: U.S. Environmental Protection Agency Report EPA-841-F-00-006, 45 p., accessed January 23, 2017, https://www.epa.gov/ waterdata/1998-national-water-quality-inventory-reportcongress.

U.S. Environmental Protection Agency, 2008, Interim drinking water health advisory for perchlorate: U.S. Environmental Protection Agency Report EPA 822-R-0825, 49 p., accessed June 28, 2017, at https://www.epa.gov/ dwstandardsregulations/perchlorate-drinking-water.
U.S. Environmental Protection Agency, 2017a, Drinking water contaminants: U.S. Environmental Protection Agency database, accessed March 21, 2017, at https://www.epa. gov/ground-water-and-drinking-water/national-primarydrinking-water-regulations.

U.S. Environmental Protection Agency, 2017b, Regional screening level (RSL) composite worker soil table, accessed July 3, 2017, at https://semspub.epa.gov/work/03/2245069. pdf.

U.S. Geological Survey, variously dated, National field manual for the collection of water-quality data: U.S. Geological Survey Techniques and Methods for Water-Resources Investigations, book 9, chaps. A1-A10, accessed January 23, 2017, at http://pubs.water.usgs.gov/twri9A.

U.S. Geological Survey, 2013, Analytical contract laboratory method summaries [methods 8,10 , and 19], accessed January 23, 2017, at http://minerals.cr.usgs.gov/projects/ analytical_chem/references.html.

U.S. Geological Survey, 2017a, The Reston Groundwater Dating Laboratory, accessed August 8, 2017, at https://water. usgs.gov/lab/.

U.S. Geological Survey, 2017b, National Water Information System-Web interface, accessed March 16, 2017, at http:// dx.doi.org/10.5066/F7P55KJN.

Wilson, W.E., and Schlepp, G., 2008, Old Yuma Mine, Pima County, Arizona, in Staebler, G.A., and Wilson, W.E., 2008, American Mineral Treasures: East Hampton, Conn., Lithographie, LLC, p. 240-247.

Wilson, S.A., 1998a, U.S. Geological Survey certificate of analysis, andesite AGV-2, 3 p., accessed August 14, 2017, at https://crustal.usgs.gov/geochemical_reference_standards/ pdfs/andesite2.pdf.

Wilson, S.A., 1998b, U.S. Geological Survey certificate of analysis, granodiorite, Silver Plume, Colorado, GSP-2, 3 p., accessed August 14, 2017, at https://crustal.usgs.gov/geochemical_reference_standards/pdfs/grano.pdf.

Wilson, S.A., 2001, United States Geological Survey certificate of analysis, Green River shale, SGR-1, 3 p., accessed August 14, 2017, at http://crustal.usgs.gov/geochemical_ reference_standards/pdfs/shale.pdf. 


\section{Appendix A. Groundwater sample data from Old Yuma Mine study area.}

Appendix A is available as an Excel table and may be downloaded from https://doi.org/10.3133/sir20185019. 
Menlo Park and Lafayette Publishing Service Centers Manuscript approved January 29, 2018

Edited by Monica Erdman

Design and layout by James E. Banton 


\section{$\frac{\mathbb{3}}{3}$}

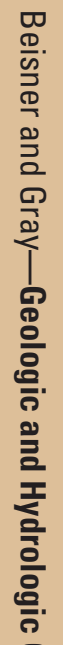

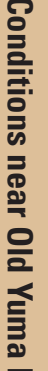

胥

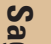

要

童.

旁

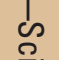

言

产

.

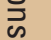

疋

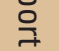

$\widetilde{\widetilde{\omega}}$

잉 